\title{
DE GROEP NOORD- EN ZUID-PAGEH VAN DE MENTA WEI-EILANDEN.
}

\author{
Ethnografische beschrijving (met kaart on illustraties).
}

Door J. F. K. HANSEN.

Gedurende een tiental maanden (Augustus 1911-April 1912) mocht ik het voorrecht hebben, commandant te zijn van het op de Pageh-eilanden gelegerd detachement der marechausséecompagnie, met de opdracht, aldaar ook civiele bestuurszaken te regelen. Ik werd daardoor in de gelegenheid gesteld kennis te maken met de eilandenbewoners, tot zekere hoogte, met dat primitieve volk mede te leven, en het te leeren begrijpen.

Slechts eenmaal zette ik voet aan wal op de andere eilanden van den Mentawei-archipel (Siberoet en Sipora); ik wil mij derhalve niet vermeten, iets over die eilanden neer te schrijven en bepaal mij dus tot de Pageh-eilanden.

Wegens den betrekkelijk korten tijd, dien ik daar vertoefde, terwijl ik mijne geregelde dienstbezigheden had, die mij niet veel tijd lieten tot ernstige studie van taal, land en volk, kan mijn werk allerminst aanspraak maken op volledigheid. Ik heb echter zoo veel mogelijk naar nauwkeurigheid gestreefd.

Over de Mentawei-eilanden is reeds veel geschreven; doch bij mijn weten is in 't bijzonder over de Pageh-eilanden nog niets gepubliceerd, en het komt $\mathrm{mij}$ in alle bescheidenheid voor dat mijne mededeelingen eenig nieuws brengen en enkele nieuwe gezichtspunten openen.

Dankbar erwähne ich der liebenswürdigen Hilfe des ehrwürden Herrn Börger, Missionar auf den Pageh-Inseln. Seiner Förderung verdanke ich manche Mitteilungen über die Sitten den Mentawaier und einige Lieder, wie dieselbe auf den Missionsschulen gesungen werden.

Dl. 70 


\section{HOOFDSTUK I.}

Geographie, klimaat, bodemgesteldheid, fauna, flora en pomona.

Geographie. Bewesten Sumatra bevindt zich een reeks eilanden en eilanden-groepen (t.w. Simoloer, Nias, Batoe-eilanden, Mentawei-eilanden en Engano), die, wat bodemgesteldheid, flora en fauna betreft, het vermoeden wettigen, dat deze gronden vroeger één zijn geweest met Sumatra. De algemeene lengterichting dier eilanden is ongeveer evenwijdig aan het Barisangebergte op Sumatra; dit eiland is vermoedelijk vroeger een tweede vulkaangebergte rijk geweest, waarvan bedoelde eilandenreeks dan een overblijfsel is.

Een onderdeel van deze reeks vormen de Mentawei-eilanden, zich uitstrekkende tusschen $98^{\circ}-100^{\circ} \mathrm{O}$. L. en $1^{\circ}-3^{\circ} \mathrm{Z}$. B. Talrijke minder belangrijke kleinere eilandjes uitzonderende, is deze archipel te verdeelen in het eiland Siberoet, Sipora en de Pageh-eilanden (ook Nassau-eilanden genoemd). Laatsgenoemde bestaan uit Noord-Pageh en Zuid-Pageh, welke eilanden in vroeger tijd zeer waarschijnlijk één geheel vormden, blijkende niet alleen uit de geologische overeenstemming, doch ook uit een volksverhaal dienaangaande.

De oppervlakte van Noord- en van Zuid-Pageh bedraagt respectievelijk \pm 680 K.M ${ }^{2}$. en \pm 1030 K.M. ${ }^{2}$.

Noord-Pageh wordt in het Noorden van het eiland Sipora (middelste eiland van de Mentawei-groep) gescheiden door straat Sipora, een veilig vaarwater ter breedte van 6 à 7 zeemijl, dat alleen ter hoogte van hoek Marlborough (Sipora) gevaarlijke ondiepten biedt; deze zijn echter te vermijden door het midden van de straat te houden.

De Indische Oceaan vormt beoosten de Pageh-eilanden en bewesten Sumatra's vasten wal een goed, meestal rustig vaarwater, terwijl dezelfde wereldzee bij voortduring de Westelijke kusten beukt, die, als wilden zij zich pantseren tegen dat ruwe geweld, op verscheidene plaatsen een rotsvorming hebben, waartegen de oceaanbranding bulderend, doch machteloos uiteenspat. Het woeste spel der baren kluistert de Westelijke eilandenbewoners vele maanden des jaars aan hunne kampongs, in dien zin, dat zij met hunne onzeewaardige vaartuigen niet 
vermogen uit te varen, ook al ware het om dicht langs de kust te houden.

Ook in het Zuiden hebben de Pageh-eilanden den Indischen Oceaan tot begrenzing.

De eilanden Noord- en Zuid-Pageh worden gescheiden door de straat Sikakap. Deze straat, ongeveer 7 zeemijlen lang, vormt een breed en diep vaarwater, waarin soms wel hinderlijke stroomen doorstaan, doch dat te allen tijde zelfs door de diepstgaande schepen bevaren kan worden. Slechts zelden komt het voor, dat de inbourlingen zich met hunne ranke vaartuigjes niet in deze straat durven wagen. De Oostelijke ingang van straat Sikakap is een geschikte ankerplaats. Vau daar meet men 105 zeemijlen tot Padang.

De geheele Mentawei-groep beslaat, inclusief de tusschen de eilanden gelegen straten, een lengte van \pm 190 zeemijlen. (342 K.M.) Van Zuid naar Noord, bestaat de groep uit de volgende eilanden en straten: Pageh-eilanden, straat Sipora, Sikobo of Sipora, Zeebloemstraat, Siberoet, straat Siberoet. De Zeebloem-straat en straat Siberoet hebben nog al gestreden om den voorrang als Westelijke toegangsweg tot Padang. Eerstgenoemde is geheel veilig en schoon, doch biedt nagenoeg geen ankergrond. Toch werd vroeger deze route verkozen boven de straat Siberoet, die weliswaar bij tegentij goeden ankergrond en veilige ligplaatsen bood (op de Noord-kust van Siberoet), doch niet schoon was van riffen. Tegenwoordig echter is de ligging dier riffen met zorg en nauwkeurigheid op de zeekaarten aangegeven, en is straat Siberoet de aangewezen Westelijke doorvaart. De transatlantische lijnen en de Paketvaartbooten maken dan ook van deze passage gebruik. De scheepsroute tusschen Padang en Batavia gaat door het vaarwater beoosten de Mentawei-eilanden, hetwelk een maximum breedte heeft van \pm 50 zeemijlen. De ligging ten opzichte van het scheepvaartverkeer kan dus zeer gunstig genoemd worden, een factor van waarde, wanneer wellicht straks impulsieve krachten zullen pogen, deze eilanden tot economischen bloei te brengen.

Ons weer tot de Pageh-eilanden bepalende, vinden we op Zuid-Pageh, van Zuid naar Noord gaande, in de eerste plaats de Veeckensbaai, een groote ruime baai, die, afgesloten als zij in het Oosten is door het eiland Tinōpo, een veilige ligplaats voor schepen vormt. De ankergrond is goed, terwijl de diepte 
nagenoeg overal voldoende is voor de grootste schepen (op sommige plaatsen zelfs 25 vadem).

Ongeveer 4 zeemijlen Noordelijker op Zuid-Pageh's Oostkust treft men de baai van Laboean Djaoe of Labadjaoe aan, die, vrij goed beschut, tot dicht bij den wal nog een goeden ankergrond geeft in ruim 10 vadem water. Verder Noordelijk langs de Oostkust gaande, vindt men geen baaien of natuurlijke havens van beteekenis, zeer zeker niet voor de groote scheepvaart. Weliswaar bedraagt de zeediepte tot kort onder den wal bijna doorloopend 14 à 15 vadem en zou men hier en daar op de reede gevoegelijk kunnen ankeren, doch bij doorstaande $\mathrm{O}$. winden zou men elke beschutting missen. Bovendien maken vele riffen de vaart onveilig.

Baaien en ankerplaatsen op de Westkust van Zuid-Pageh kunnen buiten beschouwing blijven, daar deze kust geen enkele beschutting biedt tegen de branding van den Indischen Oceaan.

Reeds is vermeld, dat in straat Sikakap een goede ankerplaats gevonden wordt aan den Oostelijken ingang. Die ankerplaats ( 115 vadem diep) ligt even bewesten het eilandje Tongo of Bakat Binoeang, dat dwars voor den ingang ligt. Hier is de meest gebruikelijke ankerplaats voor de schepen, die de Pageheilanden aandoen, aangezien ze zich bevindt juist tegenover het plaatsje Sawang Toengkoe (Zuidoostkust van Noord-Pageh), waar de zetel van ons bestuur is gevestigd. Langs de Oostkust van Noord-Pageh treft men geen ankerplaatsen van belang aan, of het zouden (voor de kleine scheepvaart) moeten zijn de reeden van Saoemanganja en van Simangandjo, waar men onbeschut op geruimen afstand van de kust moet ankeren. In- en ontschepen veroorzaken hier echter veel last, aangezien men met kleine prauwtjes zich door de rollers en zandplaten moet heenwerken.

Hiervoren werd reeds met een enkel woord gewag gemaakt van de onherbergzaamheid van de Westkust der beide eilanden. Men zou hier ook geenerlei ankerplaats verwachten, ware het niet, dat de Silaboe of Silaboelaboe-baai hierop een gunstige uitzondering maakt. Deze baai wordt in het Westen volkomen beschut door de eilanden Montrado en Mangkassar, bij de bevolking bekend onder de namen Silaboe mabeoe en Silaboe magossok (groot- en klein Silaboe). Even benoorden Mangkassar ankert men veilig en beschut in 10 vadem water. De Noordelijke toegang tot de baai, n.l. tusschen Montrado en den vasten wal, 
is te verkiezen boven den Zuidelijken toegang, daar hij zoo goed als koraalvrij is en groote diepten (10-17 vadem) bezit.

In verband met de betere beschutting, die de Oostkust der Pageh-eilanden heeft, treft men de meeste kampongs aan op het Oostelijk gedeelte der eilanden, en concentreert zich ook de scheepvaart der inboorlingen in hoofdzaak aan de Oostkust, waar het water steeds, zelfs met kleine prauwtjes, bevaarbaar is; uit de Westelijke kampongs is het dikwijls kwaad uitvaren. Karakteristiek te dezen opzichte is de naam van een kampong op de Zuidwestkust van Noord-Pageh, Betoe Monga geheeten. Betoe beteekent in de Mentaweische taal: schuim, rook of damp; monga beteekent riviermond, zoodat bedoelde naam aangeeft, dat op de kust steeds felle branding staat.

Op ongeveer 14 zeemijlen in Zuidoostelijke strekking van de Zuidpunt van Zuid-Pageh bevindt zich het eilandje Sandion of Sanding, mede tot de Pageh-eilanden behoorende. Meestentijds is dit eilandje, dat met Europeesch kapitaal in cultuur gebracht is (klappers) wegens de branding niet door de kleine inlandsche vaartuigen te bereiken. Marsden ${ }^{1}$ vermeldt, dat hier in 1769 een bezetting gelegen zou hebben van eenige soldaten onder commanda van een officier, doch dat die bezetting binnen 't jaar weer verdwenen was.

Een groot aantal kleinere eilandjes behoort verder nog tot de Pageh-groep. $\mathrm{Zijn}$ al de meeste daarvan zeer vruchtbaar en beplant met klappers, toch zijn ze zóó gering van oppervlakte, dat het meerendeel niets eens bij name bekend is. De meest bekende eilandjes zijn, in en vóór de straat Sikakap:

P. Sigoegoelet (P. Sama), 2

P. Sidjau (P. Ketjil),

P. Bakat Binoeang (P. Tongo),

P. Sibaboet,

P. Bakat Peigoe,

P. Masoesoe (P. Mashoegoe),

P. Loemoen (P. Roemoen),

P. Ragi (P. Lagi),

P. Roesoe (P. Teh Noesa),

I W. Marden: „History of Sumatra”. London, 1811. Blz. 468.

${ }^{2}$ P. = Poelau (eiland). De namen, tusschen haakjes aangegeven, zijn die, welke op de meeste kaarten voorkomen, doch minder bekend zijn bij de Mentaweische bevolking of zeevarende Maleiers. 
P. Siopa mabeoe (P. Siopa běsar),

P. Siopa magossok (P. Tiopa kětjil),

Op de Westkust van Noord-Pageh, de reeds genoemde eilanden:

P. Silaboe mabeoe (P. Montrado),

P. Silaboe magossok (P. Mangkassar),

Op de Westkust van Zuid-Pageh:

de Sibaroe-baroe-eilanden.

Vóór en in de Veeckensbaai '

P. Monga,

P. Soema,

P. Tinopo,

P. Messingani,

Johan-Maria-eiland,

Sterk-eilanden,

Palm E.

Nassau E.

Neumann E.

Maes E.

van Diemensland,

Verdam E.

Verder Noordelijk, ter hoogte van Labadjaoe:

P: Sikinia.

Zooals reeds vermeld, zijn de eilanden Noord- en Zuid-Pageh van vulkanischen oorsprong; de kleinere eilanden daarentegen zijn door koraalvorming ontstaan.

K 1 imaat. Het klimaat op de Pageh-eilanden is vochtig; van een nat en droog jaargetijde kan men niet spreken; men heeft er bijna dagelijks regen. In het algemeen heerscht er van November tot Mei de Noordwest-, van Mei tot November de Zuidoostmoesson. In de maanden Maart en April heeft men enkele zeer zware regenbuien, die uit het Westen komen aandrijven, dikwijls zonder dat ze met wind gepaard gaan. In den tijd van den Zuidoostmoeson heerschen er dikwijls N. W. en W. winden, die vele en zware regens aanbrengen. Ook O. en Z.O. winden brengen dikwijls regen, soms gepaard met onweer. Boven

1 De meeste dezer eilanden zijn genoemd naar zeevaarders, ontdekkersreizigers, e. d. g. Ze zijn onder die benaming bij de bevolking natuurlijk niet bekend. 
den vasten wal van Sumatra kan men soms onweersbuien zich zien samenpakken, die bij het doorkomen van den landwind zeewaarts drijven. Meestal bereiken zij de eilanden niet, doch zijn vóór dien tijd opgelost. Een machtig schouwspel is het, wanneer men 's avonds of 's nachts het hemelvuur ziet flitsen boven Sumatra's Westkust; niets belemmert den vrijen blik over den Oceaan, men ziet het inktzwarte uitspansel als 't ware ieder oogenblik stukgereten door vuurstralen. En buitengewoon snel volgen de bliksemstralen elkander op, voor het gezicht veel sneller, dan wanneer men zelf op of dicht bij de plaats van een onweder bevindt.

Zooals reeds gezegd is, brengen W. en N. W. winden veelal regen mede. Doch dikwijls bereiken die buien de Oostkust niet, doordat zij zich geheel ontlasten boven het zware geboomte, èn op de Westkust, èn in het hart van de eilanden. Omgekeerd komen ook de regenbrengende O. en Z.O. winden meermalen geheel droog op de Westkust aan. W. en O. winden hebben meestal hun kracht verloren, eer ze de Oost- of Westkust bereikt hebben. Vandaar dat men soms veilig langs de Oostkust kan varen, terwijl het op de Westkust spookt, en omgekeerd.

Door deze omstandigheden verklaart zich het klimatologisch verschil tusschen Oost en West. De temperatuursverschillen zijn soms opmerkelijk groot.

Noord- en Zuid-Pageh zijn zwaar bedekt door oerwoud, dat ruim voedsel vindt in de humus-kleilaag. Met zulk eene bodembekleeding is het geen wonder, dat men bijna dagelijks regen heeft. Van een eenigszins aanhoudende droogte is nooit sprake.

Over het algemeen kan het klimaat gelijkmatig genoemd worden; al te hooge temperatuur wordt spoedig getemperd door neerslag. Gezond is het hier echter niet; korallinische werkingen en bij jonge landvorming te voorschijn tredende miasmen dragen niet bij tot de gezondheid van het klimaat. Daar koraalvorming en kustwijziging het meest op de Oostkust voorkomen, is het daar ook ongezonder dan op de Westkust.

Werd hierboven bij de weersgesteldheid melding gemaakt van regen, onweder en wind, ook mooi weder heeft men dikwijls te wachten. Bij fraai en helder weer, wanneer de lucht ijl is, onderscheidt men, van de Oostkust af, zeer duidelijk Sumatra's vasten wal. Bijna dagelijks, zeer vroeg in den morgen, kan men genieten van het machtige schouwspel, de zon in purperen 
pracht zich langzaam en statig verheffend boven de hooge bergen van Sumatra's Westkust. Wanneer de zon hooger aan de kim komt, doezelt het berglandschap weg, en ziet men vóór zich niets meer dan zee en lucht. Bij zeer helder weer kan men echter Sumatra's vasten wal nog tot den middag blijven onderscheiden.

Van geschikte, uitzichtvrije punten op de Noordoost- en Noordkust van Noord-Pageh kan men bij helder weer evenzoo de ligging van het eiland Sipora onderscheiden.

Kalm en helder weer bij volle maan verhoogt ook 's avonds en 's nachts het natuurschoon. Dan liggen de eilanden, met hun machtige vegetatie, gedrenkt in een zilver lichtbad, zachtjes kaatsen de palmen aan het strand het maanlicht terug; van de zee, waaruit koraalriffen hier en daar zwart opstippen, ruischt zacht een wonderlijk lied, en milliarden sterren aan het uitspansel schijnen even zoovele oogen te zijn, die nieuwsgierig de zich in het licht badende eilanden begluren. Is het wonder, dat zoo'n natuurtafereel op den eenvoudigen vreesachtig-bijgeloovigen Mentaweier een indruk maakt van geestenmacht?

Bodemgesteldheid. De kusten - in het bijzonder de Oostkust - vertoonen alluviale gronden of wijzen op korallinischen oorsprong. In het Oosten, het Noordoosten en het Zuidoosten heeft men strandvlakten van eenige beteekenis. Alles duidt daar op jonge landvorming, niet het minst in baaien en inhammen. Daar treft men de karakteristieke strandvegetatie aan, rizophoren en casuarinen. Bij het naderen van die kusten zijn baaien, inhammen en riviermonden bijna niet te onderscheiden, zóó weinig steekt hun groen af tegen de bosschen van het hooger gelegen binnenland. De inboorlingen en enkele geoefende Maleische zeevaarders weten met bewonderenswaardige nauwkeurigheid reeds op grooten afstand de riviermonden te onderscheiden, die zij met hunne kleine vaartuigen moeten binnen stevenen.

De Westkust heeft over het algemeen rotsvorming; koraalriffen zijn hier eehter niet zeldzaam.

Beide hoofdeilanden zijn heuvelachtig, de grootste hoogte bedraagt echter niet meer dan $250 \mathrm{M}$. De laaglanden langs de kust staan bloot aan overstrooming door vloed. Evenzoo maakt de benedenloop der groote rivieren met overstrooming (banjir) kennis. Hoe sterk de aan- en afslibbing door de zee is, blijkt 
uit het feit, dat op Noord-Pageh's Oostkust, ter hoogte van kampong Matobe, zich een kale zandplaat bevindt, die de oudste bewoners zich nog herinneren als een wel begroeid eilandje, waar zelfs zeilschepen ten anker kwamen. Waar de kust koraalvormig is, en zich, op eenigen afstand van de kust, koraalriffen bevinden, daar is bij helder weer het water tot groote diepte doorzichtig. Daar ziet men dan de schoone zeetuinen, koraalbloemen en koraaldieren in allerlei grootten en in de meest verscheidene kleuren en grillige vormen. In dat water dartelen visschen rond in ongekende kleurenpracht, visschen, die in teekening en kleur niet onderdoen voor de fraaiste siervogels. Het gedartel van dit kleurrijke volkje wordt nu en dan plotseling wreed verstoord door een roofvisch, die met woeste snelheid door en over het water schiet en soms groote sprongen boven boven water doet, om zijn prooi te bereiken. Van de koraalriffen - door onze zeelui gemeenlijk "steentjes» genoemd ' loert ook hier en daar een zeevogel of steltlooper op een vischbuit.

Slechts op enkele plaatsen naderen moerasgedeelten de kust. De meeste groote moerassen vindt men op korten afstand van de kust, hetgeen aanleiding geeft tot de veronderstelling, dat op die plaatsen de vroegere kustlijn geloopen moet hebben, en dat door onvolledige aanslibbing die gedeelten niet geheel gevuld zijn, terwijl daarbuiten de aanslibbing haar geregeld verloop nam, en daar een nieuwe kustlijn werd gevormd.

Hoewel het benedenstroomgebied der groote rivieren - voorzoover ze daar ter plaatse lage en vlakke oevers hebben - aan bandjir onderhevig is, treft men daar toch weinig moerassen aan. Het bandjirwater loopt weer vrij volledig weg, een vruchtbare sliblaag achterlatende. In het algemeen strekken zich de moerassen evenwijdig aan de kustlijn uit.

De bovenloop der groote rivieren gaat door rots- en heuvelterrein, terwijl bij middel- en benedenloop de bedding diep is ingesneden in ladang- ${ }^{2}$ of boschterrein.

Een tocht langs een der groote rivieren loont zeer de moeite. Wat de natuur daar voor schoons biedt, laat een machtigen indruk op ons achter. We nemen voor zoo'n tocht plaats in

${ }^{1}$ Aan de steentjes ruiken (scheepsterm) = vastloopen op, of schuren langs koraal- of rotsgrond.

2 Bouwveld. 
een inlandsch vaartuigje, $a b a k$ genoemd, dat bestaat uit een uitgeholden boomstam, zonder meer. Zitplaatsen zijn er niet, de Mentaweier hurkt neer in zijn bootje, op de knieën liggend, de beenen samengevouwen. Of wel hij neemt een zittende houding aan op den bodem van de prauw, die altijd een laagje water bevat, hetzij door regen, roeispatten of overgeslagen golven. Hindert dit den naaktgaanden Mentaweier niet, wij wapenen ons met een plankje, een kistje, een stuk pisangstam of iets dergelijks, om daarmede een zitbankje te improviseeren. De rĕpaks of vlerken zijn aangebonden, want zonder die zouden we, weinig bedreven als we zijn in de kunst om het evenwicht te houden in zoo'n schommelend bootje, al spoedig een onaangename draaibeweging maken om de lengteas van de abak, en aldus een onvrijwillig bad nemen. Wegens die ver zijwaarts uitstekende vlerken kan de prauw slechts met den steven den oever aandoen, derhalve moet eerst de stuurman instijgen, daarna 1 of 2 roeiers, dan wij, en vervolgens weer een paar roeiers. Ons galjoen is nu bemand; met de loega (pagaai) wordt het van wal gestooten, en de reis begint. We gaan stroomopwaarts. Met regelmatige slagen pagaaien de roeiers voort, terwijl de stuurman, achterin gezeten, slechts voorzien van een pagaai, ons nauwkeurig in het goede vaarwater houdt, en de boot op duimbreedte af daarheen stuurt, waarheen hij wenscht. De zeer groote prauwen zijn soms voorzien van iets wat op een roer lijkt, doch als regel bestuurt de Mentaweier zijn prauw met een pagaai. We zijn nu in den benedenloop van de rivier; links en rechts zien we vrij hooge en steile oevers, zwaar begroeid. Hier en daar sijpelt het zakwater van den boschgrond door de steile oevers heen. Al het geboomte is vegetatie van oerwoud, doch naarmate we verder stroomopwaarts komen, verschijnt een enkele sagopalm wiens gedeeltelijk aardvrije wortels rood getint zijn.

In het water liggen cylinderblokken van sagostammen op sommige plaatsen aan den oever of aan een stok verankerd. De aan stukken gehakte sagostam wordt n.l. door den Mentaweiers geweekt in de rivier, om er later gemakkelijk het merg uit te kunnen verwijderen. Hier en daar zijn het hooge riet en de struiken aan den rivieroever neergedrukt en platgetrapt, een bewijs, dat daar prauwen worden gemeerd, en dat er van die plaats een pad loopt naar een kampong of een ladang. Langzaam 
naderen we dus bewoonde streken, hetgeen tevens blijkt uit van verre waarneembaar hanengekraai. Bamboestoelen, die verder aan den benedenloop ongerept tierden, vertoonen hier nu en dan een afgekapten stengel. Plotseling, bij het nemen van een rivierbocht, komt ons een prauwtje tegemoet met twee Mentaweische vrouwen en een knaapje. Nauwelijks hebben dezen ons bespeurd, of de ongewone aanblik van Europeanen brengt een wilden schrik over hen. De beide vrouwen laten zich overboord vallen, zwemmen en waden naar den oever en verdwijnen in het bosch. De kleine knaap laat zich voorover in de prauw vallen, en drukt zijn neus tegen den bodem. Op het herhaald geruststellend geroep van onze roeiers, waagt de knaap het, zich op te richten, grijpt een roeispaan, en stuurt naar de plaats, waar de beide vrouwen den oever beklommen hebben. Wij roeien verder. Eenige oogenblikken later hooren we de schelle roepstem van het jongetje in het bosch klinken. Kort daarop volgt antwoordend geroep. De paniek-menschjes hebben elkaar dus weer gevonden. Verder gaande, bemerken we dat de oevers niet meer zoo zwaar begroeid zijn; enkele groote open plekken vertoonen zich, waarvan de beplanting verraadt, dat zich dicht hierbij ladangs moeten bevinden. Ook worden de oevers lager, en op sommige planten zien we een prauwenloods, half verscholen tusschen het groen. We vermoeden dicht bij een kampong te zijn, doch we moeten nog geruimen tijd geduld oefenen. Eindelijk, bij gindsche bocht, welft zich een houten loopbrug over de rivier. Na onder de brug doorgevaren te zijn, zien we een kampong. De oever is aan die zijde afgegraven, of heeft zijne natuurlijk flauwe helling, zoodat er een slibberige strook grond ontstaan is. Op die strook zijn een aantal prauwen op het droge getrokken. We varen de kampong voorbij, het midden van de rivier houdende. De oevers worden geleidelijk lager, en vergunnen ons een blik te werpen op het land links en rechts. Bosch en ladangterrein wisselen elkaar af, ook zien we hier en daar kleine grasvlakten en in de rivier passeeren we enkele eilandjes. Het rivierwater, dat in den benedenloop bruin-troebel was, begint nu helder te worden, ook de diepte neemt af, en we zijn soms in staat, den rivierbodem te zien. We gaan den bovenloop tegemoet, op enkele plaatsen raken de roeispanen reeds den rivierbodem. Ook is de breedte van de rivier anmerkelijk afgenomen, zandplaten en 
eilandjes maken het varen steeds bezwaarlijker, de kiel schuift nu en dan over het zand en het bootje moet getrokken worden. Dan krijgen we weer voldoende diep water om te roeien, doch veelvuldiger worden de keeren, dat de boot getrokken en geduwd moet worden, zelfs moeten we ook wel eens in het water stappen, om mee te duwen. We hebben nu gelegenheid, om de leisteen- en conglomeraatformatie van den bodem waartenemen. Hier en dąar visschen we een stuk bruinkool uit het water op. Langzamerhand versperren groote steenblokken ons den weg, en passeeren we kleine zijtakken van de rivier. Roeien is niet meer mogelijk; de tocht naar den bovenloop moet verder te voet plaats hebben. We hebben nu gelegenheid, het oerwoud met zijn reuzeboomen, van nabij te bezien. In de verte schreeuwen eenige apen, aan den zoom van het bosch vertoonen zich hertensporen, en in het water zien we groote visschen ons voorbijschieten. Een eind verder komt de rivier langs een rotspartij naar omlaag, en vormt daar een schilderachtigen waterval. De rivierbedding is hier ruim voorzien van klei-lei. We hebben nu voldoende van de rivier, hare oevers en hare beddings gezien, en keeren naar huis terug.

Tijdens dit uitstapje hebben we reeds een vluchtige blik geworpen op bodem en terrein. Het binnenland is van vulkanischen oorsprong, het vormt een hoogland met enkele toppen van onbeduidende hoogte (maximum \pm 250 M.) Op Zuid-Pageh heeft men een heuvelrug, zich uitstrekkende in de lengterichting van het eiland, en een waterscheiding vormende tusschen de Oostelijke en Westelijke rivieren. Deze heuvelrug heeft naar de Oostkust enkele uitloopers met een soort kalksteenformatie. Op Noord-Pageh gaan enkele rivieren in haar benedenloop over grooten afstand door leisteenlagen. In sommige kiezellagen komt veel glimmer voor, terwijl kalk- en kleimergel ook veelvuldig gevonden worden. Verschillende kleine stroombeddingen zijn vindplaatsen van kleilei.

Het binnenland is nagenoeg geheel bedekt met zwaar geboomte, en bezit bijzonder rijke humus- en kleilagen.

Fauna. De dierenwereld is zoo goed als dezelfde als die van Sumatra, doch van de groote land-dieren komt alleen het hert voor. Zelfs missen we er de grootere huisdieren: paarden, koeien, karbouwen, schapen en geiten. Hierop maken de 
bescheiden veekralen van de militaire bezetting en van enkele Maleiers eene uitzondering. Het ligt voor de hand, dat na de afscheiding van Sumatra, de Mentawei-eilanden oorspronkelijk ook de groote diersoorten bezaten. Onderlingen strijd en strijd met den mensch hebben ze uitgeroeid. Hoe echter het verdwijnen der groote huisdieren te verklaren? Men zou gaan betwijfelen, of ze er ooit geweest zijn, vooral als men weet, dat elk motief dienaangaande in de Mentaweische ornamentiek ontbreekt. Bij de Menangkabauers zoowel als bij de Batakvolken vindt men b.v. den karbouwhoren veelvuldig in de ornamentiek terug; bij de Mentaweiers geen spoor daarvan.

Wilde varkens komen op de Mentawei-eilanden niet voor, wel tamme. De honden vertoonen eenige afwijking van het algemeen over den Indischen archipel verbreide hondenras. Niet zoozeer wat bouw betreft, als wel hunne eigenschappen. Zoo hoort men den Mentaweischen hond zelden of nooit blaffen, enkele brom- of janktonen mogen althans dien naam niet dragen. Verder is elke hond een geboren jachthond. Niet het minste wordt gedaan ter africhting en toch munten ze alle op jacht uit. Wat voor verdienstelijke speurders die honden zijn, blijkt uit het volgende. Van de Veekraal eener militare bezetting waren 2 runderen het bosch in gevlucht. Weken lang werd door patrouilles en door bevolking naar die dieren gezocht; alles te vergeefs. Tot op zekeren dag een sergeant met een patrouille in een kampong kwam, daar eenige honden vroeg, en met hen toog naar een plaats in het bosch, waar hij sporen van de runderen gevonden had. Nauwelijks hadden de honden die sporen geroken, of ze gingen zoeken en snuffelen, en binnen het half uur waren de beide runderen gevonden, of liever..... hunne cadavers, reeds 8 dagen oud. Zelfs voor onze politiehonden zou het een zware tak zijn, een spoor van minstens 8 dagen oud op zóó vlotte wijze uit te werken!

Apen komen in 3 soorten voor: de sitc̀oet, de klapperaap, de atta peipei, de gewone langstaartaap, en de metjeptjep, de siamang.

Naast den gewonen eekhoorn vindt men in de bosschen den vliegenden eekhoorn.

De krokodil makt ook de Mentaweische wateren onveilig. De Mentaweiers noemen hem si kaoinan, d.w.z. »degeen die in het water is». Dit niet rechtstreeks geven van een naam 
houdt vermoedelijk verband met een soort totemistische vereering ${ }^{1}$ of vrees. De krokodil, de haai en de slang zijn de eenige voor den mensch gevaarlijke dieren.

Slangen vindt men op de Pageh-eilanden in groote hoeveelheden en in verschillende variëteiten. De python komt er veelvuldig voor; de cobra, voor zoover mij bekend is, niet.

De bosschen herbergen een menigte herten, die, met de apen, den geliefkoosden wildbuit van den Mentaweier vormen. Zijn meest gewilde vischbuit is de zeeschildpad.

Elke eenigszins gegoede Mentaweier houdt er varkens op na. Vroeger vonden die dieren een onderkomen in de kampong, bij voorkeur onder de huizen. Om hygiënische redenen is zulks thans door het bestuur verboden, en worden ze ondergebracht in stallen of hokken buiten de kampong.

De muskiet en de agas teisteren de eilanden op geweldige wijze. Bij een muskietenplaag als daar heerscht, is het geen wonder dat de malaria een veel verbreide ziekte is. Opmerkelijk is het, en tevens teekenend voor de muskietenplaag, dat er haast geen Mentaweier is, die niet in het bezit is van een klamboe. Moet een Mentaweier den nacht buitenshuis doorbrengen, dan kan men er zeker van zijn, dat hij een klamboe meevoert bij zijn weinige bagage.

Bij de beschrijving van kampongs, van jacht, visscherij en voedingsmiddelen zullen we met enkele diersoorten nader kennis maken.

Flora en pomona. We hebben reeds gezien, dat het binnenland een oerwoud-vegetatie heeft. Men treft er zware boomen aan in wellicht honderden variëteiten, geschikt zoowel tot het winnen van timmerhout als van getah en damar. Ook rottan is een veel voorkomend boschproduct. Aan sommige kuststrooken en op enkele kleinere eilanden komen ook goede houtsoorten voor, o.a. kajoe bako en kajoe ngara (Mentaweisch: inggra). Laatstgenoemde soort is soms bijzonder mooi gevlamd. Van de kleefsapboomen verdient bijzondere vermelding de ingas-boom. Ingas is een vergiftig boomsap, de werking is

1 Het woord „vereering" is hier wellicht minder op zijn plaats. Van eenig totemisme is mij althans op de Pageh-eilanden niets gebleken. Wel speelt de krokokil een rol in een Mentaweisch verhaal, dat de beschouwen is als een stamsage. 
echter van alle soorten niet even fel. De zwaarst vergiftige ingas dringt door de kleeren heen; de enkele aanraking met een boom of een tak is voldoende, om het geheele lichaam te doen opzwellen en hevige koorts te veroorzaken. Bij het vergiftig maken van pijlen wendt de Mentaweier o.a. ook ingas aan.

Casuarinen en rizophoren vindt men veelvuldig langs verschillende stranden. In het binnenland komen nòch op laagland, nòch op heuvels naaldboomen voor.

Er worden 3 bamboesoorten gevonden: $1^{\circ}$ mètoe, de zware, sterke soort (bamboe bětoeng); $2^{\mathrm{e}}$ omboek, de ordinaire soort, die gebruikt wordt om er het eten in te bereiden, en $3^{e}$ mangeak, een bamboesoort met dunnen stengel en met zeer geringe holte.

Van de voornaamste houtsoorten laat ik hier enkele volgen onder de Mentaweische benaming. Loetjoe (alocasia macrorrhiza?), zeer zwaar en bijzonder hard; (deze soort werd met succes gebruikt voor heiblokken); boeloe sakla, roeman-taoesoe, latjo, tarat, baiko, toilat, ribboe, matjemin, diboeh, boklo, mantarep. Deze soorten zijn nagenoeg alle zwaarder dan water. Voor het vervaardigen van stevige planken en van prauwen gebruikt de Mentaweier gaarne het genoemde matjèmin (dammara alba), dat, hoewel zwaar, zich niet zoo lastig laat bewerken als de andere soorten.

Het land bezit geen groote verscheidenheid van bloemen. In en nabij de kampongs vindt men de békèoe (mal. kěmbang sěpatoe; Lat. hibiscus rosa sinensis), die naast bladeren van crotons veel als opsmuk gebezigd worden. Ook dient hiertoe wel de gandasoeli-bloem, die in het wild veel voorkomt. In de bosschen, en vooral op de kleinere eilanden, treft men vele orchideeën (Ment. kamra) aan, in groote verscheidenheid. De meest voorkomende soorten zijn de phalaenopsis amabilis, de phalaenopsis tetraspis, de vanda sumatrana en enkele dendrobium- en cypripediumsoorten.

Als hoofdvoedsel gebruikt de Mentaweier den knol van de kladi (colocasia antiquorum). Daarnaast oebi (dioscorea) en ketella. De kladi-ladangs zijn meestentijds bijzonder uitgestrekt; het zijn moerassen of moerassige gronden, waar deze knolvrucht weinig verzorging behoeft: ze plant zich welig vanzelf voort. Naast kladi gebruikt de Mentaweier veel sago, den sagopalm vindt men veelvuldig in waterachtig terrein en aan rivierkanten, 
waar ook de nipahpalm overvloedig gevonden wordt. Evenzoo de rotanpalm: van rotan worden hier de beste soorten aangetroffen (o.a. rotan sagoe), die bij vreemde handelaren zeer gewild zijn. Verscheidene prauwladingen rotan vinden geregeld haren weg naar Sumatra.

De klapperboom groeit - behalve in onbewoonde oorden in het binnenland - overal, zelfs op onbewoonde stranden en eilanden. Pisangboomen worden in het wild meer aangetroffen dan in gecultiveerden toestand. Suikerriet en maïs worden slechts hier en daar verbouwd. De meest voorkomende vruchtsoorten zijn: djeroek asem (citrus medica), djeroek nipis (citrus limonellus), doerian (durio zibethinus), manggistan (garcinia mangostana) djamboe (jambosa) tjempědak (artocarpus polyphema) papaja (carica) en ananas (annanassa sativa).

Sporadisch vindt men soms een tabaksplant, zuinigjes gekweekt in de nabijheid van een woonhuis. Hier en daar treft men lombok (capsicum annuum) aan, eene specerij, die de Mentaweier zelden gebruikt.

HOOFDSTUK II.

Administratieve indeeling; bestuur.

Administratieve indeeling. De Mentawei-eilanden vormen administratief een onderafdeeling van de afdeeling Padang (gouvernement Sumatra's Westkust). De afdeelingschef, met den titel van assistent-resident voor de politie, zetelt te Padang, terwijl de eilanden rechtstreeks bestuurd worden door een civiel gezaghebber, met standplaats Siberoet, op het grootste eiland van denzelfden naam. De civiel gezaghebber, een officier, is tevens commandant der op de eilanden gelegerde troepen, die bestaan uit detachementen ter hoofdplaats Siberoet en te $\mathrm{Si}$ Oban (op het eiland Sipora) en te Sawang Toengkoe (op NoordPageh). Bij elk detachement zijn ingedeeld een klein aantal politie-soldaten van Maleischen en Batakschen volksaard, die behalve als politie, ook als tolk dienst doen. Aan geregelde troepen bestaat de totale bezetting uit 9 brigades marechaussée (180 man). 
Gegeven de geografische ligging van de Mentawei-eilanden, kan het niet anders, of deze eilanden moeten reeds bij oude zeevaarders bekend zijn geweest. Oost-Indië-vaarders, die naar Sumatra's Westkust en naar Atjèh voeren, moeten deze eilandengroep wel opgemerkt hebben. Ook moeten Hindoes, Arabieren en Mongolen op hunne tochten naar het Oosten niet onkundig gebleven zijn van het bestaan dezer eilanden. Doch bij het weinig herbergzaam aspect, dat zij boden (de kampongs liggen te diep landwaarts in, dan dat ze van zee uit kunnen waargenomen worden), was het geen wonder, dat men er weinig of geen aandacht aan schonk.

In 1828 werden de Pageh-eilanden voor $\mathrm{f} 400$ per jaar verpacht door het Nederlandsch bestuur, dat daarmede een "gepatenteerd emporium van smokkelgoederen» in het leven riep; drie jaar later werd de pacht afgeschaft, en vele jaren lang bepaalde men er zich toe, de eilanden nu en dan door een oorlogschip te doen bezoeken. In 1864 achtte de Indische regeering het noodig, uitdrukkelijk te verklaren dat de Mentaweieilanden tot ons gebied behoorden; maar eerst in 1887 nam de daadwerkelijke bemoeiïng een aanvang. En in 1904 werden de eilanden van eene militaire bezetting voorzien, wellicht onder den drang der omstandigheden, want tijdens den RussischJapanschen oorlog zochten de belligerante partijen begeerig naar een maritiem station in de Indische wateren. En de Mentawei-eilanden waren daartoe een deugdelijk object.

Bestuur. Het rechtstreeksch bestuur werd van 1893 tot 1897, toen hij door de bevolking werd verjaagd, namens het Gouvernement gevoerd door een Maleischen posthouder, met standplaats Si Oban op het eiland Sipora. Deze ambtenaar had een zeilprauw te zijner beschikking, met welk vaartuig hij de verbinding met de andere eilanden en met Padang moest onderhoüden.

Toen in 1904 de eerste Europeesche bestuursvestiging kwam, werd de toestand geheel anders. Er kwam toen een afdeeling troepen onder bevel van een officier, die tevens met het civiele gezag bekleed was. Het allereerste pionierwerk bestond uit het zoeken van aanraking met de bevolking en het doen van verkenningen, waarbij alle eilanden hun beurt kregen. Een enkele maal keerde de Mentaweier zijn pijl en boog tegen ons, Dl. 70 
doch over 't algemeen - was de aanraking van vredelievenden aard. Geregeld voer nu een gouvernementsstoomer tusschen Padang en de Mentawei-eilanden, om de troepen te voorzien van leeftocht, om ze af te lossen, materialen aan te brengen, enz. Geleidelijk kwam men tot den huidigen bestuurs-toestand, en ook werden de eilanden tweemaal 's maands aangedaan door de booten van de Paket-maatschappij, d. w. z. door de booten, die tusschen Padang en Atjèh varen.

Kwam door dit alles de bestuursvestiging al op vaster gronden te staan, toch werd het Mentaweische volk weinig opgeheven van den lagen trap van beschaving, waarop het stond. Wel was de scheepsverbinding met Sumatra frequenter geworden, doch de Mentaweier maakte daarvan geen gebruik. Ten eerste onderhield de gouvernementsstoomer geen publieke vaart; dit schip was alleen voor bestuursdoeleinden. En ten tweede was de passage per Paketvaart voor den Mentaweier te kostbaar, aangenomen al, dat hij den moed bezat, eigener beweging de reis met zoo'n stoommonster te maken. Van een drukker verkeer met de buitenwereld kwam voor den Mentaweier dus zoo goed als niets.

De civiele gezaghebber beschikt op zijn standplaats over eenig bureau-personeel, w. o. een djaksa ter assistentie in de rechtspraak. Verder staan hem de detachementscommandanten in civiele aangelegenheden ter zijde.

Aan den civielen gezaghebber zijn de kamponghoofden (kepala kampong) verantwoordelijk voor de behoorlijke opvolging van bestuursbevelen, daarin bijgestaan door de opzichters over den heerendienst (kepala rodi). Grootere kampongs zijn onderverdeeld in oemah's, waarvan de hoofden den kepala kampong en den kepala rodi weer behulpzaam zijn in de uitvoering van de hun opgedragen taak. De in oemah's verdeelde kampongs hebben meestal twee kepala rodi.

Veel heeft het gezag dezer Mentaweische hoofden niet te beduiden. Van huis uit voelt de Mentaweier het meest voor absolute regeeringloosheid. Het is veelal met tegenzin, dat de hoofden hun betrekking als zoodanig waarnemen; en het is geen zeldzaamheid, dat die lieden het verzoek komen doen, om hun gezag te mogen neerleggen. Voor hen is het meermalen een zware taak, om èn met het Gouvernement èn met het kampongvolk in goede verstandhouding te leven. 
Vóór onze bestuursvestiging bestond er geen regeeringsvorm, ook niet in den primitiefsten vorm. Noch oemah, noch kampong kenden een gezaghebbend hoofd. Ook kenden de kampongs geen vereeniging tot federatie of negorij. Wel hebben oemah's en kampongs een geestelijk hoofd (rimata), die voorgaat in ritueele diensten, en ook te zorgen heeft voor het naleven der zeden, doch eigenlijk gezag oefent deze persoon niet uit. In tijden van tegenspoed of ziekte ziet men zeer tot den rimata op; hij is, met den sikerre (priester) de man, die door het bezweren van geesten als anderszins veel in het reine heet te kunnen brengen. In het gewone leven gaat veelal invloed ten kwade uit van den rimata; hij is dikwijls stokebrand, die persoonlijke veeten doet ontstaan, waaraan bijna altijd hebzucht ten grondslag ligt.

De anarchistisch aangelegde Mentaweier heeft zoo goed als geen ontzag voor zijne hoofden. Ze zijn voor hem slechts zijns gelijken, die telkens bestuursbevelen komen overbrengen, en die bevelen beteekenen voor hem bijna zonder uitzondering "galai" (werken), hetgeen iets is, dat hem grooten tegenzin inboezemt.

De bevolking van de Pageh-eilanden is geheel geregistreerd. Hoewel een enkele maal daarbij verzet gegleegd werd, heeft de registratie over het algemeen toch een kalm verloop gehad.

Op de Pageh-eilanden heeft men de volgende kampongs:

$$
\text { Noord-Pageh: }
$$

1. Sawang Toengkoe (standplaats detachement).

2. Berre (Maleisch).

3. Baibai.

4. Nemnemleleoe (zendingspost).

5. Kaoete.

6. Salaoinan.

7. Taikako.

8. Boelakmonga,

9. Sabeoegoegoeg.

10. Betoemonga.

11. Silaboe:

12. Karimau.

13. Pasapoeat (Maleisch).

14. Simangaoengaoe. 
132 DE GROEP N. EN Z.-PAGEH VAN DE MENTAWEI-EILANDEN.

15. Simangandjo,

16. Saoemanganja.

17. Matobe.

18. Poeroukat.

$$
\text { Zuid-Pageh : }
$$

1. Bakatmonga.

2. Moentai I.

3. Makalo.

4. Mapopo.

5. Talapoelei.

6. Bosoea-bacha.

7. Labadjaoe.

8. Boeboeket.

9. Boeriai.

10. Saoemang.

11. Boelasat.

12. Tapak.

13. Kabake.

14. Moentai II.

15. Malakopa.

16. Belekraksok.

17. Boekoekmonga.

18. Bosoea-loemoen.

12. Seai.

Zooals reeds vermeld is, zijn grootere kampongs onderverdeeld in oemah's. Ook scheiden zich wel oemah's af, wanneer er oneenigheid bestaat tusschen de kampongbewoners. De afgescheidenen bouwen een nieuwe oemah (vereenigingshuis), en noemen zich naar de plaats, waar zij wonen, of naar de gesteldheid van het vereenigingshuis, doch blijven behooren tot de oorspronkelijke kampong. Men krijgt dan de volgende benamingen :

Taikamonga $=$ die aan de monding.

Taikatiri $=$ " , den bovenloop.

Taikatenga $=$ " " middenloop.

Taibeo-oemah $=$ » van het groote huis.

Taibeo-arigi $=$ » " huis op hooge palen. 
HOOFDSTUK III.

Bevolking; heerendiensten; passenstelsel; belasting; geschiedenis; taal; literatuir; kleeding; tatouage; wapens; wijze van oorlogvoeren; werktuigen en gereedschappen; huizenbouw; huisdieren.

Bevolking. De kleine eilanden van de Pageh-groep zijn onbewoond, eveneens in den regel de kusten. De Mentaweier vermijdt die oorden te bewonen, met het oog op gevaar voor vijanden; de kleine eilanden zijn bovendien onbewoonbaar wegens gebrek aan drinkwater. Zijne kampongs bouwt hij aan een rivier, soms weinig, soms ver stroomopwaarts.

Aan inheemsche bevolking tellen Noord- en Zuid-Pageh te zamen \pm 5500 zielen, waarvan \pm 1200 strijdbare mannen; een zeer laag bevolkingscijfer alzoo. Evenzoo is het geboortecijfer laag; het zielen-aantal is dalende.

Over den óorsprong van de Mentaweische bevolking bestaan verschillende gissingen. Vooraf echter een enkel woord over de vlottende en geïmmigreerde bevolking, en over hare vermenging met de inheemsche.

De vlottende bevolking bestaat in hoofdzaak uit Chineezen, Maleiers en enkele Niassers. Hierbij nog te rekenen de Batakkers, in dienst van het Gouvernement (politiesoldaten) en van de zending (onderwijzers en werklieden). Behalve laatstgenoemden vertoeven zij er uitsluitend voor handelsdoeleinden; hun handel is voornamelijk ruilhandel met de inboorlingen. Hier en daar aan de kust hebben zij een paar primitieve gebouwtjes, dienende tot woonplaats, magazijn van ruilwaren en stapelplaats van ingekochte producten. Bovendien meestal een loods, waar zij copra bereiden. Tot hun beschikking hebben zij zeilprauwen, waarmede ze tusschen de Pageh-eilanden en Sumatra varen. Er is hier voor hen een ruim veld voor afzetterij, die echter flink beperkt wordt door de bepaling, dat zij zich niet mogen ophouden in Mentaweische kampongs Zoodoende is het althans eigen vrije wil, wanneer de Mentaweiers met hen in handelsrelatie treden.

Er zijn ook gevestigde Maleiers, die in twee eigen kampongs wonen, n.l. Berre en Pasapoeat, (beide op Noord-Pageh). 
Laatstgenoemde kampong moet reeds eẻn vrij oude Maleische nederzetting zijn. In een volksverhaal wordt van kampong Pasapoeat reeds in de $18^{\mathrm{e}}$ eeuw gewag gemaakt. De Maleiers van deze kampong hebben zich vermengd met de Mentaweische bevolking, echter zonder hun afkomst prijs te geven Sporadisch zijn er enkele Maleiers, en ook Niassers, die geheel "vermentaweischt» zijn. Dezen hebben geheel en al de zeden en gewoonten des lands aangenomen en wonen ook in de Mentaweische kampongs. Ook trof ik een Atjeher aan, die omstreeks 1870, van Atjèh naar Padang varende, op NoordPageh schipbreuk leed, en als eenige overlevende van de bemanning van het schip, op dat eiland is blijven wonen, en Mentaweier geworden is. Hij sprak nog goed Atjèhsch, schoon niet met het zuivere eigen accent.

Met zekerheid kan dus worden vastgesteld, dat bloedmenging van de inheemsche bevolking heeft plaats gehad met Maleiers en Niassers, enkele Atjehers, en vermoedelijk met Boegineezen. Volgens Neumann moet de baai van Laboean Badjau (Noordoost-punt van het eiland Siberoet) vroeger een schuilplaats geweest zijn voor Atjehsche en Boegineesche rooversprauwen. Het is niet onmogelijk, dat die beide volken zich ook met de Mentaweiers hebben vermengd.

Het is uiterst moeilijk, zoo niet onmogelijk, gegevens te verkrijgen omtrent den oorsprong der Mentaweische bevolking. De menschen kunnen lezen noch schrijven (behalve de kinderen, die thans het onderwijs op de zendingsscholen volgen), en zoodoende bestaat er geen enkel schriftuur, dat ons naar vroegere tijden verwijst. Slechts hier en daar is uit een volksverhaal te vernemen, dat er betrekkingen hebben bestaan met den vasten wal van Sumatra en met de overige Mentawei-eilanden. ' De geschiedenis van het volk is niet veel verder bewaard gebleven dan tot het thans levende geslacht. In de oemah sabeoe (vereenigings- tevens bedehuis) van de kampong Silaboe (NoordPageh) werd tot vóór eenige jaren een klein kanon bewaard, welke omstandigheid mij een aanwijzing was voor vroeger bestaan hebbende betrekkingen met de buitenwereld. Na veel geduld geoefend te hebben, kreeg ik een paar ouden van dagen aan het spreken, en kon ik de volgende geschiedenis opteekenen:

1 Volgens Morris wordt de Maleier sa-s'a-reoe genoemd. Vrij vertaald, beteekent dit: „menschen van vroeger tijd." 
In de $18^{\mathrm{e}}$ eeuw voeren de Boegineezen op Padang, waar zij hunne weefsels verkochten. Een Boegineesche prauw ging van Padang naar de Mentawei-eilanden, waar de bemanning tripang wilde visschen. Ze kwam vóór de kampong Silaboe, waar ze het anker liet vallen dicht bij het eiland Silaboemabeoe (Poelau Montrado). Het schip bleef er weken lang liggen, en er ontstonden vriendschappelijke betrekkingen tusschen Mentaweiers en Boegineezen, welke laatsten herhaaldelijk in de kampong kwamen om zich o.a. te voorzien van vruchten.

Op zekeren dag gingen er 4 vrouwen van Silaboe per sampan naar de eilanden, toen plotseling de Boegineezen, 6 in getal, kwamen opdagen, de vrouwen met zich medesleurden, en haar geweld aandeden. Toen de vrouwen in de kampong teruggekeerd waren, vertelden ze aan hare mannen de schanddaad der Boegineezen.

Toen dit onder het kampongvolk bekend was geworden, belegden de mannen een vergadering, en besloten zij de Boegineeżen te dooden en zich meester te maken van de goederen uit de prauw. Aldus geschiedde; toen de Boegineezen van de tripangvangst terugkeerden naar hun vaartuig, werden ze onverwachts door de Mentaweiers gevangen genomen en gedood. Het gelukte echter aan één der Boegineezen te ontkomen en zich te verschuilen in het bosch op Montrado, zonder dat de Mentaweiers hem konden ontdekken.

De Boegineesche prauw dreef af naar zee en strandde bij Malakopa op Zuid-Pageh, alwaar de overblijfselen ervan heden ten dage nog te zien zijn op het strand.

De ontkomen Boeginees zwom, toen het donker geworden was, van Montrado over naar den vasten wal van NoordPageh; daar zwierf hij 4 dagen zonder eten rond in het bosch en over heuvelen, tot het hem eindelijk gelukte, Pasapoeat te bereiken, vanwaar hij met een prauw, bemand met Maleiers, naar Padang terugkeerde.

Bij de uit de prauw buitgemaakte goederen bevonden zich o.a. een kanon, een geweer en een kris met drie edelsteenen.

Hoeveel moeite ik mij ook gegeven heb, het geweer en de kris heb ik niet kunnen ontdekken. Ook het kanon was ver- 
dwenen uit de oemah sabeoe, het was aan den rivieroever weggeworpen. Toch gelukte het $\mathrm{mij}$, dit voorwerp te doen terugvinden, doch het kon door opschrift noch anderszins eenige aanduiding van herkomst geven.

Veel schuwheid en vrees moest bij deze onderzoeking overwonnen worden; de Mentaweiers waren bang voor straf wegens het in het bezit hebben van een kanon, dan wel wegens den moord door hunne voorvaderen bedreven!

Een ander verhaal dat aanwijzing geeft omtrent vroeger bestaan hebbende betrekkingen met Sumatra, en tevens volgens de Mentaweiers de scheiding der eilanden Noord- en Zuid-Pageh verklaart, moge hier een plaats vinden. ${ }^{1}$

Op het eiland Bakat Binoeang ${ }^{2}$ stond in vroeger tijden een reusachtige boom, die zóó hoog was, dat hij zijn schaduw wierp tot in Moko-Moko, op den vasten wal van Sumatra. Die schaduw was voor de daar wonenden zeer hinderlijk, daar zij o.a. hun padi niet behoorlijk konden dragen. De menschen van Moko-Moko trokken daarom naar het eiland Bakat Binoeang om den hinderlijken boom te vellen. Ze kapten ijverig; reeds aan het eind van den eersten dag hadden ze links en rechts 3 depa (vaam) diep gekapt. Doch deze geweldige boom had zoo'n groeikracht, dat de menschen den volgenden morgen bij het ontwaken het gekapte weer dichtgegroeid vonden Ze besloten daarom dag en nacht door te kappen. Lang, zeer lang werd op deze wijze doorgewerkt, legio bijlen werden bij dit werk van de stelen afgeslagen. ${ }^{3}$ Dan werden de bijlen weer

1 Volgens Veth zou de Fransche commandeur de Beaulieu in 1621 van de bewoners van Tiko (Sumatra's Westkust) vernomen hebben, dat er in het Westen 2 onbewoonde eilanden waren; het eene noemden de Hollanders Nassau, het andere Pora, terwijl een daar ten Noorden van gelegen eiland, Mentabeij genaamd, wel bewoond was. De bewoners die met Tikoe handelden spraken een vreemde taal. Hier is sprake van één eiland Nassau, hetgeen (als het verhaal waarheid bevat) erop zou duiden, dat Noord- en Zuid-Pageh toen nog één eiland vormden of als één eiland werd beschouwd, en dat vóór de $17^{\circ}$ eeuw alleen Siberoet bewoond was. Na dien tijd zou dan de bevolking van Siberoet geëmigreerd moeten zijn naar Sipora en de Pageheilanden.

2 Aan den Oostelijken ingang van Straat Sikakap.

${ }^{3}$ Hier wordt bedoeld de bij de Mentaweiers thans nog allerwege in gebruik zijnde "belioek" een soort dissel, die met rottan stevig aan een houten steel wordt vastgesnoerd. 
voorzien van nieuwe stelen, terwijl de oude stelen, benevens het oude bindrottan in zee weggeworpen werden, de stelen op één hoop, en het rottan op één hoop. Zóó vervaarlijk groot was het aantal stukgeslagen bijlen, dat de weggeworpen stelen een eilandje deden ontstaan, n.l. Poelau Sangka (dicht bij moeara Seai, op Zuid-Pageh), terwijl het eilandje Kerawé (vóór moeara Baiboi op NoordPageh) zijn ontstaan te danken heeft aan het weggeworpen bindrottan.

$\mathrm{Na}$ langen tijd van ingespannen arbeid viel de boom in Westelijke richting. De zware stam sloeg het eiland Pageh in twee deelen, en deed de Straat Sikakap ontstaan. De groote en kleine takken van den gevallen boom sloegen groote gaten en gleuven diep landwaarts in, en zoo ontstonden verschillende baaien benevens rivieren met hare mondingen.

Er wordt in dit verhaal ook wel melding gemaakt van een vogel, die zijn nest in den boom had gebouwd. Het voortgezette verhaal luidt dan aldus:

In dien grooten boom zat een reusachtige vogel ${ }^{1}$, een manjang ${ }^{2}$, die, als hij zich hoog in de lucht verhief, het geheele land Mentawei beschaduwde. Het was een zeer gevreesde vogel, die menschen verslond. Toen de boom omviel, vloog de vogel weg, en werd nooit meer teruggezien.

Zooals gezegd is, bestaan omtrent de eigenlijke afstamming van de Mentaweiers slechts hypothesen. Veel overeenkomst vertoonen ze op het eerste gezicht met Papoea's; ze loopen nagenoeg naakt, versieren zich gaarne met kralen, schelpen, veeren, bloemen, bonte lapjes enz.; schieten met pijl en boog, en vijlen hunne tanden in driehoekigen vorm. Het naaktloopen, het tatoueeren en het schieten met pijl en boog zijn eigenschappen, die de Mentaweiers met het Melanesische ras gemeen hebben.

Hun uiterlijk vertoont ook veel overeenkomst met de Sakei's (Malakka). Ook volksaard, zeden en gewoonten komen merkwaardig overeen. Beide volken leven in hoofdzaak van knolvruchten, daar de rijstbouw hun onbekend is, evenals de tabaksbouw

\footnotetext{
1 Volgens sommigen 3 vogels, 1 wijfje en 2 mannetjes, waarvan vooral het wijfje een voor den mensch gevaarlijk dier was.

${ }^{2}$ Groote roofvogel, een soort arend.
} 
bouw. In rijst en tabak drijven ze een levendigen ruilhandel. De aap is voor den Sakei zoowel als voor den Mentaweier een lekkernij; beiden jagen er op met vergiftige pijlen, door den eerste geschoten uit een blaasroer, door den laatste met een boog. Beiden dragen als nagenoeg eenigst kleedingstuk: de mannen een schaamgordel uit boombast, de vrouwen rokjes van bladeren. De kralen halskettingen der Mentaweiers, het versieren hunner haren met bonte lapjes, bloemen en bladeren, het beschilderen van gezicht en lichaam, dit alles vindt men bij de Sakei's terug. Reide volken gebruiken graag tabak; de Mentaweier rookt ze, de Sakei kauwt ze. Alleen het sirihkauwen van den Sakei kent de Mentaweier niet.

Neumann' rangschikt de Mentaweiers anthropologisch tot den Maleisch-Poynesischen stam. Daar enkele overleveringen erop duiden, dat de Mentaweiers van Sumatra afkomstig zijn, en dit eiland vroeger door Polynesiërs bevolkt is geweest (later door de Maleiers verdreven), oppert Neumann de mogelijkheid, dat de Mentaweiers een voortgezet ras zijn van enkele achtergebleven Polynesiërs.

Ook Von Rosenberg constateert bij de Mentaweiers zuiver Polynesische kenteekenen; hij vond groote overeenkomst met de bewoners van Hawai, Marquesas, Fidji, enz., en rekent ze dus tot den Oceaanschen stam (horao neptunianus).

Bickmore, Mess en Morris vinden in de Mentaweiers groote verwantschap met de Maleiers, laatstgenoemde - naar de taal oordeelende - tevens met de Dajaks.

Dr. Oudemans verklaart ze verwant aan Bataks, Niassers en Batoeërs.

Maass ziet in hen een verspreid overblijfsel van de oerbevolking van Sumatra, die tot de groote Maleisch-Polynesische volksgroep behoort.

Funghuhn acht hen verwant aan de Bataks.

Volz $^{2}$ vindt vele overeenstemmingen tusschen Bataks en Mentaweiers, o. a. in huizenbouw, ornamentiek en taal. Ook de eilandennamen Siberoet en Kobo (zooals Sipora ook wel heet) zijn voor hem aanwijzingen tot verwantschap met Bataks. Wat Siberoet betreft, schrijft hij:

${ }^{1}$ Zie Tijdschrift van het Kon. Ned. Aardrijkskundig Genootschap $2^{\circ}$ serie, dl. XXVI, 1909.

2 Nord-Sumatra. I. Die Batakländer. Berlin, 1909. Blz. 304. 
"Im nördlichen Karo-Land und nur dort (?) kehrt auf«fallend häufig der Name Barus wieder: in den Dörfern "Barus djahe (Sitz eines der vier Haupt-Sibajaks), Barus djulu, Tandjong Barus; Deleng Barus ist der Name eines «der höchsten Berge hier, und Lau Barus heiszt der grosze "Flusz des Si Nabun. Bekannt ist ferner der alte Hafenplatz «Baros an der Westküste. Derselbe Name findet sich bei " einem der Hauptstämme der Simsim als Sibarutu wieder, "der seltener auch in Kẹpas vorkommt. Dieser Name aber "ist dem Batak etwas Besonderes. "Der Name Baros» schreibt "Warneck, "hat für die Batak einen geheimnisvollen Klang.» "Die gröszte Insel der Mentawei-Gruppe hat den gleichen "Namen: Siberut. Hier steckt ein alter Zusammenhang, der "uns durch die Barussae des Ptolemäus näher gerückt wird, "und der Gedanke liegt nahe, in dieser Unterschicht die "Barussae zu suchen, die Verbreitung deck sich auffallend.»

Ik geloof, dat de naam "Siberut» slechts een zeer toevallige klankgemeenschap heeft met "Baros» en "Barus.» Si biroet is de Mentaweische naam voor muis. Nu heeft het eiland wel eenigszins den vorm van een muis, doch ik geloof niet, dat de vroegere naamgevers een voldoenden overzichtelijken blik op de kustlijn gehad hebben, om die overeenkomst te ontdekken, Wellicht dat de muis, die inderdaad op vele plaatsen een plaag is voor het eiland, den stoot heeft gegeven tot die naamgeving.

Volz zegt verder, dat de Koeboerassen op Sumatra eens een voorname rol hebben gespeeld, getuige de naam Kobo (Sipora). Volgens een bekende legende hebben de Menangkabauers hun naam te danken aan "de overwinning der karbauwen.» De afleiding kabou $=$ karbouw is volgens Volz onmogelijk, het is slechts volks-ethymologie. Daarentegen komen kabau en kobo volgens de spraak volkomen overeen, zondat men ten rechte moet spreken van «de overwinning over den Kobo.» Want, zegt hij, Menangkabau, Kobo en Koeboe zullen toch wel niet toevallig een woordgelijkheid zijn?

Dat de afleiding kabau $=$ karbouw onmogelijk zou zijn, kan ik niet onderschrijven. Dit geeft aan het betoog van Volz iets gezochts, en moet m. i. aanleiding geven tot weifelen aangaande het aannemen der hypothese, dat de naam Kobo (Sipora) iets met Koeboes uitstaande zou hebben. 
Volz' stelling: "Auf den Mentawei-Inseln müssen wir, «abgesehen von den Urmalaien, noch eine vormalaüsche Bevöl"kerung als Mischungselement vermuten, die mit Kubus, Senoi, "Enganesen u. s. w. nahe verwandt ist, heeft veel waarschijnlijks, wanneer men aanneemt, dat een gedeelte van de verdreven voor-maleische bevolking achterbleef, en dat daaruit de Mentaweiers zijn ontstaan.

Dit nu lijkt mij de meest aannemelijke onderstelling omtrent de afstamming der Mentaweiers ${ }^{1}$ Van de door de Maleiers verdreven Polynesiërs moet een gedeelte zich - hoewel geisoleerd - hebben weten staande te houden. Een fractie daarvan heeft de Westerstranden van Midden-Sumatra en het (vroeger bestaan hebbende) paralelgebergte van de Boekit Barisan bewoond, en bleef op zichzelf staan, toen de eilandenreeks (Simaloer tot Engano) zich van het eiland Sumatra scheidde. Later hebben zich verschillende volksstammen met die Polynesische fractie gemengd, vermoedelijk zelfs Mongolen en Japanners. De veel voorkomende schuine stand der oogen pleit voor Mongoolsche inmenging; de korte, gespierde bouw der mannen, de gedrongen bouw en de waggelgang der vrouwen duiden op Japansch bloed. Het haar is dikwijls sluik als bij de Japanners, terwijl de zwarte pigmenteering niet overal streng doorgevoerd is; bij enkele Mentaweiers is een bruin-roode haarnuanceering te onderkennen, die zou kunnen duiden op Kaukasische menging.

De bevolking van de Pageh-eilanden woont in kampongs, als regel ver van de kust gelegen, terwijl de kampongs meestal dagen loopens of roeiens van elkaar verwijderd liggen. De grootste kampong, Tai-Kako (Noord-Pageh), telt \pm 160 volwassen mannen, de kleinste, Moentai I (Zuid-Pageh), slechts een 5-tal. De bevolking maakt bijna nooit gebruik van verkeerswegen te land, nagenoeg alle verkeer heeft over water plaats. Zoodoende is de Mentaweier een ervaren zeeman geworden, een onvermoeid roeier. Te land bestonden vroeger slechts enkele paden, hoofdzakelijk loopende van de kampongs naar de ladangs, terwijl een heel enkel pad verbinding gaf tusschen Oost- en Westkust van de eilanden. Het Europeesch bestuur heeft alle kampongs door paden doen verbinden, en is nu doende die paden in behoorlijke wegen te laten veranderen.

1 Zie ook de conclusies hierachter. 
Heerendiensten. Het aanleggen van wegen geschiedt in heerendienst, waartoe de volwassen mannen éénmaal per week worden opgeroepen. Wegen-aanleg, het slaan van bruggen, enz. waren voor den Mentaweier onbegrijpelijke zaken; voegt men daarbij zijn aangeboren luiheid en de vele gelegenheden, die hij aangrijpt, om poenèn te houden (ritueel gebruik, waarbij hem zoo goed als alle arbeid verboden is), dan is te begrijpen, dat bij de heerendiensten degelijke voorlichting en scherp toezicht onzerzijds geboden waren. Om de contrôle te vergemakkelijken, werden alle kampongs verdeeld in 6 groepen, die elk een verschillenden werkdag in de week kregen. Zoodoende konden de militaire patrouilles desgewenscht dagelijks op contrôle uitgaan. Naarmate de bevolking gewend werd aan gehoorzaamheid, orde en regelmaat, werd geleidelijk de verantwoordelijkheid voor de uitvoering van heerendiensten opgedragen aan de kamponghoofden; aan sommigen van deze kon ook het traceeren van wegen worden overgelaten. Thans zijn de "kapala rodi» in het bijzonder aangewezen voor het toezicht op de heerendiensten.

Door ons bestuur werd ook geeischt het schoonmaken en schoonhouden van kampongs, huizen en erven. Hier moest dikwijls streng opgetreden worden, want van hnis uit wil de Mentaweier niets van schoonmaken weten; zijn adat brengt zelfs mede, dat hij zijn huis nimmer schoonmaakt. Treedt men een oemah sabeoe binnen, dan bemerkt men, dat alle daar bewaard wordende voorwerpen, zooals hertengeweien, beenderen en schedels van wild, trommen, gongs, enz. dik in de stof en de spinnewebben zitten. Het bestaan van een bezem kende de Mentaweier niet; had hij iets bijeen te vegen, dan was een tak met blaren of een vorkvormig uitloopend stuk bamboe hem daartoe voldoende. Latrines of privaten zijn hem onbekende zaken, een gat in den vloer binnen in het huis of op het achterbordes van zijn woning (die op palen staat), en zijn W.C. is klaar. De onder het huis loopende varkens halen de menschelijke faeces weg, doch deponeeren er de hunne!

Onnoodig te zeggen, dat een van de eerste bestuursmaatregelen was, zindelijkheid in de kampongs te brengen. Dit ging niet in eens, doch eischte overleg en geduld. Deze groote schoonmaak moest hand aan hand gaan met den aanleg van wegen, terwijl den. Mentaweier de noodige tijd gelaten moest worden om zijn ladangs te bebouwen, klappers te plukken, op jacht en op 
vischvangst te gaan, enz. Een doelmatige tijdverdeeling was daarvoor noodig; het luie leventje van vroeger, waarin de Mentaweier meer aan "poenèn" deed dan aan werken, was uit. Wel werd hem billijkerwijs gelegenheid gelaten tot poenèn, doch niet dan nadat hij behoorlijk het hem opgedragen werk had voltooid. Zoo verkeert thans de Mentaweier in een overgangsstadium, waarin hij bezig is, een ordelijk, zindelijk en arbeidzaam mensch te worden.

Passenstelsel. Zooals reeds eerder vermeld is, zijn de bewoners van de Pageh-eilanden allen geregistreerd, d. w. z. elke volwassen mannelijke bewoner is in het bezit van een door het bestuur afgegeven kampongpas, waarin vermeld staan zijn kampong, c. q. zijn "oemah», zijn naam, signalement, vermoedelijke ouderdom en bijzondere kenteekenen. Deze pas moet hij bij het verlaten van zijn kampong steeds bij zich dragen. Voor reizen naar de overige Mentawei-eilanden of naar Sumatra wordt hem een reispas uitgereikt.

Ook de gezeten Maleische bevolking is in het bezit van kampongpassen, terwijl de vlottende bevolking voorzien is van een bewijs van toelating dat afgegeven wordt voor ten hoogste één jaar, en dan weer verlengd kan worden.

Belasting. De inheemsche bevolking betaalt geen belasting. De vlottende bevolking betaalt hare belasting, wacht-, diensten heerendienstgelden ter plaatse, waar zij de reispassen naar de Mentawei-eilanden ontvangt.

Geschiedenis. De vroegere geschiedenis der Mentaweiers ligt vrij wel in het duister. Enkele Europeesche onderzoekingsreizigers, die de Mentawei-eilanden bezochten, vermochten niet, ook maar eenigszins belangrijke gegevens dienaangaande te verzamelen. Onder hen zijn te vermelden de Italiaan Modigliani en het drietal Alfred Maass, Dr. med. Morris en Emanuel Rostados. De eerstgenoemde bezocht in 1894 de bocht van $\mathrm{Si}$ Oban (Sipora); van zijne lieden werden enkelen door de bevolking met pijlschoten gedood, terwijl hijzelf zwaar ziek naar Padang moest terugkeeren. De drie laatstgenoemden bezochten $\mathrm{Si}$ Oban in 1899, en verzamelden belangrijk materiaal inzake ethnografie, taal, enz. Een bezoek aan Siberoet was hun niet 
toegestaan, omdat het Gouvernement hun, wegens de vijandelijke gezindheid der bewoners, geen veiligheid kon waarborgen. Hun voorgenomen reis naar de Pageh-eilanden mislukte door tegenwind; op Sipora maakten de bewoners bezwaar tegen hun komst in de kampongs, zoodat zij hoofdzakelijk aanraking met de bevolking moesten zoeken door de lieden bij zich te laten komen.

Siberoet had toentertijd een niet te vertrouwen bevolking, doch ook thans nog hebben de bewoners der overige Mentaweieilanden ongaarne aanraking met die van Siberoet, omdat zij op hunne tochten daarheen steeds vijandelijkheden ondervonden, en verscheidene van hen daarbij het leven moesten laten. Staan dus de bewoners van Siberoet als oorlogszuchtig te boek, die van de overige eilanden kunnen vredelievend genoemd worden. Slechts de lieden van Siberoet tellen het schild onder hunne bewapening, waaruit blijkt, dat zij er op bedacht zijn, hunne wapenen tegen menschen te keeren. Die van Sipora en de Pageh-eilanden hebben hunne wapenen in hoofdzaak voor de jacht, en kunnen dus het schild missen.

De meeste vijandelijkheden, tusschen Mentaweiers onderling of tegen ons gezag, zijn dan ook ten laste der bevolking van Siberoet te boeken.

Het ligt in den Mentaweischen volksaard, zich af te scheiden, wanneer men niet in vriendschap en eensgezindheid kan samenleven. Dit geeft voedsel aan de meening van Marsden, die verkondigt, dat Siberoet de bakermat is van de Mentaweiers, en dat de bevolking zich van daar over de andere eilanden verspreid heeft. De krijgszuchtige aard der lieden van Siberoet heeft vermoedelijk de milder gestemden bewogen, zich andere woonplaatsen te kiezen, en zoo moeten deze laatsten dan op Sipora en op de Pageh-eilanden zijn terechtgekomen. Tusschen Sipora en de Pageh-eilanden hebben, voor zoover is na te gaan steeds vriendschappelijke betrekkingen bestaan.

Er bestaan verschillende Mentaweische volkverhalen en legenden doch te vergeefs zoekt men daarin naar gegevens omtrent vroegere geschiedenis.

Taal. Het Mentaweisch is een op zichzelf staande taal, volgens Morris verwant aan het Dajaksch. De bewoners van Siberoet, Sipora en de Pageh-eilanden spreken de taal in drie 
verschillende dialecten, die echter onderling slechts weinig verschillen. Het moet met de taal wel hetzelfde gegaan zijn als met de bevolking zelve: af komstig van Sumatra's vasten wal, bijeengebleven op Siberoet, en later verspreid over de andere eilanden. De weinige aanraking der eilandenbewoners onderling is dan later aanleiding geweest tot het ontstaan van drie dialecten, n.l. die van Siberoet, van Sipora en van de Pageheilanden.

Evenals de bevolking, moet ook de taal onderhevig zijn geweest aan vreemde invloeden. Men oordeele de overeenkomst van enkele telwoorden in de onderstaande talen:

\begin{tabular}{r|l|l|l|l|l|l}
\hline \hline & $\begin{array}{c}\text { Menta- } \\
\text { wèisch }\end{array}$ & Bataksch & Atjèhsch & Maleisch & Javaansch & $\begin{array}{c}\text { Soenda- } \\
\text { neesch }\end{array}$ \\
\hline 1 & sarah & sada & sa & satoe & sidji & hidji \\
2 & doewa & doewa & doewa & doewa & lóró & doewa \\
3 & tèloe & toloe & lěhée & tiga & téloe & tiloe \\
4 & épat & opat & peuët & ampat & papat & opat \\
5 & lima & lima & limong & lima & limå & lima \\
6 & ènem & onom & nam & anam & něnĕm & gěnĕp \\
7 & pitoe & pitoe & toedjōh & toedjoeh & pitoe & toedjoeh \\
8 & baloe & waloe & lapan & delapan & woloe & delapan \\
9 & siba & sia & sikoereuēng & sembilan & songå & salapan \\
10 & poeloeh & sampoeloeh & siplōh & sépoloeh & sapoeloeh & sapoeloeh
\end{tabular}

De groote overeenkomst met Bataksch springt dadelijk in het oog.

De namen van aan Mentaweiers oorspronkelijk niet bekende of ingevoerde dieren en voorwerpen staan in het Maleisch, b. v. koe $=$ sapi ; eend $=$ bèbek; bijl (een soort dissel, die men in den steel kan omdraaien, en zoodoende in de lengte en in de breedte kan gebruiken) = b̌lioek, verbasterd van het Maleische bělioeng; rijst $=$ bera, verbasterd van het Maleische běras, enz.

De meeste plaatsen op de Pageh-eilanden ontleenen haar naam aan iets bijzonders, dat daar wordt aangetroffen :

Boekoekmonga .... koraalsteen van de riviermonding. Belèkraksok . . . . . belèk $=$ vallen; raksob $=$ zwaar koperdraad, waarvan armringen gemaakt worden, of wel de armringen zelve. (Aan deze naamgeving is blijkbaar een geschiedenis verbonden.)

Malakopa ..... mangistan.

Moentai . . . . . . djeroek (citrus.) 
Makalo. . . . . . zout van smaak.

Poeroukat. . . . . . badplaats; van merou $=$ baden.

Matobe . . . . . van tobè $=$ kajoe baroe of waroe (hibiscus taliaceus), boom, van welks bast touw gemaakt wordt.

Saoemanganja...... sa-oema(h)-nganja $=$ een jonge oemah (huis).

Silaoinan. . . . . . si-la-oinan $=$ aan de zijde van het water; meer waarschijnlijk: sila-oinan $=$ gespleten water (de kampong ligt n.l. bij een samenvloeiing van twee rivieren).

Silaboe. . . . . . . van laboe $=$ zeestraat.

Ook de personennamen hebben alle een beteekenis, b.v.

Siroearere..... . de tweebeenige.

Sitamerem. . . . . die niet slaapt.

Sitamone ..... die geen veld heeft.

Sitamaila. . . . . . die zich niet schaamt.

Simaroeaisou .... die spoedig weent.

Sisaramata. . . . . . de eenoogige.

Siroeamandri .... . die twee bruiden heeft.

Sikataitoeboe. . . . die met het leelijke lichaam.

Sisaratinoe ..... die slechts kralen heeft.

Sipakelekatai .... die het slechte verbergt.

Sipoedjamandri. . . . die de bruid bedriegt.

Amoiankoinia.... waarom is hij gekomen.

Sitapeimalainge... die nog niet schoon is.

Sipilialei. . . . . . die een gezel kiest.

De Mentaweier is volslagen analphabeet. Een eigen letterschrift heeft hij zeer waarschijnlijk nooit gehad. Een behoorlijke spraakkunst van de taal bestaat niet, ofschoon er wel degelijk grammaticale regels zijn op te merken. O.a. heeft dr. Morris een verdienstelijken arbeid verricht, door een overzicht over het Mentaweisch samen te stellen ${ }^{1}$, doch dit werk, uit Duitsche bron, stelt ons phonetisch teleur. Wel heeft Morris zijn taalstudie en zijne aanteekeningen op de Mentawei-eilanden zelf gemaakt, doch als tusschenpersoon (tolk) een Maleier gebruikt, hetgeen een bruikbare methode is voor iemand, die het Maleisch volkomen machtig is. En dit laatste is aangaande dr. Morris sterk te betwijfelen.

I Die Mentawei-Sprache; Berlin, 1900.

DI. 70 
Slechts weinige Europeanen kennen de Mentaweische taal, en dit mag geen bevreemding wekken, omdat er slechts enkele Europeanen op de eilanden verblijf houden, t. w. de civiel gezaghebber, de officieren-detachementscommandanten, enkele onderofficieren en de zendelingen (de soldaten die de bezetting vormen, zijn van inlandschen landaard). Continuïteit is bij de militairen ver te zoeken, en zoodoende spreken zij in den regel slechts even voldoende van de taal, om een kort gesprek over dagelijksche zaken met den Mentaweier te kunnen voeren. Anders is het met de zendelingen gesteld, die de taal grondig machtig zijn. In den regel komen zij rechtstreeks uit Europa of uit de Bataklanden naar het zendelingenstation op NoordPageh; het Maleisch is hun dan zelfs nog onbekend. Voorwaar een lastige positie, doch de meest practische leerschool (ofschoon een harde) om in korten tijd de inheemsche taal aan te leeren. Een grondige kennis van de taal is voor hen te meer noodig, omdat zij daarin abstracte begrippen moeten uitdrukken, die de Mentaweier niet kent, en die in zijn weinig ontwikkelde brein moeilijk ingang vinden, als: heilige geest, eeuwig leven, hemelsche genade, wederopstanding, voorzienigheid, enz.

Er zijn verscheidene niet-Europeanen, die het Mentaweisch vlot spreken. Onder hen zijn in de eerste plaats te noemen de Maleische en Bataksche politie-soldaten, die veelal jaren lang verblijf houden op de Mentawei-eilanden, en bijna dagelijks omgang hebben met de bevolking. Behalve hunne politiediensten, hebben ze ook diensten te verrichten als tolk. Met hen zijn, wat kennis der Mentaweische taal aangaat, minstens op één lijn te stellen de Bataksche hulponderwijzers, tevens godsdienstonderwijzers, in dienst van de zending. Dezen toch wonen in afgelegen kampongs, en zijn dagelijks in aanraking met de bevolking. Verder spreken de meeste Maleische en Chineesche zeevaarders en handelaars op den Mentawei-archipel vrij goed Mentaweisch.

Er zijn zeer weinig Mentaweiers, die Maleisch spreken of verstaan; slechts een enkele spreekt zuiver Maleisch. Deze weinigen ontleenen hun kennis van de Maleische taal aan veelvuldigen omgang met Maleische en Chineesche handelaren.

Zooals reeds is opgemerkt, bestaan er drie dialecten van het Mentaweisch. Onderling verschillen ze echter weinig, en men kan zich met het eene dialect gemakkelijk verstaanbaar maken bij degenen, die een ander dialect spreken. 
Gaandeweg zal de kennis van Maleisch bij de Mentaweiers meer ingang vinden, omdat die taal tegenwoordig als leervak is ingevoerd op de zendingsscholen.

$\mathrm{Om}$ een indruk te vestigen van woorden en klanken uit de Mentaweische taal, volgen hier eenige liederen in die taal, zoo als ze op de zendingsscholen worden onderwezen.

$$
\text { Vlagg eli ed. }
$$

(gezongen op de wijze van "Wien Nederlandsch Bloed").

Kasé si-itjo manderamai

Si tèloe ngakomakan

Boei ta iagai topitmai

Masirendret tebai ngantoman

Siaket kakai rimata

Sipoeoni Wilhelmina

Sibakat sangamberi noesa ne

Sibakat Sakalangan te

Sibakat Sakalagan.

Iangan te ne manderamai

Sipoeoni Bolanda

Ke itjo ne sagakmai

Boei ta rapoeloto te nia

Magege poi sidjago et

Salandroe sipoebetoeët

Masikau loemoen dili djondra et

Ka sipasiasa nene

Ka sipasiasa ne

Tapoi ka kai sipoenoesa ne

Samberi Sakalagan

Koba kai koeitibai nene

Katet bacha ka rimatakai

Koetindrou kai ka Oekoeita

Sipoelaggai ka manoea

Masikau oektoek ka ina laggai

Siobanake noesamai

Boele mabaoe aratmai.
Wie onze vlag ziet

met drie verschillende doeken die wete, dat wij trouw zijn te gehoorzamen aan de leer die ons geschonken is door Koningin Wilhelmina het Hoofd van al deze eilanden j het hoofd der Mentaweiers.

Dat is onze vlag ze heet Holland als onze vijanden die zien zullen zij dezelve vreezen want sterk zijn hare bewakers de soldaten met geweren om straf te geven voor hun [slechtheid

f aan degenen die haar bespotten.

Maar wij die deze eilanden bewonen, alle Mentaweiers wij willen dit zeggen:

uit liefde voor onze Koningen bidden wij onzen Vader die in den hemel woont. dat $\mathrm{Hij}_{\mathrm{Zijn}}$ zegen moge geven [aan de moeder van het dorp [(de Koningin) die gegeven heeft aan ons eiland vrede en nieuwe zeden. 
Oto ke noe-itjo maroembe

Manderata Bolanda

Boei ta noeroroi ma

Masikau tebai hormata

Ka mata't sibakat sita

Radjanta et Wilhelmina

Sipoe-oekoe sangalio Bolanda

Samba polakta India

Sakalagan leuw bagai
Dus als gij ziet het gedeelde (3 [kleuren)

dat is onze Hollandsche vlag groet ze dan werkelijk

en bewijst haar eer

want ons Hoofd is namelijk

onze Koningin Wilhelmina

die heerscht over geheel Holland en over (onze aarde) Indië en ook over de Mentaweiers.

Koningin's Verjaardag. (gezongen op de wijze van 't "Wilhelmus").

Pateangkat bachata

Gogoi kinenegen

Ai poeioetoekat mata

Radja Bolanda en

Rimata Wilhelmina

Sibakat sita ne

Makate leuw bachania

Ka Sakalagan te

Patetonem bochata

Gogoi kinenegen

Ka sikoepkoep toeboeta

Ka laggai India en

Mangka bachata tebai

Ka senet noesata

Masioe moenake bai

Oni Wilhelmina.

Patekate bachata

Gogoi kinenegen

Manindrau ka Oekoeita

Toenoe Toeboenia en

Boele iake oektoek

Samba paeroekat

Ka radja Wilhelmina

Ina 't Sakalagan.
$\mathrm{O}$, hoe vroolijk is ons hart

Op dezen dag

den geboortedag

van de Koningin van Holland

onze Koningin Wilhelmina

die ons Hoofd is

die ook bemint

de Mentaweiers.

Hoe vol vertrouwen in ons hart op dezen dag

in degene die ons beheerscht

hier in Indië

vroolijk zijn allen

op elk eiland

om te roemen

den naam Wilhelmina.

Vol liefde is ons hart

op dezen dag

zoodat wij onzen Vader bidden voor Haar

dat hij geve zegen

en heil

aan Koningin Wilhelmina

de moeder der Mentaweiers. 
Kerstlied.

(Stille nacht, heilige nacht).

Konan kai itjo bai

Toga nen siperem

Ka kelioe sioeraunendra

Ka bebenia ai si Maria

Ina simatotopit (bis).

Konan kai itjo bai

Pato nen ka mone

Sibabara ka malaika ne

Pate eroe oeraira nene

Aiat Toeanta Jesu (bis).

Konan kai itjo bai

Sidjago bibiri

Amandjoe rangenake

Soibo nene pei le rasese

Sikau tarek bachadra (bis).

Konan kai itjo bai

Bara leuw sikerre

Manindrau ka matat toga

Sibaoe babara ka manna

Masiperoe sita (bis).

Konan kai itjo bai

Maigi nen kinegen

Sioeloei arat toga nen

Aragalaknan siboboi en

Masiala oektoeknia (bis).

Konan kai itjo bai

Ekeuw leuw isogai

Masiake poesougat bacham

Ikau silinia angkat bacham

Boeroeboeroe ta lepa (bis).
Komt toch hier, ziet eens

het Kind dat slaapt

in den stal der huisdieren

aan zijn zijde is Maria

de vrome moeder.

Komt toch hier, ziet eens dat licht op het veld dat de engelen voortbrengen hoe schoon is hun gezag onze Heer Jezus is er.

Komt toch hier, ziet eens de herders bij de schapen lang hebben zij gewacht eerst dezen avond vonden zij

[Hem.

die hun hart vroolijk maakt.

Komt toch hier, ziet eens ook de priesters (wijzen) komen om het kind te aanbidden dat pas van den hemel kwam om ons heil te brengen.

Kom toch hier, ziet eens die velen nu

die de leer van het kind volgen ze hebben neergelegd het ver[geefsche om zegen te halen.

Komt toch hier, ziet eens ook $\mathrm{U}$ roept $\mathrm{Hij}$ om voor Uwe treurigheid vroolijkheid te geven. altijd, eindeloos.

Literatuur. Over de Mentaweische literatuur valt niets te vermelden. Het volk heeft geen letterschrift, geschriften bestaan 
er niet, de schrijfkunst is eerst sedert kort eigen geworden aan de jongelingen, die onderricht genoten hebben op de Zendingsscholen. Wel kennen de menschen bij mondelinge overlevering verschillende legenden en verhalen, zelfs gedichtjes en raadsels.

Kleeding, De kleeding der Mentaweiers is al zeer primitief. Zij gaan bijkans naakt; de mannen dragen slechts een heupband

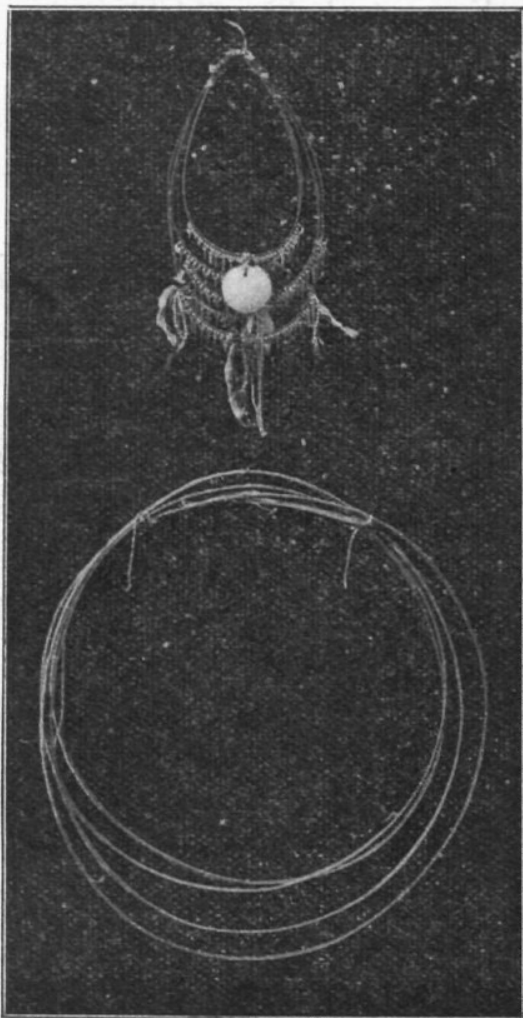

Halsketting en gordel van gespleten rottan.

Schaal $1: 8$. van geklopt boomschors ${ }^{1}$ welke band tevens schaamgordel is. Sommigen dragen om het middel bovendien een gordel, bestaande uit een langen reep roodgekleurde rottan, die eenige malen om het lichaam gerold wordt. Deze gordel, soms bezet met kralen, dient wel tot bergplaats voor mes of dolk, of wordt versierd met bloemen, bladeren, gekleurde lapjes, schelpen, spiegeltjes, muntstukken, metalen voorwerpen, enz.

$\mathrm{Om}$ den hals dragen de mannen halssieraden, eveneens vervaardigd van reepen roode rottan, die ook weer veelal bezet zijn met kralen, terwijl er op regelmatige afstanden kleine, puntige stukjes parelmoerschelp aan hangen. Meestal dragen zij 5 à 6 van die reepen tegelijk, zoodat een groot gedeelte van hals en borst er mede bedekt wordt. De bovenste reep draagt soms, bij wijze van medaillon, een rond, uitgetand stuk parelmoerschelp, ter grootte ongeveer

1 De boomschors wordt geklopt, uitgewasschen en daarna gedroogd. Zoodoende krijgt men iets, dat wel wat van geweven stof heeft. Groote stukken van dusdanig bereid boomschors worden wel roor ligmatjes gebruikt. 
van een gulden. Aan het halssieraad komen dikwijls ook de versierselen te hangen, als hierboven bij den gordel vermeld; alleen bloemen en bladeren vinden hier geen plaats.

Vele mannen dragen ook halskettingen van geregen kralen. Deze kralen van glas (en enkele maal van steen) worden in groote hoeveelheden ingevoerd, en vormen een gewild ruilmiddel. Het feit, dat de dooden ter ruste gelegd worden, voorzien van hunne kralen-versierselen, maakt, dat er een loopende omzet van dat artikel is.

Velen dragen tevens een amulet, die eenvoudig met een touwtje om den hals hangt. Die amulet bestaat grootendeels uit kleine blaadjes of kruiden. gewikkeld in een stukje doek, en omsnoerd met dunne bindrottan.

Sommigen versieren zich pols of bovenarm met armbanden, bestaande uit eenige windingen van koperdraad, soms ook van ijzerdraad. Metaal over het algemeen vertegenwoordigt in het oog van den Mentaweier kracht, en zoo wanen de dragers van metalen ringen aan die voorwerpen kracht te ontleenen.

Als hoofddeksel draagt de man een hoed, ruw samengebonden uit het blad van den sagopalm. Ook wordt een hoed gedragen, vervaardigd uit de bladscheede van den niboengpalm, welk materiaal geen water doorlaat. Deze hoed, die ongeveer $80 \mathrm{cM}$. lang is, dient tevens tot regenscherm. Het eerstgenoemde hoofddeksel wordt ook door de vrouwen gedragen.

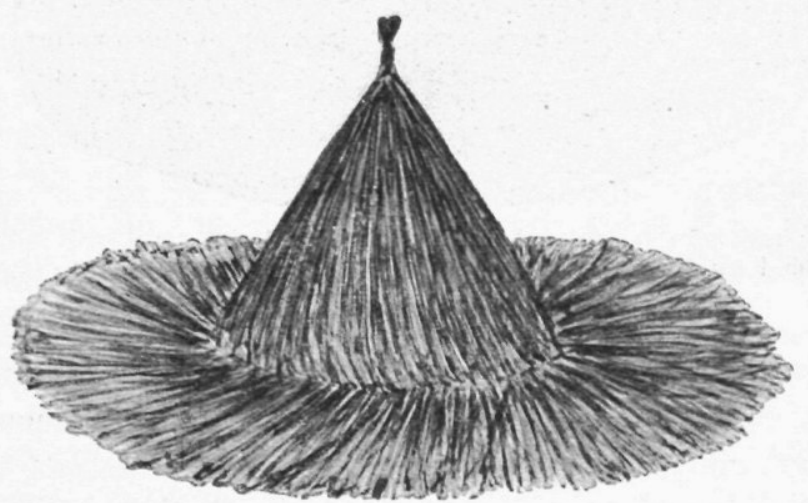

Hoed uit palmblad. Schaal 1:8.

De garde-robe der Mentaweische vrouwen is slechts weinig uitgebreider dan die der mannen. De vrouwen dragen om de heupen een doek, die niet verder reikt dan tot de knie. Verder 
dragen ook zij halsversieringen, doch alleen bestaande uit kralenkettingen. Hoe meer strengen kralen, hoe mooier; de halstooi is meermalen nog dikker dan een arm. Armbanden worden ook
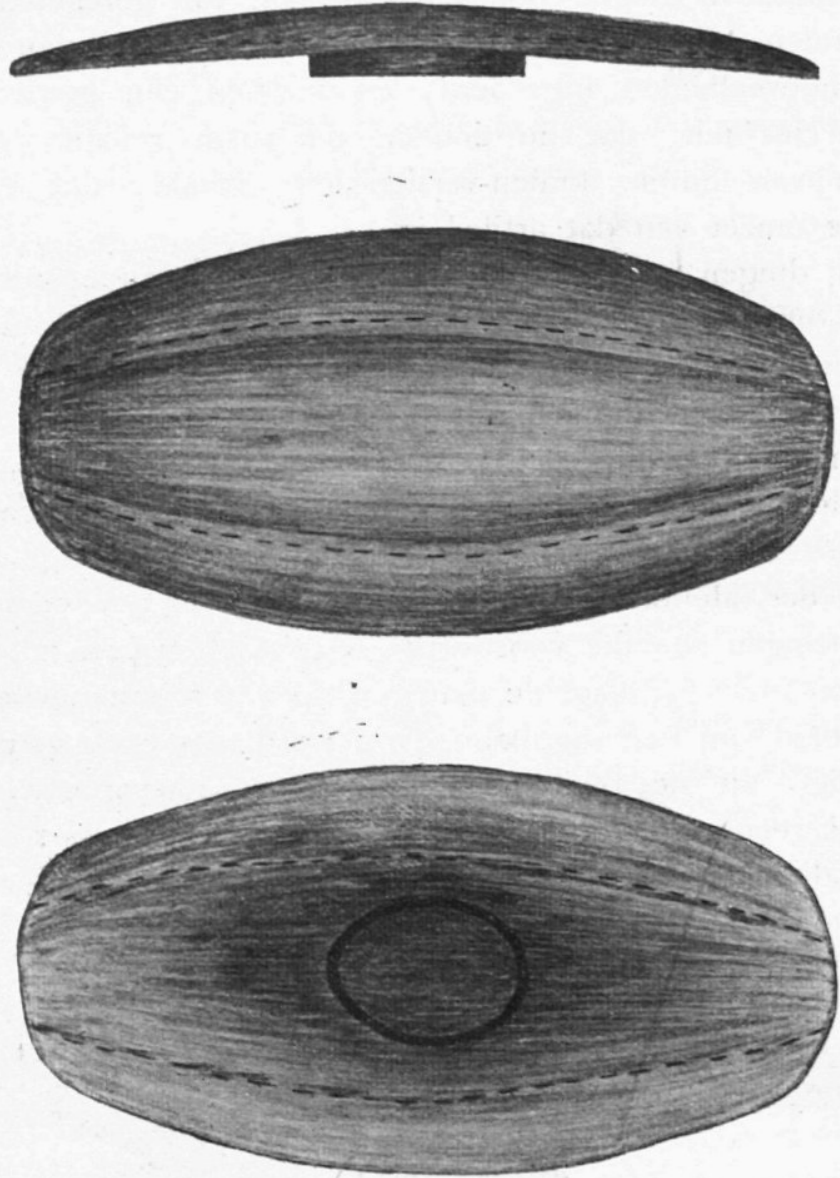

Hoed uit bladscheede van den niboengpalm. Sehaal 1: 10 . (Zij-, boven- en benedenaanzicht.)

door vrouwen gedragen, doch niet zoo veelvuldig als door mannen.

De vrouwen dragen denzelfden hoed als de mannen, doch alleen dien uit palmbladen vervaardigd.

Wanneer de vrouw niet hare huiselijke bezigheden verricht, dan draagt zij een tot even over de knieën reikend rokje, gemaakt uit pisangblaren, die daartoe aan reepen uitgerafeld worden. Zoo'n rok, bestaande uit verscheidene lagen van die blaren, is vrij dik en makt den indruk van den rok eener 
balletdanseres. De uitgerafelde pisangblaren doen op het eerste gezicht denken aan alang-alang. Naarmate deze rok langen tijd gedragen is, verschiet de frissche, groene kleur, en wordt het kleedingstuk vervangen door een nieuw.

Begeeft de vrouw zich buiten haar kampong, dan bedekt zij zich het bovenlijf met een kleedingstuk, dat uit hetzelfde materiaal bestaat als

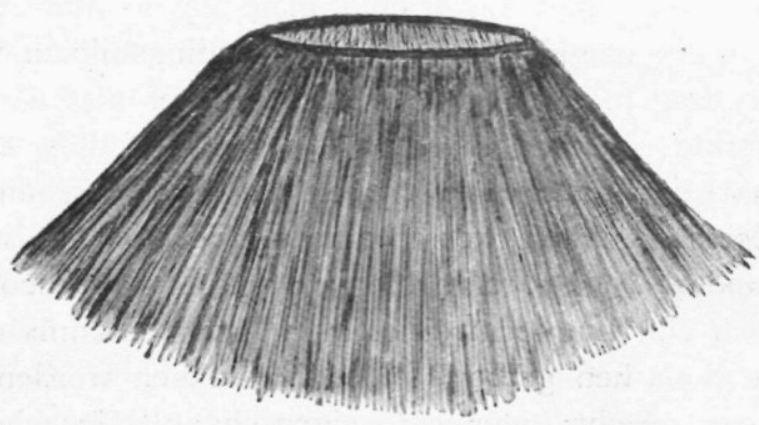

Vrouwenrok uit blaren. Schaal 1:15. de rok, en kruiselings over borst en schouders geslagen wordt.

De mannen dragen over het algemeen halflang haar, dat naar achteren gestreken, en in een wrong bijeengehouden wordt. In het haar dragen zij tot versiering bloemen, blaren, en soms welriekende kruiden. Enkele mannen dragen ook wel het hoofdhaar kort. Snor of baard draagt de Mentaweier niet, soms ziet men een enkelen grijsaard met een dunne sik, waarvan de haren te tellen zijn.

De vrouwen dragen lang haar, in een wrong boven op de kruin, terwijl het van voren gescheiden is.

Het hoofdhaar onderhouden de Mentaweiers al zeer slecht; een kam is bij hen een vrij onbekend voorwerp.

Vele vrouwen hebben in de oorlellen groote gaten, die echter nooit voorzien worden van oorknoppen.

De Mentaweier, zoowel man als vrouw, tooit zich gaarne met bloemen, vooral in het haar en dikwijls ook achter de ooren. Het meest worden daartoe gebruikt de kembang sěpatoe en de gandasoeli.

Bij enkele gelegenheden wrijft de Mentaweier zich soms lichaam, aangezicht en handen in met koenir-wortel (fibraurea chloroleuca) waardoor hij er uit ziet, als ware hij geel geschilderd.

Kleine kinderen loopen eenvoudig geheel naakt, soms dragen ze een amulet om den hals, een arm- of voetring, en een enkel strengetje kralen.

Aan reinheid van het lichaam doet de Mentaweier niet veel; wel baadt hij geregeld in de rivier, doch het gebruik van zeep kent hij niet. 
Ook het gebit verzorgt hij slecht; de snij- en hoektanden worden in driehoekigen vorm uitgevijld.

Is hiermede het origineele toilet van de Mentaweiers beschreven, niet onvermeld mag blijven, dat zij in den laatsten tijd een neiging hebben, om kleedingstukken van geweven stof te dragen. Men denke hierbij echter niet aan behoorlijk afgewerkte, nieuwe kleeren. $\mathrm{Zij}_{\mathrm{ij}}$ trekken alles aan, wat zij maar machtig kunnen worden, en dat zijn doorgaans oude, afgelegde kleedingstukken, zoowel van Europeanen als van inlanders. Bijzonder welkom zijn afleggers van Europeanen; deze menschen toch zijn hunne meerderen in kracht, kennis en beschaving, en de door hen gedragen kleedingstukken worden door den Mentaweier geacht, genoemde eigenschappen in zekere mate op hem te kunnen overdragen. Een oude soldatenjas b.v. doet meer opgeld dan een splinternieuwe burgerjas. Hoe komiek een "aangekleede» Mentaweier er uit kan zien, laat zich denken!

Geen wonder, dat de op de Mentawei-eilanden handelende Maleiers en Chineezen zich beijveren, veel oude kleeren als ruilmiddel in te voeren.

Tatouage. De Mentaweier tatoueert zich over het geheele lichaam: hoofd, borst, rug, buik, armen, handen, beenen en dijnen. Zoowel mannen als vrouwen zijn getatoueerd, zonder uitzondering, doch de tatouage der vrouwen is niet zoo ver gedreven als die der mannen. Het proces begint tegen het aanbreken der puberteitsjaren, verloopt geleidelijk, en is afgeloopen, wanneer de persoon volwassen is.

Dat niet het geheele lichaam ineens getatoueerd wordt, laat zich begrijpen, indien men weet, dat het tatoueeren een vrij pijnlijke geschiedenis is. Men gebruikt hierbij een scherpe metalen stift, die onder een hoek van ongeveer $60^{\circ}$ is bevestigd aan een houten steel. Dit instrument wordt met de metalen punt op de huid geplaatst, en, al kloppende met een stuk hout, worden de tatouage-lijnen in de huid geploegd. De bloederige strepen worden ingewreven met een mengsel van suikerrietsap en roet. Min of meer ernstige verzweringen zijn soms het gevolg van die handelwijze; wanneer echter de wond geheeld is, dan vertoonen zich op de huid blauwzwarte strepen.

De tatouage bestaat uit rechte en gebogen lijnen, benevens drie figuren: spiraal, zon en vogel. Deze figuren vormen 
tevens de eenige motieven in de Mentaweische ornamentiek.

Hier volgt een overzicht van de strepen en figuren, die bij de tatouage voorkomen.

$1^{\mathrm{e}}$. Over den buik, op en onder den navel, van links naar rechts, een paar evenwijdige gebogen lijnen, met naar beneden loopende, korte, franjeachtige strepen.

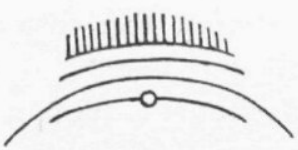

$2^{\text {e }}$. Van den navel af, recht naar boven loopende tot aan de borstholte, een rechte streep.

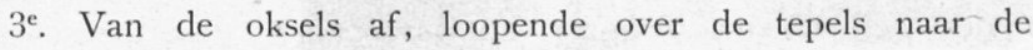
heupen, een gebogen streep.

$4^{\mathrm{e}}$. Ter weerzijden van de sub $2^{\mathrm{e}}$ vermelde rechte streep, even onder de borstholte, een figuur, voorstellende een vogel (haan) of een zon. '
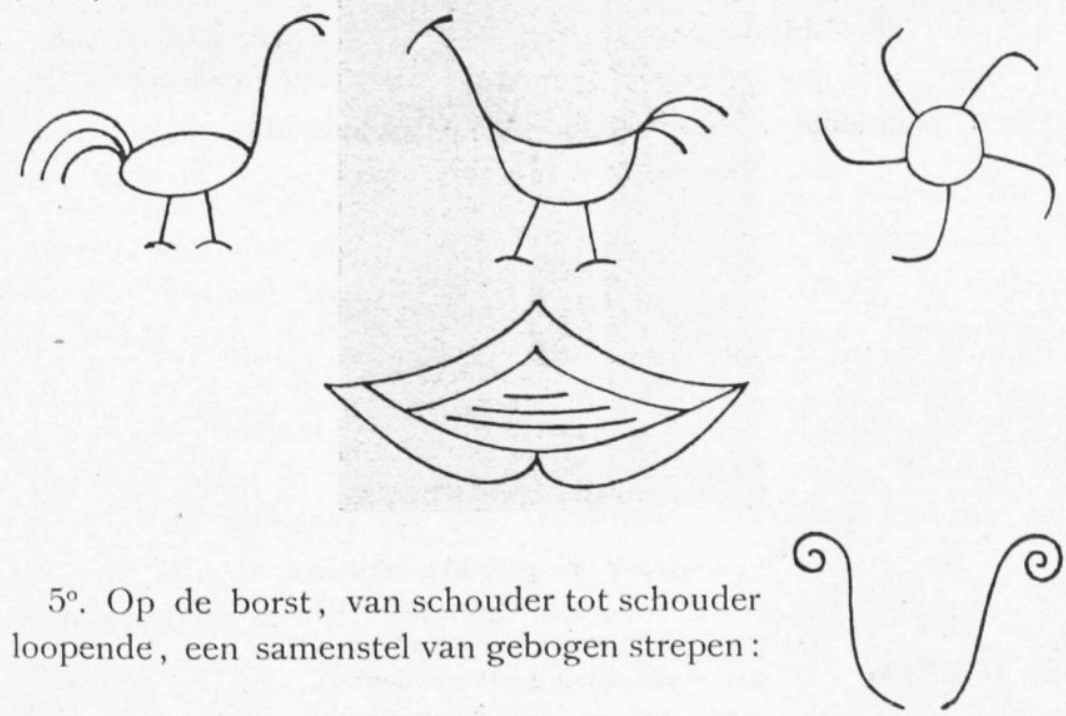

$5^{\circ}$. Op de borst, van schouder tot schouder loopende, een samenstel van gebogen strepen:

$6^{\text {e. }}$ Van de schouders over de keel naar de kin een of twee gebogen strepen.

$7^{\mathrm{e}}$. Van de kin, over de wangen, naar de ooren, een of twee gebogen strepen, soms eindigende in een spiraal.

8 . Langs de ruggegraat een rechte streep, met korte dwarsstrepen op de rugwervels.

$9^{\mathrm{e}}$. Over de lengte van den arm een of twee strepen.

$10^{\mathrm{e}}$. Over den handrug vijf strepen, doorloopende over de

1 Niet onmogelijk is het, in dit motief een verbasterd swastika-figuur te zoeken. 
vingers naar de nagels; de vingersstrepen hebben korte dwarsstrepen.

$11^{\mathrm{e}}$. Op den buitenkant van het dijbeen een lengtestreep, voorzien van dwarsstrepen.

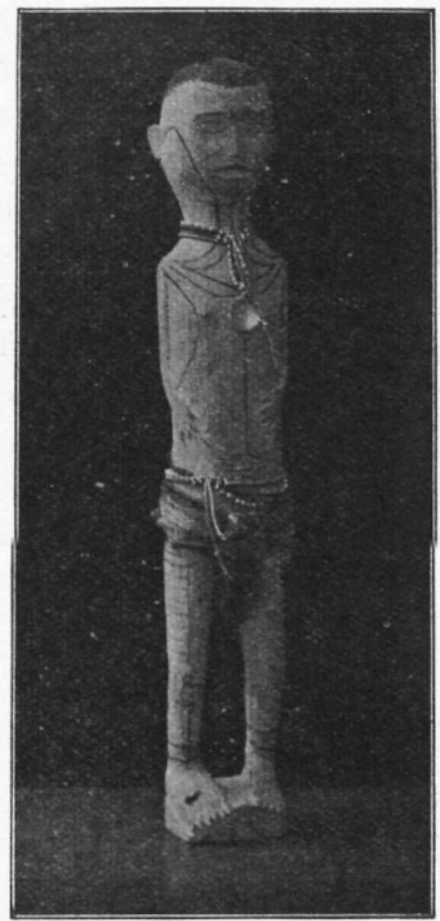

Houten pop, die gebruikt wordt als drijver op vischnetten, om een goede vangst te erlangen. De aankleeding geeft een denkbeeld van de kleedij der Mentaweiers, terwijl ook enkele tatouage-strepen goed zichtbaar zijn.

1 ware grootte.

(Coll. Koloniaal Instituut.)

Wapens. De voornaamste wapens van den Mentaweier zijn pijl en boog. De boog wordt vervaardigd van een buigzame houtsoort, soms ook van niboeng, en is een eenvoudige lange stok van $\pm 1.60 \mathrm{M}$. lengte, eenigszins ellipsvormig gebogen. Versiering of kunstsnijwerk wordt bij dit wapen niet aange- 
troffen, alleen bevat het eene uiteinde een rondgaande gleuf, en het andere eenige inkepingen, bestemd om de lusvormige uiteinden van het koord op te nemen.

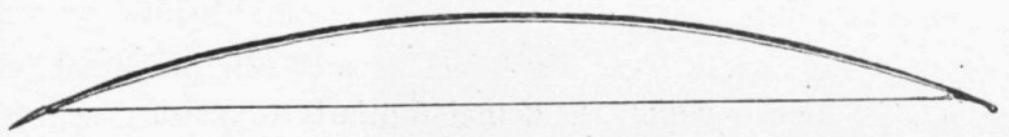

Boog. $\pm \frac{1}{15}$ ware grootte.
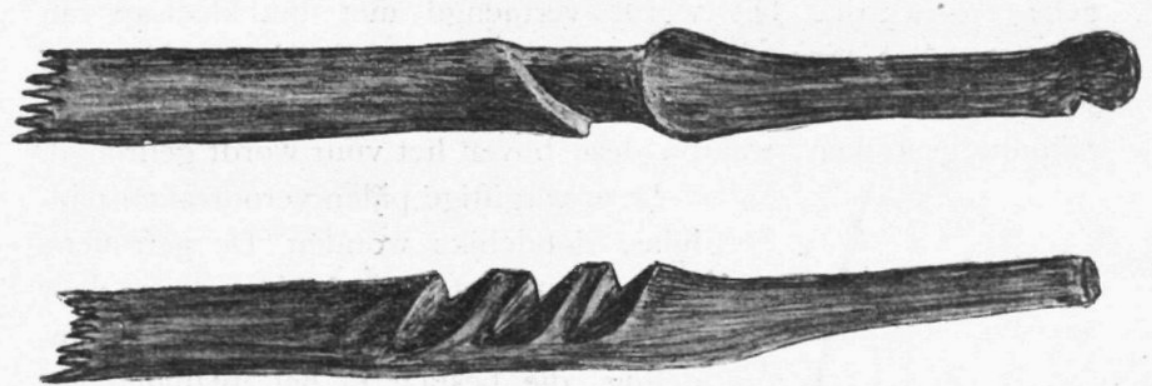

Uiteinden van een boog. $\pm \frac{3}{4}$ ware grootte.

Dit koord wordt gedraaid uit reepen boomschors, en daarna gepekt. Het pek verkrijgt men, door de bast van een verfhoutboom (Maleisch kajoe oebar) fijn te stampen en uit te persen, waardoor een roode, kleverige stof ontstaat, die bij opdrogen zwart wordt en niet meer plakt.

De pijl bestaat uit een steel en een losse punt. De lengte van den steel is \pm 60 c.M., die van de punt \pm 25 c.M. De steel wordt gemaakt van een palmstengel, de punt van niboeng. De pijlpunt is aan beide einden aangepunt, ze wordt los in den steel gestoken, die daar ter plaatse tegen uitscheuren beschermd wordt door een omwinding van dun touw en door een dun laagje pek.

Op eenigen afstand van het uiteinde heeft de pijlpunt een rondgaande gleuf, en is bovendien nog op één of twee plaatsen geringd.

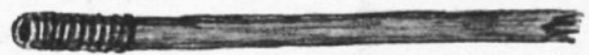

Pijlpunt en uiteinde van den steel. Schaal 1:4.

Treft nu de pijl een mensch of een aap (de Mentaweiers jagen veel op apen, welker vleesch zij gaarne eten), dan is de eerste impulsie van den getroffene, de pijl uit te trekken. Daarbij bestaat veel kans, dat aan den steel gerukt wordt; deze 
laat los, doch de punt blijft in de wond zitten. Wordt nu aan de punt getrokken en gewrongen, dan breekt ze bij den ring of de gleuf af. Een stuk pijlpunt blijft dus altijd in de wond steken.

De pijlpunt wordt vergiftig gemaakt met een preparaat, dat bestaat uit het sap van de oemai (antiaris toxicaria; een vergiftige plant, die door de Mentaweiers voor dit doel opzettelijk gekweekt wordt). Dit wordt vermengd met het kleefsap van den ingas-boom en met fijngewreven lombok rawit (de scherpste soort Spaansche peper, die bestaat). Dit mengsel wordt aan de pijlpunt gestreken, waarna deze boven het vuur wordt gedroogd.

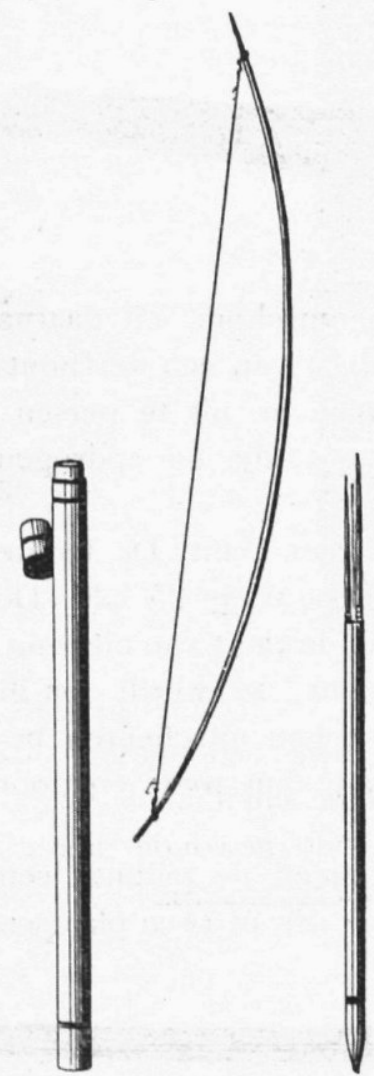

Boog, groote en kleine pijlkoker.

$\frac{1}{16}$ ware grootte.

Deze vergiftige pijlen veroorzaken pijnlijke, doodelijke wonden. De getroffene kan slechts het leven eraf brengen, door een oogenblikkelijke, zaakkundige behandeling, die bestaat in het uitzuigen der wond (middels een zuigglas) en injecties of natte omslagen van kaliumpermanganaat, natuurlijk na voorafgaande stremming van den bloedsomloop, om het bloed te verhinderen, verder het lichaam binnen te dringen.

Het vergif is gemakkelijk van de pijlpunt te verwijderen, door deze eenigen tijd in water (liefst in stroomend water) te laten weeken.

In het hanteeren van pijl en boog heeft de Mentaweier groote vaardigheid. Kinderen ziet men spelenderwijs zich in het schieten oefenen, waarbij èen bijzondere pijl met stompe punt gebruikt wordt.

De pijlen worden geborgen in een bamboe-koker, die wel waard is, nader beschreven te worden, omdat men hierbij een van de weinige uitingen van Mentaweische sierkunst aantreft. De sluitdop (Coll. Koloniaal Instituut.) wordt n.l. bedekt met een laagje pek, en daarin wordt van glazen kralen een figuur aangebracht, bestaande uit een zeshoek. 
Verder vindt men op den sluitdop meestal een met pek opgekleefd stukje spiegelglas of glimmend parelmoer, dat een oog moet voorstellen, hetwelk geacht wordt gezichtsvermogen mede te deelen aan de in den koker geborgen pijlen, opdat deze met zekerheid

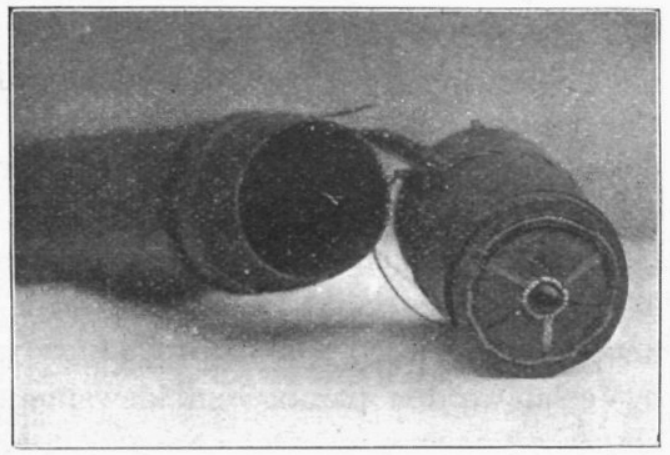

Versierde sluitdop van een pijlkoker. $\pm \frac{1}{5}$ ware grootte. doel zullen treffen.

$\mathrm{Om}$ visch te schieten, gebruikt de Mentaweier een ongeveer 1.5 M. langen pijl.
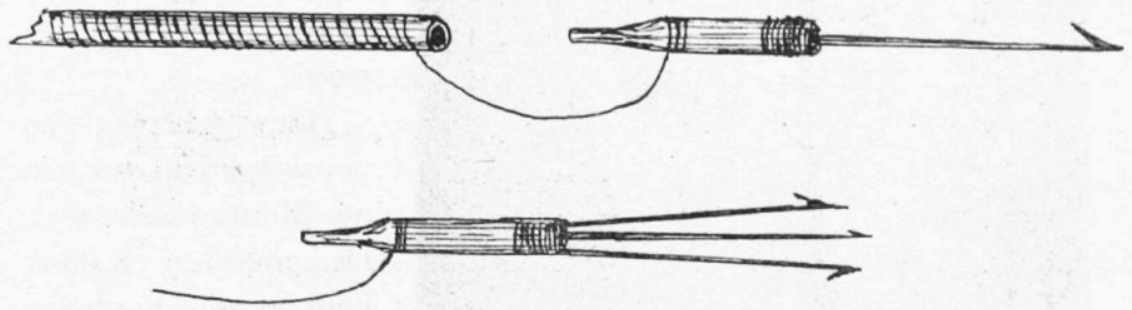

De punt bestaat uit een stukje rond hout, waaraan een ijzeren of koperen weerhaak (veelal een drietand.)

Deze punt sluit bij wijze van dop in den steel. Om den steel. is een lang vischkoord gewikkeld, dat met één uiteinde is vastgebonden aan den punt, met het andere aan den steel zelfWordt een visch getroffen, dan schiet het gewonde dier al

Lans en vischpijl.

$\frac{1}{20}$ ware grootte.

(Coll. Koloniaal Instituut.)

spartelend naar de diepte, waarbij de punt uit den steel gaat. Dan wikkelt zich de vischlijn van den steel af, welke laatste, al drijvende, de plaats aanduidt, waar de visch zich bevindt. 
Men roeit dan naar die plaats toe, grijpt den steel, en haalt den buit aan de lijn binnen.

De blanke wapens van den Mentaweier zijn nagenoeg dezelfde als van den Sumatraanschen Maleier, n.l. klewangs, parangs, dolkmesjes, (in scheede) en lansen. Een specifiek Mentaweisch wapen is de palité, een tweesnijdende, breede dolk in scheede, De greep is nagenoeg in halven cirkelvorm gebogen, en eindigt in een scherpe punt. De palité wordt gedragen rechts in den heupband.

Veelal worden parangs en klewangs zonder greep ingevoerd,

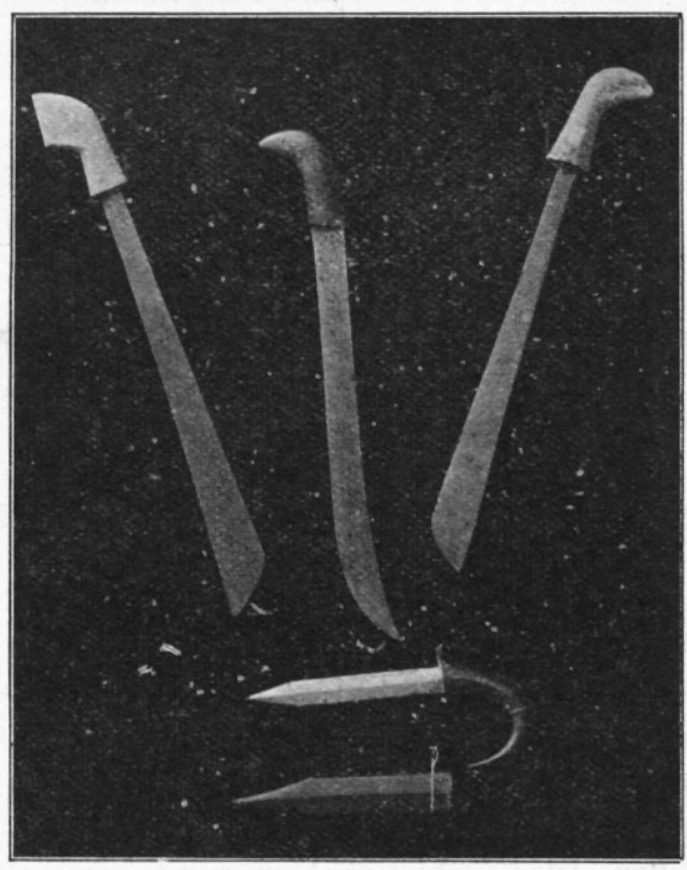

boven: 3 Mentaweische parangs (kapmessen), het middelste met greep van ngara-hout. beneden: palité met scheede; greep en scheede van ngara-hout. To ware grootte.

(Coll. Koloniaal Instituut.) terwijl de Mentaweier zelf een greep daaraan maakt, zeer ruw gesneden uit hout. Aan de greep van de palité, meestal uit ngara-hout gesneden , wordt meer zorg besteed.

Het gebruik van vuurwapenen kennen de Mentaweiers niet. De meesten hunner hebben zelfs nooit een geweer zien of hooren afschieten. Wel is hun bekend, waartoe een vuurwapen dient, en zoo noemen zij een geweer si betoeit (betoe $=$ damp, rook), d. w. z. datgene, waar rook uitkomt.

Merkwaardig is ook het schild der Mentaweiers, doch, zooals reeds werd opgemerkt, dit wordt alleen gebruikt door de lieden van het eiland Siberoet.

Wijze van oorlogvoeren. We komen nu vanzelf tot de bespreking van de wijze van oorlogvoeren der Mentaweiers. 
Wanneer er een veete ontstaat, die met de wapens beslecht zal worden, dan wordt in den boezem der beide partijen de zaak lang en breed besproken. Is men van meening, dat een krijg ongewenscht is, of tot een nederlaag zal leiden, dan wordt van den strijd afgezien, en verlaat die partij haar woonplaats, om zich elders te vestigen. Alleen als beide partijen zich tegen elkaar opgewassen gevoelen, wordt de strijd aanvaard.

Er gaat een verhaal van lieden van Siberoet, waar twee partijen elkaar den oorlog verklaard hadden, die den strijd beslechten niet met de wapens, maar door een wedstrijd in vaardigheid in arbeid. Dit ten bewijze, dat alleen naar de wapens gegrepen wordt als het niet anders kan.

De bewoners van Siberoet staan ook thans nog in een kwaden reuk bij de overige Mentaweiers. Volgens de overlevering hebben lieden van Sipora zoowel als van de Pageh-eilanden nadat zij Siberoet verlaten hadden, dat eiland nog wel eens bezocht, doch zouden zij van die reis met bebloede koppen teruggekomen zijn. Tegenwoordig bezoeken de lieden van de Pageh-eilanden en van Sipora elkaar wel onderling, maar op Siberoet komen zij niet.

Een voorbeeld hoe de vreedzamen zich van de strijdlustigen afscheiden werd in 1907 gegeven, toen de kampong Taikako (Noord-Pageh) den strijd aanbond tegen ons gezag. Na lang wikken en wegen besloot de meerderheid, den strijd te aanvaarden. De minderheid was van meening, dat men tegen de soldaten van de kompenie toch niet opgewassen zou zijn (sommigen hadden vernomen van de uitwerking onzer geweren, in hun oogen, onbegrepen helsche voorwerpen) en dat voor elken gesneuvelden soldaat er tien anderen in de plaats zouden komen. Die minderheid verliet de kampong Taikako en stichtte een klein half uur stroomafwaarts de rivier een nieuwe kampong, Silaoenan geheeten. Zooals de afgescheidenen voorzien hadden, geschiedde. Taikako moest den strijd spoedig opgeven en zich onderwerpen.

De wijze, waarop Taikako tegenstand bood, duidt ook al niet op energie of bedrevenheid in het oorlogvoeren. De Taikakorivier werd door de bevolking beneden-strooms versperd, doch die versperring werd niet verdedigd. Toen onze bewapende sloepen-flottielje de rivier opvoer en bij de versperring aankwam, kon deze zonder stoornis opgeruimd worden. Van de hooge, begroeide oevers af was de gelegenheid schoon geweest, Dl. 70 . 
onze troepen te beschieten. Waarschijnlijk heeft men gedacht dat de versperring voldoende zou zijn, om onze troepen tot den aftocht te dwingen. Toen men zag, dat de flottielje doorvoer, ondanks de versperring, kreeg men ontzag, en het gevolg was, dat de kampong Taikako ontruimd werd; de bevolking week uit naar hare stroomopwaarts gelegen ladangs; de onzen betrokken een bivak dicht bij de kampong, en trachtten te vergeefs voeling met de bevolking te krijgen. Eindelijk wisten onze troepen van Silaboe uit (Westkust van Noord-Pageh) de uitgewekenen in den rug te bereiken. De Mentaweiers vonden zulks zóón staalt.je van volharding en durf, dat ze dadelijk het hoofd in den schoot legden, en zich gewonnen gaven.

Hieruit blijkt wel, hoe onbedreven dit volk in het oorlogvoeren is.

Vermelding verdient, dat de bevolking van de nieuw gestichte kampong Silaoenan, onze beste onderdanen van de Pageheilanden zijn. Hun heerendienst-arbeid is altijd keurig in orde en op tijd klaar; hun voortvarend kamponghoofd voert zelfs eigener initiatief allerlei werken uit.

Een bewijs, dat de bewoners der Pageh-eilanden den strijd liever ontwijken dan dien zoeken, ligt voorts hierin, dat zij hun kampongs nooit aan de zeekust bouwen, doch altijd een eind stroomopwaarts. Van de zee uit is dan ook geen Mentaweische kampong waar te nemen.

Werktuigen en gereedschappen. De werktuigen van den Mentaweier zijn zeer primitief. Onbekend als hij is met steen- of metaalbewerking, is hij, wat zijn werktuigen en het grootste gedeelte zijner gereedschappen betreft, aangewezen op hetgeen van Sumatra ingevoerd wordt. Met zijn parang bewerkt hij het hout. Enkele Mentaweiers bezitten zaag, beitel of vijl. Een werktuig, waarmede de Mentaweier wonderen verricht, is de stalen bělioek, ook bij de Maleische volken bekend.

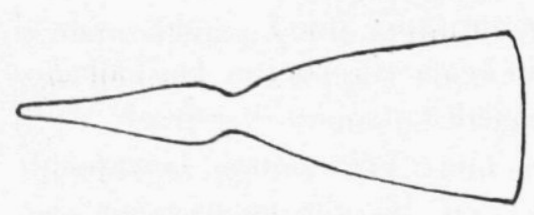

De bělioek is een soort bijl, welker achtereinde in pik-vorm eindigt, en die ter hoogte van de verzwakking met bindrottan aan een flauw gebogen steel gesnoerd wordt. Door de bělioek $90^{\circ}$ om haar lengte-as te wentelen, kan zij als dissel gebruikt worden. 
Met dit werktuig velt de Mentaweier de zwaarste boomen en verwerkt hij die tot balken, planken, ja, tot prauwen. Bij het maken van planken gebruikt hij houten wiggen, die hij in den gevelden boom drijft; de zoo verkregen ruwe planken worden met de bělioek, als dissel gebruikt, bijgewerkt.

Ook kent de Mentaweier het gebruik van de patjol (inlandsche hak-schop), doch hiermede is hij niet zeer handig. Het gebruik hiervan heeft hij leeren kennen door het verrichten van heerendiensten, waarbij hem patjols ten gebruike werden afgestaan. De patjol valt echter bij hem niet zoodanig in den smaak, dat hij zich die zal aanschaffen voor eigen werk, b.v. bij ladangbouw.

Verder gereedschap van den Mentaweier zullen we vanzelf leeren kennen bij de bespreking van de inrichtingen der huizen, de jacht, de vischvangst, enz.

Huizenbouw. Alvorens de bouworde en de inrichting der huizen te beschrijven, zal ik trachten, een indruk te geven van den aanleg der kampongs.

De kampongs worden zonder uitzondering gebouwd aan een rivier, op vrij grooten afstand van de monding. Elke kampong is onafscheidelijk gebonden aan een rivier, omdat de bevolking het water daarvan behoeft voor drink- en badwater. Het gebruik van zelfs de primitiefste waterleidingen kent de Mentaweier niet. Men treft dan ook in het diepe binnenland, buiten het stroomgebied der rivieren, geen kampongs aan, evenmin daar, waar de rivieren onbevaarbaar worden voor de kleine prauwtjes. Het is voorts een bepaalde eisch, dat de kampongs aan een bebaarbaar gedeelte van de rivier liggen, omdat de Mentaweier bijna uitsluitend het verkeer over water neemt. Verkeerswegen over land kent hij in zooverre, dat ons bestuur op de eilanden wegen heeft laten aanleggen, die de kampongs onderling verbinden; van die wegen maakt hij nog weinig gebruik.

De Mentaweische prauwen bestaan uit uitgeholde boomstammen, die slechts zeer weinig diepgang hebben; zoodoende kunnen de kampong dikwijls hoog stroomopwaarts liggen.

In de kampongs ontwaart men niets van eenige regelmaat in de wijze van plaatsing der woningen; deze staan kris en kras door elkaar. Elke kampong heeft haar "oemah sabeoe" of groot huis, een vereenigings- en bedehuis tot algemeen gebruik. Om 
die «oemah» zijn de woningen gegroepeerd, terwijl ons bestuur getracht heeft, zoo goed en zoo kwaad als het ging, door dien chaos een behoorlijken weg aan te leggen.

Is een kampong verdeeld in oemah's, dan heeft elke oemah zijn oemah sabeoe.

Het zal opvallen, dat "oemah» tegelijk een abstract en een concreet begrip uitdrukt; in het eerste geval beteekent het een federatie, een soort groote familie, in het tweede geval het gemeenschappelijke huis, dat als het middelpunt van die federatie te beschouwen is.

Hier en daar ziet men in de kampong wat sierboompjes (crotons) geplant, benevens enkele bloemdragende planten of heesters.

De Mentaweische woningen staan zonder uitzondering op palen; de vloer komt 1 à 2 M. boven den beganen grond. Stijlen, bintbalken, enz. bestaan uit rondhout, de bedekking en veelal ook de omwanding, bestaat uit atap. Voor de omwanding worden ook wel boomschors, peloepoeh (opengelegde en platgeslagen bamboe) of planken gebruikt. De vloer bestaat uit planken, of uit latten van bamboe of niboeng.

De nok van het tweevlakkige dak is soms in het midden eenigszins ingezonken.

De toegang tot het huis wordt gevormd door een schuin staanden boomstam, voorzien van inkepingen, voor het plaatsen der voeten. Soms ook door een eenvoudig laddertje.

Het eerst komt men in een ruimte, die van voren open is,

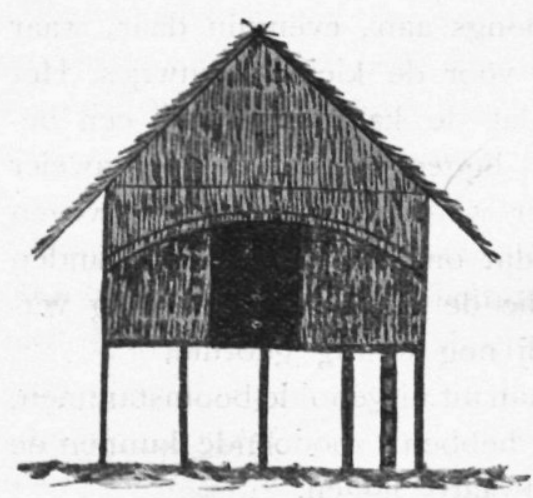
een soort voorgalerij. Van den nok af tot ongeveer manshoogte heeft men een soort gevel van atap, beneden eindigende in een flauwe bocht.

Bedoelde vóór-ruimte geeft den bewoners gelegenheid hunne bezigheden te verrichten; binnen in de woning toch heerscht een sombere duisternis wegens de afwezigheid van vensters. In die Profiel van een Mentaweisch woonhuis. voorgalerij ziet men dan ook den kookhaard staan, bestaande uit een plank of iets dergelijks, bedekt met droge klei of met asch, waarop een kookstelling van rondhout of bamboe, is geplaatst. 
Zelden bezit de Mentaweier metalen kookgerei; zijn vegetarisch voedsel, in hoofdzaak bestaande uit kladi en sago, wordt in dunne bamboes boven het vuur gepoft, terwijl hij zijn dierlijk

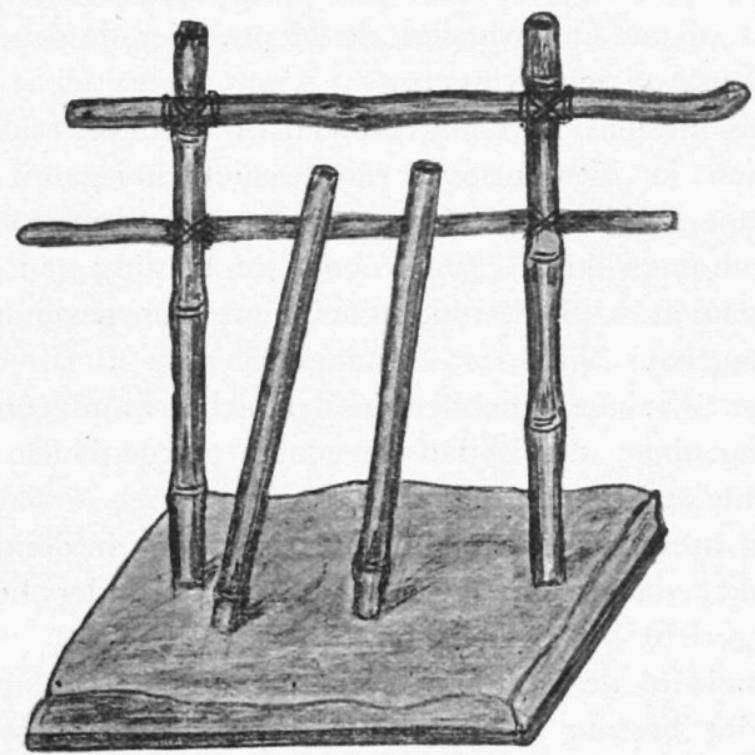

Mentaweische kookhaard, met 2 bamboes, waarin eten toebereid wordt. Schaal $1: 15$.

voedsel roostert. Op de asch of de klei wordt vuur aangelegd, waarna de haard gereed is voor gebruik.

Verder vindt men in de voorgalerij dikwijls een langwerpigen bak, uit latten vervaardigd, inhoudende levende krabben. Wanneer de Mentaweier, na volle maan, van de krabbenvangst huiswaarts keert, vult hij dezen bak, welks levende inhoud hem tot voedsel strekt tot de komende volle maan.

Nog is de inventaris niet compleet: manden, draagkorven, vischnetten, roeispanen, enz. worden vóór opgeborgen, terwijl kippen zich overal ongestoord nestelen. Ook ziet men er wel eens een korfkooitje met een vogel hangen. Tusschen de atap van dak en wanden worden dikwijls allerlei voorwerpen gestoken: uitgeblazen eierschalen, bosjes droge blaren, enz. Aan de stijlen hangen haken, doodskoppen, beenderen, enz. van apen en herten. Doch laatstgenoemde voorwerpen ziet men in de gewone huizen weinig; wel in groote hoeveelheid in de oemah sabeoe. 
Treedt men uit de voorruimte het huis binnen, dan gaat men door een lage, meestal smalle opening, gesloten door een deur van planken, boomschors of peloepoeh. Een zeer enkele keer is de planken deur versierd met grof houtsnijwerk, als regel een haan voorstellend. Ook versiert de Mentaweier de deur wel eens met gedroogde visschenvinnen.

Het huis bestaat inwendig uit één of twee vertrekken. Veel bevindt zich in die duistere ruimte niet: huisgerei, bamboekokers, wapens, kleedingstukken enz.; soms trommels van boomschors of houten kistjes (ingevoerd) tot berging van kleedingstof of vischnetten. Stof, roet en spinnewebben geven het geheel een vies aanzien.

Sommige woningen hebben in den achterwand een venstervormige opening; dit is dan de eenige gelegenheid, waardoor het daglicht kan binnentreden.

In het achtergedeelte van het huis is ergens in den vloer een gat gemaakt, dat is de W. C.! De ruimte onder het huis is meestal ingericht tot varkenshok.

De reinheid in de kampongs verkeert nog in een overgangstijdperk. Het bestuur heeft wel is waar strenge bestuursvoorschriften gegeven, doch van den Mentaweier, die eeuwen lang zich behagelijk gevoeld heeft in stof en vuil, maakt men niet plotseling een zindelijk mensch. Voor dat proces zijn jaren noodig.

Aan het houden van varkens onder de huizen maakt ons bestuur geleidelijk een einde. Deze dieren worden dan gehouden in stallen of kralen buiten de eigenlijke kampong.

De Mentaweische woning heeft veel overeenkomst met die der Karo-Bataks. Volz schrijft dienaangaande:

«Beim Karo-Haus ist genau wie bei den Mentawei-Häusern "an der Vorder und Rückseite ein offener Vorflur in der "Höhe des Hausbodens errichtet, der vor allem den Frauen "zum Aufenthalt bei ihren täglichen Arbeiten, zu denen sie "Licht brauchen - das Innere der Häuser ist bei dem "Mangel an Fenstern doch sehr dunkel - dient.»

Een onjuistheid hierbij is, dat men aan de achterzijde van het Mentaweische huis een "Flur» zou aantreflen. Als regel is dit niet het geval. Wel vindt men zoo'n portaal aan de achterzijde van de oemah sabeoe. 
De oemah sabeoe verloochent haar naam niet; het is met recht een groot gebouw, soms wel $40 \mathrm{M}$. lang. Zooals gezegd, is dat het middelpunt van een bevolkingsgroep, waarvan de leden zich rekenen tot ééne familie, niet in den zin van bloedverwantschap, doch bijeengehouden op de wijze van groepen die het totemisme kennen. Van het vereeren van een totem blijkt bij de Mentaweiers echter niets, noch in engeren zin bij de oemah's, noch bij het volk in zijn geheel.

Verscheidene andere volkstammen kennen het bezit van een gemeenschappelijk huis; ik wijs hier o.a. op de meunatha der Atjehers, de soerau der Maleiers; het longhouse der Irokeezen.

De bouwtrant van de oemah sabeoe wijkt in algemeenen zin weinig af van dien der gewone woningen, alleen is ze veel grooter en bezit ze meer vertrekken. De voorruimte of het voorportaal is dikwijls niet onder de kap van het huis gebracht. en dus niet overdekt. Meestal gaat men naar boven met behulp

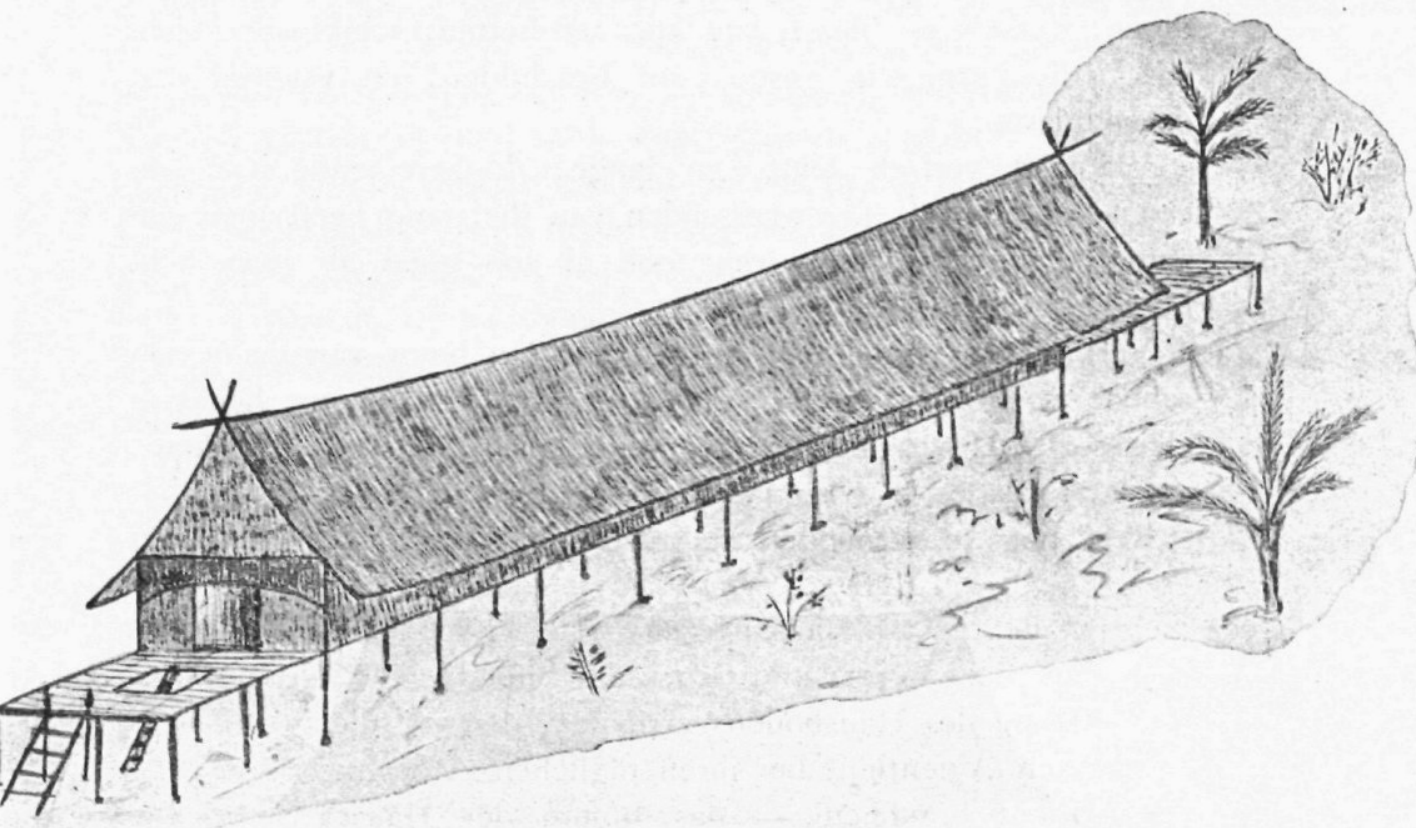

Oemah sabeoe.

van een ladder-trap, terwijl er onder den vloer van het voorportaal nog een tweede trap (ingekeepte boomstam) is, die door een vierkant gat, al of niet gesloten door een luik, toegang 
geeft naar boven. Deze tweede trap wordt alleen gebruikt bij ritueele diensten, en draagt den naam van "zielentrap".

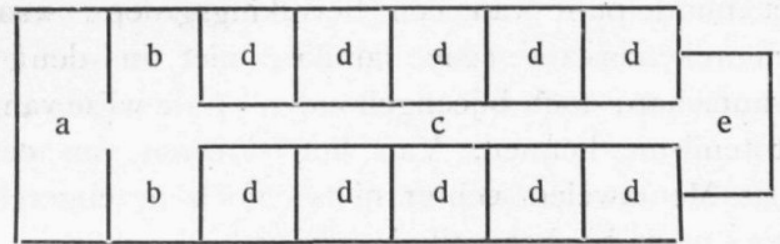

Platte grond van een oemah sabeoe: $\mathbf{a}=$ voorportaal;

b.b. = binnenruimte; $\mathrm{c}=$ gang; d.d. $=$ kamers; $\mathrm{e}=$ achterportaal.

Van het voorportaal komt men in een binnenruimte, die links en rechts kleine vensters heeft; doordien er geen deur is, ontvangt deze ruimte ook van voren licht, zoodat het er half duister is. Deze binnenruimte is een bergplaats van gewijde voorwerpen, gongs, trommen, huisraad, enz. Aan de zoldering, tegen de wanden, aan palen, hangen apenschedels, hertengeweien, beenderen, wervels en blazen van apen en herten, schildpadschalen, enz. Alles groezelig gerookt of beschilderd en versierd met droge blaren.

Van dat vertrek leidt een lange, donkere gang naar een een achterportaal. Ter weerszijden van die gang heeft men een aantal woonvertrekken, waar ook al zoo goed als geen licht binnendringt.

Vermelding verdient nog, dat aan den bouw van de oemah sabeoe veel zorg wordt besteed, zoodat het gebouw hecht in elkaar zit. Het wordt buitengewoon dicht ingedekt met atap, zoodat lekkages in geen jaren te vreezen zijn.

Rest nog te vermelden de prauwenloodsen. Om de prauwen

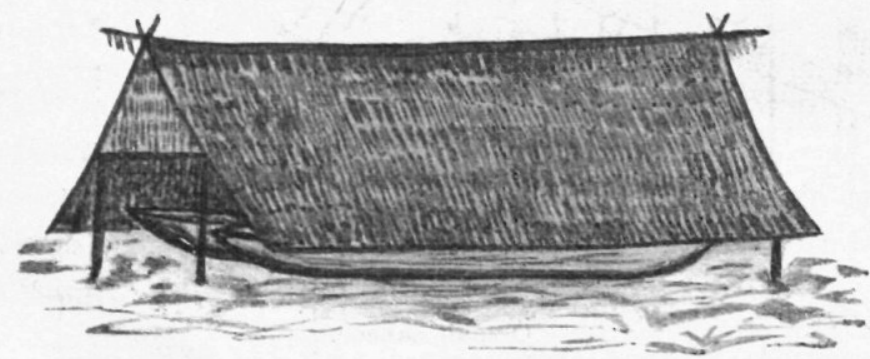

Prauwenloods.

niet bloot te stellen aan wisselende vochtigheid en zonnehitte (waardoor het hout zou barsten), worden ze geborgen in loodsen, 
die 1 tot 4 vaartuigen kunnen bevatten. Deze loodsen, waarvan de vloer gevormd wordt door den gewonen beganen grond, zijn uit den aard der zaak laag gebouwd. Zoo'n prauwenloods is een tweevlakkig afdak op palen; ze heeft geen zijwanden, doch het dak steekt links en rechts zoover over, dat het bijna den grond raakt.

Reeds is vermeld, dat de ruimte onder het huis bestemd is — of liever was - voor varkenshok. Varkens worden in grooten getale door den Mentaweier gehouden. Ook houdt hij er kippen op na, gedeeltelijk in de kampong, gedeeltelijk op de ladang, waar deze dieren een onderdak vinden in een ladanghuisje of wel in een kippenhok. Veelal echter gaan de kippen "op stok" in boomen of struiken. Een eigenaardigheid is het roepen van de kippen, hetzij om ze te voeren, hetzij om ze te vangen. Daarbij uit de Mentaweier eigenaardige, langgerekte geluiden, die op verren afstand te hooren zijn.

Hu isdieren. Varkens en kippen strekken den Mentaweier tot voedsel. Die dieren worden niet op de gewone wijze geslacht, maar gewurgd, of met een aangescherpte bamboe gestoken (varkens), waarbij inwendige verbloeding plaats heeft. Zijn bijgeloof verbiedt hem n.l., in de kampong bloed te laten vloeien. In verband daarmede is het dikwijls voor niet-Maleiers zeer lastig, kippen in de kampongs te koopen. Niet dan na de herhaalde verzekering, dat de gekochte kippen levend medegenomen zullen worden, kan de transactie tot stand komen.

Eenden worden slechts in zeer enkele kampongs aangetroffen.

Een veel voorkomend huisdier is de hond, die den Mentaweier groote diensten op de jacht bewijst.

Katten ziet men hoogst zelden in Mentaweische kampongs.

\section{HOOFDSTUK IV.}

Godsdienst, bijgeloof, gewoonten en gebruiken, pantang en poenèn, verbodsbepalingen, zedelijkheid, afgestorvenen, opvatting van

natuur en natuurkrachten, geneeskunde, volkskarakter

en volkseigenschappen, sagen en overleveringen.

Godsdienst, bijgeloof. Onder de Mentaweiers heerscht volslagen heidendom. Hun godsdienst, een soort fetischisme, 
wordt beheercht door menschelijke gevoelsuitingen als vrees, blijdschap, voldoening, hoop, enz. In hun oog is de natuur bevolkt door goede en kwade geesten, die zich ophouden in het water, in de lucht, in het bosch, enz. Aan het geloof aan geesten is een geheele reeks van gebruiken verbonden.

Alle voorwerpen worden door den Mentaweier geacht een ziel te bezitten. Met de ziel der voorwerpen uit zijne onmiddellijke omgeving en van zijn dagelijksch gebruik is hij dermate vertrouwd geraakt, dat hij ze niet van de hand zal doen. Zijn halsketting, zijn wapens, zijn draagmand, zijn boot, zal hij nooit weggeven of verkoopen, zelfs niet tegen hoogen prijs. Dat zou takeikei zijn, welk begrip wij het best kunnen omschrijven door: "verboden op straffe van onheil.»

Bij het verzamelen van ethnografica stuitte ik telkens op het onoverkomelijke takeikei. Vijftig gulden bood ik eens voor een halsketting, honderd gulden voor een afgodsbeeldje (natuurlijk niet in ernst), enz. enz., doch niets was te koop. Wel werd bereidwillig voor mij nieuw vervaardigd, alles waarom ik vroeg: wapens, halssieraden, houten beeldjes, e. d. g. Met een geldelijke belooning of een tegengeschenk van kleeren of een hoed was men ruim tevreden. Toch heb ik eens een pijlkoker gekocht, die reeds tot gebruik gediend had ${ }^{1}$, getuige de in het deksel geborgen talismans, bestaande uit een omwonden lapje goed en gedroogde kruiden. Vermoedelijk is de verkooper daar niet eerlijk aan gekomen.

De booze geesten, samitoe's genaamd, zijn vooral gevreesd, omdat zij ziekten kunnen aanbrengen. Slechts de priester kan de geesten zien; verschijnt een geest aan den gewonen mensch, dan is voor dezen zware ziekte of de dood er het gevolg van.

Ziekten worden veroorzaakt door de sanitoe's. Echter kunnen ook heksen ziekten teweegbrengen.

Hier volge een enkele aanteekening over heksen. Wanneer iemand - man of vrouw - verdacht wordt een heks te zijn, dan is het leven voor hem verder ondragelijk, althans in zijn stamkampong. Vroeger maakte men met heksen korte metten, ze werden eenvoudig omgebracht. Tegenwoordig, onder de geregelde bestuurstoestanden, komt zulks natuurlijk niet meer voor. Staat iemand als heks te boek, dan worden alle onheilen,

1 Thans in de collectie van het Koloniaal Instituut te Amsterdam. 
alle ziekten, aan hem toegeschreven. Zelfs sterfte onder varkens en kippen heeft hij op zijn rekening. Dan wordt al het mogelijke beproefd, om zoo iemand uit de kampong verwijderd te krijgen. Twee malen werd bij mij een klacht ingediend tegen een z. g. heks. Een deputatie uit de kampong kwam den man beschuldigen van ruzie maken of wel kortweg van tooverij. Daarbij werd het dringend verzoek gedaan, hem te doen verbannen, liefst naar Siberoet of naar Padang, in elk geval naar een andere kampong. Een onderzoek bracht aan het licht, dat in beide gevallen de beschuldigde een vermogend mensch was, d. w. z. bezitter was van een groote ladang, van vele varkens en een groot aantal klapper- en vruchtboomen. Het doel van de beschuldiging was natuurlijk, den heks verwijderd te krijgen en zich dan te verrijken met zijn onroerend goed, Het snoode plan gaat in den regel uit van den rimata, wiens woord orakel is.

De berechting dezer zaken was vrij eenvoudig. De aanklagers werden naar huis gezonden, en de kepala kampong werd opgeroepen, die mij borg moest staan dat den z. g. heks geen haar gekrenkt zou worden. Verder werden de aanklagers bedreigd met straf, indien zij wederom lichtvaardig een klacht inbrachten, en werd den rimata opgedragen, zijn invloed aan te wenden, om de betichting van tooverij van den z.g. heks bij diens kamponggenooten teniet te doen. Hiermede was de kwestie opgelost, "heksen» ondervonden geen overlast meer.

Elke Mentaweische kampong heeft hare fetischteekens. Langs den oever van de rivier, die toegang tot de kampong geeft, en ter zijde van het voetpad naar de kampong ziet men een of meer lange bamboestengels in den grond geplant, ontdaan van takken en blaren, doch niet van de bovenste pluim. Aan den voet van zoo'n bamboestengel, ertegen aan geplaatst, bevinden zich dikwijls nog andere takken, palmblaren, enz. Op deze plaatsen worden de geesten geacht neer te strijken.

Het is m. i. de plicht van elk besturend ambtenaar, de godsdienstige gevoelens van andersdenkenden niet te kwetsen, hoezeer hem het heidendom ook tegen de borst moge stuiten. Nu komt het een enkele maal voor, dat die fetischteekens moeten verdwijnen in het belang van uittevoeren werken. Het opruimen van die teekens moet natuurlijk de bevolking ergeren, zou haar zelfs tot verzet kunnen prikkelen. Doch een weinig stuurmans- 
kunst helpt wel over dit bezwaar heen. In Talapoelei (ZuidPageh) stond zoo'n fetischteeken aan den kant van het smalle voetpad, dat precies langs den rivieroever naar de kampong leidde. Dat pad moest verbreed worden en tevens verlegd, omdat de rivieroever afkalfde. Er was geen ontkomen aan: het nieuwe pad moest loopen over de plaats, waar het teeken stond. Vruchteloos trachtte ik de bevolking te overreden, het ding te verwijderen. Op mijn vraag, wat hun bezwaar was, kreeg ik ten antwoord, dat degenen, die zich aan het opruimen zouden zetten, onherroepelijk binnen één dag tijds moesten sterven. Toen ik zeide, het werk dan door dwangarbeiders te zullen laten verrichten, droeg dit de algemeene goedkeuring weg, maar .... als de dwangarbeiders tengevolge van die daad door de sanitoe's gedood werden, was het mijn schuld! Zoo gezegd, zoo gedaan; de dwangarbeiders ruimden het teeken op, en .... mochten zich bij hunne tehuiskomst, verscheidene dagen later, in een blakende gezondheid verheugen!

Een dergelijk geval deed zich voor in Taikako (Noord-Pageh). Daar moest een nieuwe brug over de rivier geslagen worden. De plaats van een der bruggehoofden was zoodanig, dat een nieuw weggedeelte noodig was, dat ook weer over een fetischteeken zou loopen. Ik droeg de oemah-hoofden op, het teeken een tiental meters te verplaatsen; de geesten zouden daartegen geen bezwaar hebben. Zonder aarzeling werd hieraan voldaan.

Ook in de woningen en in de oemah sabeoe vindt men van die fetischteekens, bestaande uit gedroogde takjes en blaren. Door met die dingen te waaieren, worden de booze geesten verdreven.

Zooals reeds eerder aangestipt is, worden talismans gedragen, op het lichaam en in bamboekokers. Meestal bestaat zoo'n talisman uit een stukje hout of een dotje gedroogde blaren, gewikkeld in een lapje, dan wel omgeven door pek; het geheel is omwonden met dunne, roode bindrottan. Deze voorwerpen hebben al geen andere strekking, dan ze in het algemeen over de geheele wereld hebben: het afwenden van onheilen en het aanbrengen van geluk.

De Mentaweier kent eigenlijk twee vrij streng gescheiden orden van geesten, n.l. die, waarmede meer in 't bijzonder de priesters bemoeienis hebben, waaraan slechts bij algemeene feesten en plechtigheden geofferd wordt; en die, welke recht- 
DE GROEP N. EN Z.-PAGEH VAN DE MENTAWEI-EILANDEN. 173

streeks zijn particulier leven betreffen. Gemakshalve zullen we die beide orden van geesten aanduiden als algemeene en bijzondere geesten.

Bij de algemeene geesten kent men slechts één goeden geest, genaamd saboeloengan, met wiens hulp de priesters ziekten bezweren, en die hen leidt hij hunne riten.

Daarentegen zijn er verschillende booze algemeene geesten, die ziekten en onheilen veroorzaken. $\mathrm{Zij}$ worden door zoenoffers gunstig gestemd. Deze zijn:

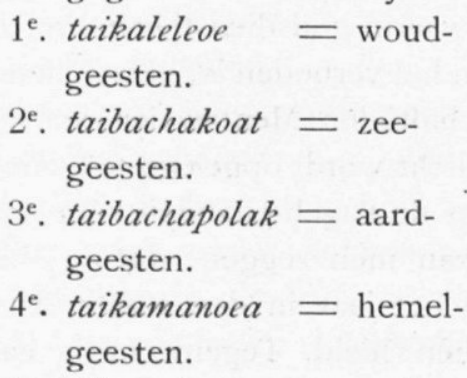

De bijzondere geesten dragen geen naam. Men kent hierbij ook slechts één goeden geest, n.l. den huisgeest. De kwade geesten zijn de geesten van de afgestorvenen; deze komen meermalen in de kampongs terug, en kloppen 's nachts aan de huizen.

De rimata, het geestelijke hoofd van de oemah, bezorgt de algemeene ritueele diensten, terwijl elk mannelijk gezinshoofd zijn eigen huispriester is.

Afgodsbeelden in den zin van aangebeden voorwerpen, vindt men bij den Mentaweier niet. Wel treft men sporadisch in een oemah sabeoe houten beeldjes

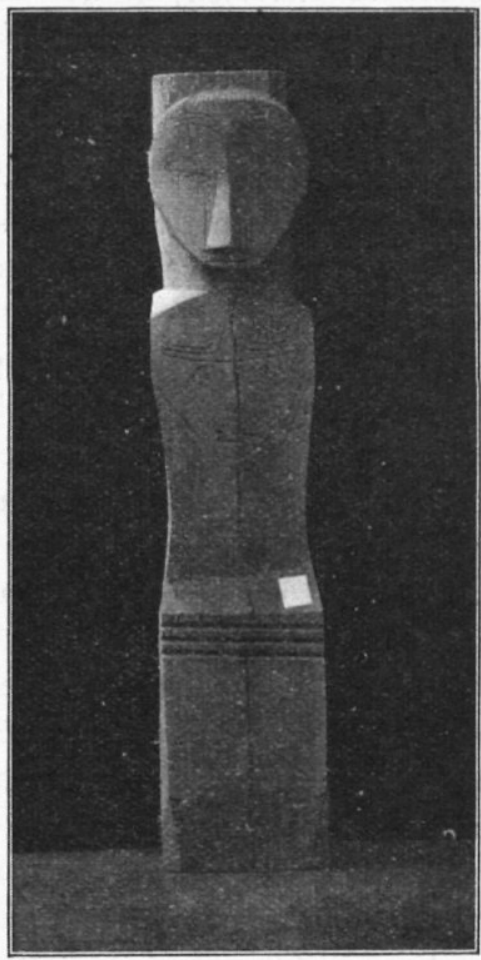

Getrouwe nabootsing ran een figuur, in hout-relief gesneden in een houten stijl aan den ingang van de oemah sabeoe te Boelak Monga (Noord-Pageh). io ware grootte.

(Coll. Koloniaal Instituut). aan, die te beschouwen zijn als animistische voorstellingen, en tot taak hebben het gebouw te bewaken.

Het zijn verschillende gemoedsaandoeningen, die het zieleleven van den Mentaweier beheersehen. Vooral angst speelt hierbij een groote rol. Is hij b. v. genoodzaakt, zich in het duister 
buiten de kampong te begeven, dan kan men hem doordringende, zangerige geluiden hooren uitstooten, geluiden hem door angst ingegeven en die ten doel hebben de booze geesten op de vlucht te jagen.

Pantang en poenèn. Pantang en poenèn staan met elkaar in nauwe betrekking: Poenèn is een offerfeest met de daaraan verbonden gebruiken en verbodsbepalingen. $\mathrm{Bij}$ poenèn verklaart de Mentaweier zich, of wel de kampong "pantang", waaronder men heeft te verstaan een staat, waarin godsdienstige gebruiken op den voorgrond staan, en waarin het verboden is, verschillende dingen te doen. Dit laatste verschaft den Mentaweier veel genoegen, omdat hem daarmee de plicht wordt opgelegd te luieren.

Beschouwt men den toestand op de Pageh-eilanden vóór onze intensieve bestuursvestiging, dan kan men zeggen, dat de Mentaweier ongeveer 10 maanden van het jaar in den toestand van pantang verkeerde, $\mathrm{m}$. a. w. poenèn hield. Tegenwoordig gaat dat niet meer en zorgt ons bestuur er wel voor, dat hij zijn tijd nuttiger besteedt. Voor eenigszins langdurige poenèn wordt de toestemming van de overheid vereischt, vooral ook daarom, wijl daarbij heerendiénsten verzuimd worden. Immers, de poenèn-adat laat niet toe, dat de Mentaweier dergelijke werkzaamheden verricht.

Groot is het aantal gevallen, waarin de Mentaweier poenèn viert. Al die gevallen te noemen is niet doenlijk, omdat er niet te voorziene omstandigheden zijn, waarin personen of kampongs pantang verklaard worden. Heeft er iets buitengewoons plaats, iets onaangenaams, waaruit men besluit dat de geesten gebelgd zijn, dan moet poenèn dienst doen als panacée daartegen. Zoo werd in een kampong een vrouw door een krokodil gebeten, reden om poenèn- te houden, want de kampong moest gezuiverd worden van kwade geesten.

Gedurende het pantang zijn van een kampong mogen geen vreemden daar binnenkomen. Onder vreemden hierbij ook te verstaan menschen van andere kampongs. Mocht een vreemde zich in een kampong bevinden, wanneer deze pantang verklaard wordt, dan is het hem niet geoorloofd, de kampong te verlaten vóór den afloop der poenèn.

Een kampong, die pantang is, herkent men doordat aan of op de toegangswegen pantangteekens geplaatst zijn, die over- 
eenkomen met de reeds beschreven fetischteekens (bamboestengels). Deze pantangteekens roepen den vreemde het rechtsomkeert toe. Toch zal het den Mentaweier niet in zijn gevoelens kwetsen, wanneer onze ambtenaren en troepen die teekens niet eerbiedigen.

Men heeft te onderscheiden kampongpoenèn en familie- of persoonlijke poenèn, al naar gelang de oorzaak tot het feest van algemeenen of persoonlijken aard is.

Alle poenèn ontleenen haar oorsprong aan vrees en bedruktheid; de Mentaweier voelt zich n.l. machteloos tegenover zware ziekten en onheilen.

Kampongpoenèn wordt gehouden o. a. na een sterfgeval; vóór en na het gemeenschappelijk aanleggen van een ladang; bij epidemiën of het heerschen van ziekten; bij abnormaal groote sterfte, hetzij onder volwassenen of kinderen; wanneer er een klapperboom in de kampong omvalt; na afloop van den bouw eener oemah sabeoe, of herstelling daaraan; wanneer de bevolking wordt opgeroepen voor bruggenbouw of om een weg door de kampong aan te leggen of wel een pagger (heg) om de kampong te plaatsen. Ook na een geslaagde jacht op apen, herten of schildpadden.

Niemand mag zich aan deze kampongpoenèn onttrekken. Bij poenèn wordt aan de geesten geofferd en verder veel geluierd. Voor de ritueele diensten zorgt de rimata, behalve wanneer ziekte de reden tot poenèn is, in welk geval de priester eraan te pas komt.

Familie- of persoonlijke poenèn worden o. a. gehouden bij ziekten in het huisgezin; bij het aanleggen van een ladang; bij het maken van een boot e. d. g. Het gezinshoofd brengt in zijn kwaliteit van huispriester hierbij het offer, echter weer met deze uitzondering, dat de priester geroepen wordt bij poenèn tot verdrijving van ziekte.

Zijn er bij een gezamenlijke jacht apen of herten neergelegd, dan wordt de buit naar de oemah sabeoe gebracht en daar door den rimata verdeeld. Ieder hoofd van een huisgezin krijgt een stukje. Dat dit soms, wanneer de jacht weinig heeft opgeleverd, een bescheiden deel is, laat zich begrijpen. De verdeeling van het vleesch gaat gepaard met de noodige riten; gongs en bedoeks (inlandsche trommen) worden daarbij geslagen. Geweien, schedels, beenderen en ingewanden worden den geesten gewijd, 
en in de oemah opgehangen. De gedachte, die hierbij voorzit is, dat de dieren des wouds ook den woudgeesten toebehooren; zouden nu de Mentaweiers die dieren voor voedsel gebruiken, zonder aan de geesten te offeren, dan zou hen voorzeker onheil treffen.

Als uitvloeisel van poenèn kent de Mentaweier een menigte gebruiken en verbodsbepalingen, die later bij de bespreking van huwelijk, geboorte en sterfgevallen nader in het bijzonder vermeld zullen worden.

Verbodsbepalingen. De verbodsbepalingen bij persoonlijk poenèn zijn voor ieder bijzonder geval meestal weer verschillend. De verbodsbepalingen zijn zóó talrijk, dat men er een boekdeel mede zou kunnen vullen; daarom volgen hier slechts die, welke in het dagelijksch leven van den Mentaweier het meest op den voorgrond treden en die hem het meest belemmeren in zijn arbeid.

De gehuwde man mag geen zwaar werk verrichten, geen boomen vellen, geen ladang aanleggen en niets planten; alleen mag hij de ladang onderhouden. Voor dergelijk zwaar werk (behalve boomen vellen) is dan ook de gehuwde vrouw aangewezen. $Z_{i j}$ heet in het Mentaweisch tainalalep; lalep beteekent huis, tainalalep is dus: degene van het huis, m. a. w. degene op wie alle bezigheden drukken.

Verder mag de gehuwde man geen ongeheiligd vleesch eten (zie bij poenèn), geen huis bouwen, geen dak indekken, geen dier dooden of slachten, enz. ${ }^{1}$ Voor den jongeling en voor de kinderen bestaan deze verbodsbepalingen niet; behalve bij poenèn mogen zij alles doen en alles eten. Daarom blijven de jongelingen liefst zoo lang mogëlijk ongehuwd en leven dan in wilden echt, tot zij reeds vrij groote kinderen hebben, die desnoods het voor de gehuwde mannen verboden werk kunnen verrichten.

Voor de vrouwen bestaan slechts, weinig verbodsbepalingen,

1 Alle verbodsbepalingen spruiten voort uit vrees voor straf van de zijde der geesten. De grootste angst van den Mentaweier is, dat die straf zal bestaan uit ziekte zijner kinderen. Hij denkt ook, dat die straf hem zal treffen, als hij ongeheiligd vleesch eet. Het is zeer zeker geen benijdbare toestand, alleen vleesch te mogen eten bij poenèn.

Maar .... il y a des accomodements; als de Mentaweier oud van dagen is, en hij heeft geen vooruitzicht meer om kinderen te krijgen, dan is het vleesch eten hem geoorloofd. 
en zeer zeker niet op het gebied van arbeiden; zij zijn de "werkbijen» op wie de grootste zorg voor het levensonderhoud rust.

Mag er bij de verbodsbepalingen voor den gehuwden man nog een kern van gegrondheid zijn, omdat hij als hulppriester zelf de gewone offers moet brengen, en zich daarbij moet hoeden voor kwade invloeden, voor het grootste gedeelte zijn die bepalingen een voorwendsel tot luiheid.

In sterkere mate als de gehuwde man als huispriester gehouden is, sommige dingen na te laten, is de rimata gebonden aan verbodsbepalingen. Deze mag zoo goed als in 't geheel geen arbeid verrichten. Nu en dan mag hij gaan visschen, klappers plukken of voedsel van het veld halen, maar ook niet veel meer.

Zedelijkheid. Met de zedelijkheid bij de Mentaweiers is het al zeer droef gesteld. Wel kennen zij de instelling van het huwelijk, doch hetgeen vóór en zelfs in den huwelijken staat gebeurt, zou menig dier des velds een doorn in het oog zijn. Bij de vermelding van het huwelijk zullen van zelf eenige dier ergerlijke toestanden ter sprake komen.

De Mentaweische vrouw doet zich niettemin tegenover den vreemdeling eer schuw en bedeesd, dan toeschietelijk voor. Ook is het bij de Mentaweiers strijdig met het fatsoen, om in het bijzijn van vrouwen onvertogen woorden te gebruiken of over onkiesche onderwerpen te spreken. Liever dan zulke taal aan te hooren, verwijdert de Mentaweische vrouw zich.

Afgestorvenen. Ook de Mentaweier erkent de onsterfelijkheid van de ziel. Het hiernamaals wordt door hem sabeoe laggai genoemd, hetgeen beteekent: de groote kampong:

Wanneer er iemand sterft, dan tracht zijn geest ongeveer drie dagen lang in het sterfhuis terug te komen, van welk bezoek de overlevenden allerminst gediend zijn.

Bij elk sterfgeval vermeent de Mentaweier dat de kampong verontreinigd is, en moeten de kwaden invloeden door poenèn geweerd worden.

Weliswaar kennen de bloedverwanten en vrienden van den overledene oprechte smart, doch die is spoedig voorbij en dan begint de ceremonieele rouw, die in 't bijzonder tot uiting komt Dl. 70 . 
in een vervaarlijk gehuil, langzamerhand overgaande in een zeker klaaggezang. Nadert de tijd van de begrafenis, dan wordt het lijk in lijnwaad gewikkeld, dat door vreemde handelaren in groote hoeveelheid als ruilartikel wordt ingevoerd. De Mentaweiers hebben, speciaal voor begrafenisdoeleinden, altijd een ruimen voorraad daarvan in huis; 10 tot 15 blok stof worden meermalen voor de inwikkeling van een lijk gebruikt. Buitendien krijgt de overledene een ruime hoeveelheid kralen mede, opdat zijn ziel zich in het hiernamaals daarmede zal kunnen tooien.

Aangezien het den gehuwden mannen verboden is, een begraafplaats te betreden, wordt de geheele begrafenis bezorgd door jongelingen. Deze dragen het lijk, nadat het op bovenomschreven wijze afgelegd is, één of twee malen het huis rond, voordat zij het naar buiten brengen, of wel zij dragen het eventueel door de achteropening het huis uit. De ziel van den overledene toch is een booze geest, en moet op deze wijze misleid worden, opdat hij het sterfhuis niet terugvindt. Gelukt dit hem desondanks toch, dan worden de bewoners 's nachts door kloppen en rammelen aan de deur verontrust. Door offers en waaieren met gedroogde blaren (fetischteekens) moet de geest dan verdreven worden, anders haalt hij zich een metgezel, m. a. w. komt een der bewoners eveneens te overlijden. In het bijzonder zijn het de geesten van plotseling gestorven jonge menschen en van hen, die zelfmoord pleegden door ophanging, welke op deze wijze de overlevenden verontrusten.

Voor het vervoer van het lijk gebruikt men een soort draagbaar, vervaardigd van reepen gespleten bamboe (kree). Het lijk,

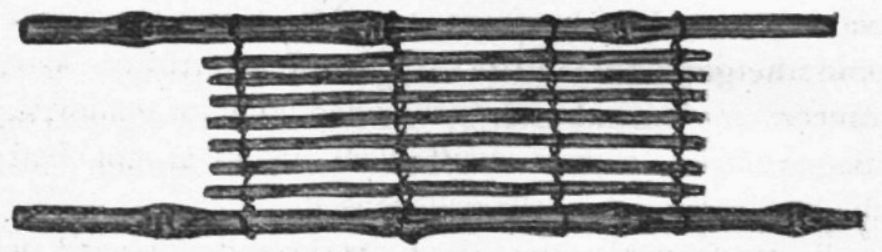

Draagbaar (kree).

buiten gebracht zijnde, wordt in een prauw gelegd, en naar de begraafplaats vervoerd.

Bij de Mentaweiers bestaat van ouds de exhumatie van lijken, d. w. z. deze worden boven den grond neergelegd, op takken, 
ongeveer 1 M. hoog. Dikwijls ligt de begraafplaats dicht bij het zeestrand, of nabij de monding eener rivier en zoodoende komt het wel voor, dat de lijken door krokodillen worder, weggehaald. Door deze omstandigheid zijn enkele kampongs ertoe overgegaan, hunne dooden te begraven in ongeveer $1 \mathrm{M}$. diepe kuilen. Ook komt het een enkele maal voor, dat de lijken eenvoudig op den grond gelegd worden.

Een Mentaweische begraafplaats is geen omheind stuk terrein, waar de dooden op regelmatige wijze worden geëxhumeerd of begraven, en dat behoorlijk wordt onderhouden. Het is eenvoudig een wel begroeid plekje grond, welks ligging voor den oningewijde moeilijk te ontdekken is.

Wanneer de jongelingen de begraafplaats verlaten; gaan zij langs een omweg naar de kampong terug, hetgeen ten doel heeft, den geest van den afgestorvene te misleiden omtrent den weg naar de kampong. Zoowel bij het gaan naar de begraafplaats als bij het terugkeeren daarvan is het streng verboden, omtezien.

$\mathrm{Na}$ de begrafenis heeft natuurlijk weer poenèn plaats; de geheele kampong wordt daarbij door de jongelingen afgewaaierd middels takken met droge blaren, waardoor de verontreiniging wegens het sterfgeval opgeheven is.

Het gezin en de verdere nabestaanden van den overledene leggen als teeken van rouw gedurende 2 à 3 maanden hunne kralenversiering af, en gedurende ongeveer een jaar allen overigen tooi.

Een bijzonder gebruik bij sterfgevallen is het afleggen van den naam. Niet bij wijze van rouw, doch uit vrees dat de geest van den afgestorvene zich dien naam zal herinneren.

Deze naamaflegging heeft gedurende ongeveer een jaar plaats door ouders, die hun kind door den dood verloren hebben.

Bij het overlijden van een gehuwden man of gehuwde vrouw, legt de overlevende wederhelft den naam af tot een nieuw huwelijk, of tot het einde des levens.

Ook heeft naamaflegging door overlevenden plaats, wanneer van twee of meer personen van denzelfden naam er een komt te overlijden.

Het spreekt van zelf, dat naamaflegging niet in zich sluit naamloos blijven; de betrokken persoon neemt een anderen naam aan. 
Sterft een vrouw in - de kraam, dan mag, volgens oud gebruik het kind niet blijven leven; het wordt gedood en met de moeder bijgezet. Sterft echter de moeder kort na de bevalling, door een andere oorzaak dan kraamvrouwenziekte, dan mag het wicht in het leven blijven, en wordt ter verzorging gegeven aan een andere moeder. Onnoodig haast te vermelden, dat het barbaarsche gebruik van pasgeboren kinderen dooden tot het verledene behoort, nu ons bestuur overal zijn invloed doet gelden.

Opvatting van natuur en van natuurkrachten. In de natuuropvattingen van den Mentaweier neemt men antropopatisme waar. Hemellichamen denkt hij zich behept met menscielijke eigenschappen. Het uitspansel denkt hij zich op kinderlijke wijze als een groote tent; wanneer men slechts lang genoeg in eenzelfde richting vaart, moet men ten slotte het uitspansel kunnen bereiken en betastcn. De zon klimt op een voor menschenoogen onzichtbaren berg, welks top zij midden op den dag bereikt; daarna daalt zij aan de andere zijde, om des avonds in zee te vallen. Zonsondergang noemt men in het Mentaweisch dan ook kabilèkan soeloe, d. w. z. het vallen van de zon.

Zon en maan zijn twee hemellichamen, die strijd met elkaar gevoerd hebben. De maan heeft hare kinderen, n.l. de sterren. Even goed heeft de zon vroeger kinderen gehad. Zon en maan badden echter afgesproken, ieder hare eigen kinderen op te eten. De zon hield zich aan de afspraak, doch de maan verborg hare kinderen, in plaats van ze op te eten. Des avonds, toen de zon verdwenen was, haalde de maan hare kinderen weer te voorschijn. De zon ontdekte het bedrog, en beoorloogde van toen af de maan. Bij dien strijd gelukt het de zon wel eens, een stuk van de maan af te slaan (maanstanden).

Geneeskunde. Bij eenigszins ernstige ziekten, wanneer gewone huismiddeltjes falen, wordt de sikerre (priester) te hulp geroepen. Deze is medicijnmeester en duivelsbanner. $\mathrm{Hij}$ is natuurlijk een gewichtig personage; sommigen hunner staan als zeer bekwaam te boek en genieten dikwijls de eer, naar verafgelegen kampongs te worden ontboden, om daar hunne krachten te beproeven op ernstige patiënten. Voor zijne diensten laat de sikerre zich betalen, in dien zin echter, dat hij niets eischt doch gaarne aanneemt wat men hem schenkt. Meestal wordt 
hem in ruil voor zijne diensten een geschenk vereerd, als varkens, kippen, versierselen, enz. Bij minvermogenden verleent hij daarentegen zijn hulp gaarne om niet.

Den sikerre herkent men uiterlijk aan zijne bijzondere versierselen, die talrijk en excentriek zijn; o.a. draagt hij veel koperen armringen en heeft hij meestal een spiegeltje aan halsketting of heupband hangen.

Niettegenstaande de groote (werkelijke of vermeende) bekwaamheden van den sikerre, stelt de Mentaweier vrijwel onbeperkt vertrouwen in de geneeskunde der Europeanen. Zelfs kwam het voor, dat Mentaweische vrouwen ter hoofdplaats Sawang Toengkoe verschenen, om in de ziekenzaal van het detachement geneeskundige behandeling te zoeken. Met vertrouwen wenden zieken en gewonden, zelfs uit verafgelegen kampongs, zich tot de zendelingen, die op hun station een klein hospitaal hebben. De bevolking is in dit opzicht veel verplicht aan de zendelingen, die de zieken belangeloos en liefderijk verplegen in hun hospitaaltje. De verpleegden zijn alleen verplicht voor eigen voeding te zorgen, een wijze maatregel, getroffen om simulanten te weren. Niets doen, gratis een onderdak, eten en drinken, 't zou voor een Mentaweier zijn om te watertanden!

Wanneer militaire patrouilles of zendelingen de kampongs bezoeken, maakt de bevolking ook gretig gebruik van de gelegen heid, om medicijnen te vragen of verbanden te doen aanleggen.

Volkskarakter en volkseigenschappen. Over het weinig krijgszuchtig karakter van de Mentaweiers is reeds eerder gesproken (zie onder "wijze van oorlogvoeren»). Wel bestaat bij hen van ouds de bloedwraak, doch die werd voornamelijk in eere gehouden door de lieden van Siberoet.

Luiheid is een van de grootste volksondeugden. Eeuwenlange indolentie heeft het volk op lagen trap van ontwikkeling gehouden. Ware het volk meer vooruitstrevend en ondernemend geweest, dan zouden althans enkelen hunner zich vaker buiten hun gebied begeven hebben, hetzij op ontdekkingstochten, hetzij om redenen van handel. Dan zouden de Mentaweiers rijst- en tabaksbouw, veeteelt e. d. g. van hunne Oostelijke naburen hebben geleerd. Dan zouden zich handwerkslieden onder hen hebben ontwikkeld, en hadden zij steen- en metaalbewerking gekend. 
$\mathrm{Nu}$ niets van dat al. Consumptie-artikelen en gebruiksvoorwerpen, die de Mentaweier best zelve zou kunnen produceeren, worden ingevoerd. Zelfs de meest primitieve volken hebben hunne bijlen en andere voorwerpen van steen. De Mentaweier heeft zelfs die niet. Wat hij noodig had, werd ingevoerd, waartoe zou hij zelf de handen uit de mouwen steken?

Zijn zucht tot nietsdoen en zijn ritueele voorschriften pasten merkwaardig goed bij elkaar. Het niet te vermijden zware werk werd door de vrouw verricht. De Mentaweier bleef dus wat hij was: lui en onontwikkeld.

Gelukkig begint hierin langzaam verandering te komen. Ons bestuur doet wat in zijn vermogen is, om den Mentaweier tot arbeid te brengen. De kamponghoofden worden nu en dan in de gelegenheid gesteld, Padang te bezoeken, om te zien, wat daar de beschaving biedt. Veel succès is van onze pogingen in de naaste toekomst niet te verwachten: wat eeuwen misdeden, is niet in enkele jaren goed te maken.

Toch is er van den Mentaweier wel iets te maken. Hij is gewillig en niet onhandig. Met behoorlijke leiding is hem veel bij te brengen. Hier zij nogmaals gewezen op de kampong Salaoinam, aan welker hoofd een voortvarende kepala kampong staat, die de bevolking leidt en leert. Wanneer deze aan zijne onderhoorigen een taak stelt, dan wordt daaraan vlot en ijverig gewerkt, en hetgeen gepresteerd wordt, is - gegeven de geringe hulpmiddelen - uitstekend te noemen.

Aan gewilligheid paart de Mentaweier gedweeheid. Het is b. v. zelden noodig, delinquenten te doen arresteeren; na oproeping verschijnen ze gereedelijk ter hoofdplaats, ook al weten ze, dat hun straf te wachten staat. Hoezeer de Mentaweier een afschuw heeft van werken, tegen zijn heerendienstplichten zal hij zich niet verzetten, omdat hij weet dat ze billijk zijn en ook al, omdat hij zich onder contrỏle weet en hij bij nalatigheid strafschuldig is. Over het algemeen kan hem geen plichtsbesef worden toegekend; zonder contrôle zal hij weinig uitvoeren.

De Mentaweier is verdraagzaam, het moeten - in zijn oog zeer gewichtige redenen zijn, die hem tot verzet prikkelen.

Het volk is over het algemeen hebzuchtig en weinig vrijgevig. Dit laatste geldt meer tegenover vreemdelingen en is voor een groot deel een uitvloeisel van takeikei (zie bl. 170). Onder 
elkander zijn de Mentaweiers gul en gastvrij. Gebrek lijden is voor hen vrijwel uitgesloten; wie - om welke reden dan ook niet te eten mocht hebben, vraagt en krijgt voedsel van anderen. En, waar handen te kort komen, helpt men elkander gaarne bij den arbeid.

Men kan den Mentaweier eerlijk en geloofwaardig noemen. Diefstal komt weinig voor. Wat hij - gevraagd of ongevraagd mededeelt, komt meestal met de waarheid overeen. Oprecht is hij ook. Eens trof ik een Mentaweier in het bosch op jacht aan; daar hij zonder vergunning wapens droeg, verklaarde ik hem strafschuldig en nam hem als arrestant mede. De man zei toen dat hij met een makker uit jagen was, en bood zich aan dien uit het bosch te halen. Tegenover ieder ander zou het dom zijn, op zoo'n aanbod in te gaan, omdat men wel begrijpen kan, dat de man zich uit de voeten zou maken. Doch omdat het een Mentaweier was, nam ik het aanbod aan, en de man kwam na eenigen tijd met zijn jachtgezel terug, die eveneens arrestant werd. Toen deelden zij beiden mede, dat nog een twintigtal andere mannen uit hun kampong eveneens zonder toestemming uit jagen waren gegaan. $\mathrm{Zij}$ deelden de juiste namen van de overtreders mede, die, later opgeroepen zijnde, grifweg bekenden en niet de minste rancune toonden tegenover de beiden, die hen verraden hadden.

De Mentaweier is dom en gemakkelijk bij den neus te nemen, hetgeen dan ook dikwijls geschiedt door Maleiers en Chineezen, die hen overvragen bij den ruilhandel. Doch in dit opzicht houdt ons bestuur een oog in het zeil en tracht afzetterij en knevelarij te voorkomen.

Wie met den Mentaweier in gesprek raakt, wordt spoedig getroffen door diens breedsprakigheid. Veel woorden heeft hij noodig, om weinig uit te drukken; omgekeerd echter zijn ook vele woorden noodig, om den bekrompen Mentaweier iets aan het verstand te brengen. Met zijne verstandelijke ontwikkeling is het niet te best gesteld; het liefst laat hij zich alles aanschouwelijk maken. Moet hij b.v. eenige getallen onthouden, dan raapt hij overeenkomstige getallen steentjes op, en bewaart die afzonderlijk. Afmetingen onthoudt hij door de overeenkomstige lengte of dikte van eigen lichaamsdeelen; b.v. een boomstam van één dijdikte en van drie vaam plus één onderarmslengte. De vaam (depa), zijnde de afstand tusschen de vingertoppen 
der beide handen, wanneer de armen zijwaarts zijn gespreid, is de eenig gangbare maat bij de Mentaweiers. Van andere maten en gewichten hebben ze geen verstand.

De Mentaweische vrouw is over het algemeen schuw tegenover den vreemdeling. $Z \mathrm{ijn}$ zij zonder mannelijk gezelschap, dan slaan zij meestal bij het zien van Europeanen of Inlandsche soldaten op de vlucht. Men moet die schuwheid wel op rekening stellen van hare vrees voor gewelddaden. Toch is daar geen gevaar voor. Uiterlijk en voorkomen van de Mentaweische vrouw zijn zoodanig, dat.... (het zij euphemistisch gezegd) zij slechts een Mentaweischen man kan bekoren!

Sagen en overleveringen. Het Mentaweische volk kent verscheidene verhalen uit vroeger tijd. Wanneer men ze alle kende, zou men wellicht eenigszins kunnen doordringen in de vroegere geschiedenis van het volk. Het is echter moeilijk, den Mentaweier aan het vertellen te krijgen. Vraagt men hem naar verhalen, naar oudheden of naar ethnografica, dan staat hij dadelijk met zijn antwoord klaar: ta-n-ai, d.w.z. "is er niet». Men vraagt zich dan onwillekeurig af: zouden soortgelijke mededeelingen misschien takeikei zijn?

Van het kleine aantal mij bekende verhalen zijn reeds eenige vermeld. Hier volgt een legende, die bij de Mentaweiers in verschillende lezingen bekend is, doch genormaliseerd als volgt luidt:

\section{Het hert en de krokodil.}

Er waren eens twee Mentaweiers, een man en een vrouw. Ze waren niet gehuwd, maar hadden twee kinderen, een jongen en een meisje, waarvan laatstgenoemde het oudste was.

Op zekeren dag keerde de man van de vischvangst huiswaarts, en gaf de gevangen visch aan de vrouw, ter bereiding van het middagmaaI. Hij deed de visch daartoe in een bamboe; onderwijl vulde de vrouw een andere bamboe met pisang. Alvorens deze bamboe op het vuur te zetten, verwijderde zij zich even uit het huis. Van die gelegenheid makkte het zoontje gebruik, om den inhoud van de bamboes ongezien te verwisselen; in de visch-bamboe deed hij slangen en ander ongedierte, de pisangbamboe vulde hij met pisangschillen. De niets vermoedende vrouw zette de bamboes op het vuur en kookte den inhoud gaar. 
Toen men wilde gaan eten, en de bamboes geopend werden, ontstond er een hevige ruzie tusschen man en vrouw. De man verweet de vrouw, dat zij hem pisangschillen wilde laten eten, en de vrouw verweet den man, dat hij haar slangen gegeven had in plaats van visch. Ieder van hen voelde zich natuurlijk onschuldig aan het bedrog, waardoor de toorn ten top steeg en zij elkander wraak zwoeren.

(Eerst veel later in dit verhaal duikt de man weer op, zoodat men moet aannemen, dat hij zich uit de voeten gemaakt heeft).

Eenigen tijd na het voorgevallene ging de vrouw met hare zuster naar de rivier om met het schuifnet ' te visschen. $\mathrm{Na}$ de vangst besloten beide huiswaarts te gaan. De vrouw (van den man) sprak tot hare zuster: "hier, neem de visschen mede voor mijne kinderen, ik moet nog even naar het veld». De zuster ging naar huis met de visschen, doch de moeder liet op zich wachten. Daarop ging eerstgenoemde terug naar de rivier en trof daar hare zuster aan, die bezig was het vischnet met de stokken te verzwelgen. Vol ontzetting riep ze uit: "wat doet ge toch?», waarop de moeder antwoordde: « ja, dat ligt in mijn aard; nu komt mijn wraak; ik keer niet meer terug in de kampong, en de stelen van het net zullen als horens weer te voorschijn komen».

(Ofschoon het verhaal zulks niet vermeldt, verdwijnt nu blijkbaar de vrouw.)

Den volgenden dag gingen de kinderen op zoek naar de moeder, waarbij het meisje haar broertje op den rug droeg. In het bosch gekomen, riep het meisje: in a in a saraleleoe alegi sogaikoe!» (moeder, moeder, antwoord op mijn roepen). $\mathrm{Zij}$ gingen verder, het meisje aldoor haar moeder roepende. Eindelijk hoorden zij een stem, en, op dat geluid afgaande, troffen zij de moeder aan. Alle drie vleiden zich neder; de moeder gaf het knaapje de borst. De kinderen sluimerden in, en om te zien of ze vast sliepen, kneep de moeder hen. Het jongetje werd wakker

1 Dit is een vischnet, aangebracht aan twee bamboestokken, I $3 \mathrm{M}$. lang, die kruisgewijze aan elkaar bevestigd zijn, als een groote schaar. De lange armen worden in de handen gehouden, de korte armen met het net rusten op den bodem van het vischwater, waarlangs het voortgeschoven wordt. 
door dat knijpen, en vroeg: "moeder, moeder, waarom knijpt ge mij?» waarop zij antwoordde: "dat zijn de nagels van uw oom» ${ }^{1}$. $\mathrm{Na}$ een poosje kneep ze de kinderen opnieuw, die toen bleken vast ingeslapen te zijn. Hierop vluchtte de vrouw, de kinderen latende, waar ze waren.

Toen de kinderen wakker werden, en hun moeder misten, riep het meisje weer: "ina ina saraleleoe alegi sogaikoe!» Daarop kwam de moeder terug, maar in de gedaante van een hert. Vol schrik riep het meisje uit: "moeder, moeder, wat hebt ge gedaan?» waarop deze antwoordde: "ja, dat ligt in mijn aard; mijn wraak zal de kampong bereiken, waarheen ik niet meer terugkeer; gaat naar de rivier en ziet, waarheen het water stroomt, daar is de monding, en daar ligt onze kampong».

(Het hert verdwijnt blijkbaar).

De kinderen gingen naar de rivier en volgden de stroomrichting. Toevallig was het vloed en stroomde het water naar den bovenloop, waardoor zij verdwaalden en terecht kwamen in een veld, waar een man woonde, Goeloebena geheeten. Het meisje was bang, dat de man haar broertje dooden zou en verstopte het in een vuilnishoop. Goeloebena ontdekte het meisje en nam haar als bruid tot zich. Hij ging op vischvangst, en daarna vierde hij bruiloft met de jonge vrouw, d. w. z. zij hielden poenèn. Na de offeranden zaten zij samen te eten en telkens wierp toen het meisje steelsgewijze visch en ander voedsel naar de vuilnishoop, waar haar broertje verstopt was. Goeloebena bemerkte dit echter, ging naar de vuilnishoop en vond den jongen, dien hij niet doodde, maar bij zich opnam. Toen volgden nieuwe poenèn en een nieuwe maaltijd.

$\mathrm{Na}$ geruimen tijd werd Goeloebena een zoon geboren. Goeloebena's vrouw ging eens met haar broeder per prauw naar den bovenloop der rivier, en zij ontmoetten daar hun vader, dien zij niet herkenden en die ook hen niet herkende. De vader vroeg haar: "hebt gij mijne kinderen niet gezien?" waarop zij antwoordde: "neen!» Maar dadelijk daarop zeide zij het volgende spreukje op: "als het mijn

1 Wat dit beteekenen moet, is niet recht duidelijk. 
teteoe ${ }^{1}$ is, dan blijve het plankje, waarop hij in zijn boot zit, aan hem vastkleven!» En het plankje bleef vastkleven. Daarop zeide zij: "als het mijn teteoe is, dan late het plankje weder los!» Hetgeen geschiedde. Nu herkenden de kinderen hun vader, maakten zich bekend als zijn kinderen, en namen hem mede naar huis, waar de vrouw eten kookte, en zich allen gezamenlijk aan den maaltijd zetten. Toen de vader wilde drinken, riep de vrouw: "als het onze teteoe is, dan blijve de drinknap aan zijn mond hangen!» De drinknap bleef aan zijne lippen kleven. Daarna zeide zij: "als het onze teteoe is, dan late de drinknap weder los!» En de drinknap liet los. Toen zeide zij verder: "gij zijt onze vader, wij zijn Uwe kinderen, en moeder heeft zich in een hert veranderd.» "Nu, dan zal ik mij in een krokodil veranderen, » zeide de vader. Daarna nam hij de kinderen mede naar de rivier om te baden. In de rivier probeerden zij, wie het langste zou kunnen onderduiken. Eerst doken de kinderen onder, waarbij de vader telde: $1,2 \ldots$ tot 9 . Toen kwamen de kinderen proestend en ademloos boven water. Hij lachte ze uit en zeide hun te tellen, als hij zou onder duiken. De kinderen telden tot 10 , tot 20 , tot 30 , eindelijk tot 100 . Toen hoorden zij het water ruischen, en een stem daaruit zeggen: "nu ben ik een krokodil, ik ga» ${ }^{2}$.

Eenigen tijd later gingen zuster, broer en het kind van Goeloebena naar den boomgaard om vruchten te plukken. Voor het kind plukten zij zure, onrijpe vruchten en gingen in hun boot, om huiswaarts te varen. Toen verscheen de krokodil, die riep: "waarom hebt ge mijn kleinkind onrijpe vruchten gegeven?» Daarbij sloeg hij met zijn staart toornig het bootje ondersteboven. Het kleinkind klauterde op den rug van den krokodil, die het kind naar huis terugbracht.

(Hoe het broer en zuster vergaat, verneemt men niet, blijkbaar komen zij er goed af, want in het verdere verhaal treedt de broer weer op).

1 Teteoe beteekent weduwnaar of weduwe; kinderen, die hun vader of moeder verloren hebben, spreken $\operatorname{de}(n)$ overlevende(n) aan met teteoe.

" "Ik ga" is de afscheidsgroet van den Mentaweier; wij zouden zeggen: "adieu" of "gegroet". 
$\mathrm{Na}$ het gebeurde ging het kleinkind dagelijks met voedsel naar de rivier, en riep daar: "teteoe, kom, teteoe, haal uw spijs!»Dan kwam met veel lawaai de krokodil aangezwommen en sperde den muil open, waarin het jongetje het medegebrachte voedsel wierp. Op zekeren dag wilde de zoon (van den krokodil) ook eens naar de rivier gaan, om den krokodil te voeren. De kleinzoon stelde hem voor mede te gaan, en bood zich aan te toonen, hoe het voeren geschieden moest. De zoon werd boos over dat voorstel en vroeg of de andere misschien ouder was dan hij. De kleinzoon antwoordde, dat hij zijn gang dan maar moest gaan, hij moest weten wat hij deed.

Op een goeden morgen ging dan de zoon met voedsel naar de rivier, en riep den krokodil. Als gewoonlijk kwam deze weer met veel rumoer aangezwommen en sperde den muil open. Op dat gezicht ontstelde de zoon zoodanig, dat hij het voedsel liet vallen, en zich uit de voeten makte. Begrijpelijkerwijze ontstak de krokodil in woede. Hij besloot zich te wreken op de menschen, en gaf eenige voorschriften, waaraan de menschen zich streng moesten houden, wilden zij zijn toorn ontgaan.

Hier is het verhaal feitelijk uit. Volledigheidshalve volgen hier eenige verbodsbepalingen, door den krokodil gegeven; verder een verhaal hoe de jacht op herten ontstaan is, en de beschrijving van poenèn voor krokodil en hert. Dit alles hangt nauw samen met het gegeven verhaal, en men zou daarbij aan totemisme kunnen denken, ware het niet, dat de zuivere kenmerken daarvan ontbreken. '

Door den krokodil zijn o. a. de volgende verbodsbepalingen uitgevaardigd:

Bamboes, die dienst hebben gedaan als kookgerei, mogen niet in het water geworpen worden.

Klappers mogen niet in tweeën gespleten worden. Bij andere

$1 \mathrm{Bij}$ de volken, die totemisme kennen, heeft elke stam zijn totem, een dier of voorwerp, dat als oorsprong van dien stam als anderszins wordt vereerd. Wel zou men in poenèn voor krokodil en hert een zekere vereering voor die beesten kunnen zien, doch voor apen en soms voor schildpadden wordt ook poenèn gehouden. Het feit, dat het vereeren (om dit eens zoo te noemen) van krokodil en hert niet gebonden is aan een bepaalde oemah (hier als stam te beschouwen) is m. i. voldoende, om geen totemisme aantenemen. 
volken wordt de van bast en schaal ontdane klapper gespleten, en voor consumptiedoeleinden geraspt. Wil de Mentaweier een klapper raspen, dan moet hij de volle, ongebroken noot nemen. Breekt de klapper onverhoopt bij het afnemen van de schaal in tweeën, dan haast de Mentaweier zich, "bodjoi» te roepen, d. w. z. "verontschuldig mij.»

Gebeurt het, dat iemand door een krokodil wordt gebeten of verslonden, dan heet de kampong of de oemah verontreinigd. Niemand wil spreken met de leden van de oemah, waartoe het slachtoffer behoort. Daarop volgt poenèn, om de onreinheid af te schudden, iets, dat soms jarenlang duurt.

Alvorens te beschrijven wat er plaats heeft bij poenèn voor krokodil (en hert), lasch ik hier het verhaal in van het onstaan van de hertenjacht. Volgens Mentaweisch geloof n. l. boden de herten zich in vroeger tijden zelf aan, en had men ze slechts te grijpen en te dooden.

Op zekeren dag waren eenige Mentaweiers in het bosch bezig, een boot te vervaardigen. Daar kwam een hert, en zeide: "konankam, alakam ibamoei», d.w.z. "komt, neemt mij tot $U$ als spijs». De mannen namen het hert, verorberden het, en hielden poenèn. Na eenige dagen, toen zij weer in het bosch aan den arbeid waren, kwam opnieuw een hert: "konankam alakam ibamoei». De mannen handelden als de eerste keer. Eenigen tijd later werden de lieden ten derden male in hunnen arbeid gestoord door een hert, dat zich kwam aanbieden. Hoezeer zij anders ook met onvermengde vreugde hertevleesch aten en poenèn hielden, thans wilden zij niets daarvan weten, omdat - op deze wijze voortgaandede boot nooit gereed zou komen. In hun ergernis wierpen zij het hert met een stuk hout. Het beleedigde hert riep toen uit: "tot straf dat gij naar mij geworpen hebt, en mij versmaadt, zult gij van nu af aan honden gebruiken om mij te vangen!»

Bij poenèn voor den krokodil wordt in de eerste plaats een uit hout gesneden vogel in de oemah sabeoe opgehangen, bij wijze van versiering. Verder worden twee lange bamboestengels met bloemen, kralen en bonte lapjes versierd, vóór het gebouw in den grond geplant, waarna varkens en kippen geofferd worden. Daarna moeten de verontreinigden, of althans een gedeelte van hen, een tocht naar Sipora doen, om daar het 
verderfbrengende stof af te schudden. Omgekeerd komen ook enkele lieden van Sipora naar de verontreinigde oemah. $\mathrm{Nu}$ is de "schoonmaak» al een heel eind gevorderd, en kan men weer zonder gevaar met de leden van de oemah spreken. Hiermede is het eerste bedrijf afgeloopen.

Bij het tweede bedrijf moeten de handen uit de mouwen gestoken worden. Alle prauwen van de betrokken oemah-leden heeten aangetast te zijn door kwade invloeden, en daarom moeten er nieuwe booten gemaakt worden. Is dit werk achter den rug, dan wordt weer poenèn gehouden. Ook de bouwvelden worden beschouwd verontreinigd te zijn, dus: weg ermede en nieuwe aangelegd. En dan weer poenèn. Intusschen komen er natuurlijk ziekten en sterfgevallen voor, zoo goed als in normale omstandigheden. Dan wordt de arbeid gestaakt, en natuurlijk weer poenèn gehouden.

Zoodoende kunnen er jaren mee gemoeid zijn, eer men met poenèn voor den krokodil klaar is.

Poenèn voor het hert is een feest van zegen en van geluk.

Is op de jacht een hert neergelegd, dan worden de gelukkige jagers, de honden en ook de jachtbuit met bloemen en bladeren getooid. Zóó wordt een blijde intocht gehouden in oemah of kampong. Het gedoode hert wordt daarna met den kop op de "zielentrap» van de oemah sabeoe gelegd. De gong weerklinkt, en alle mannen verzamelen zich in vroolijke stemming in de oemah sabeoe. Dan komt de priester met geraspte klapper en roept de ziel van het hert, die in het bosch achtergebleven is. $\mathrm{Nu}$ wordt het intusschen naar boven gebrachte dier door de jongelingen gevild, van het gewei ontdaan en in stukken verdeeld, die hun weg vinden naar groote pannen en bakken. Onderwijl slaat een der mannen op de toedoekat, een soort houten muziekinstrument uit, dat nu eens machtig dreunende, dan weer zacht klagende tonen voortbrengt. Deze "muzikant» gaat tevoren eerst de oemah rond, en houdt beschermend zijne handen boven alle kleine kinderen, opdat bij het hooren van de toedoekat-slagen hunne zieltjes niet zullen schrikken en vluchten, want ziekte zou daarvan het gevolg zijn.

De stukken vleesch worden middelerwijl gekookt of op andere wijze toebereid. Dit geschied zijnde, neemt de priester een stukje van het hart en van het rugvleesch, om dat ten offer te brengen, bij welke plechtigheid alleen de gehuwde mannen tegenwoordig mogen zijn. Ten slotte uit de priester eenige 
spreuken, waarbij de jongelingen, die neergehurkt zitten bij den ingang van de offerplaats, telkens invallen door het slaan en beuken op trommen.

Hierop heeft de uitdeeling van het vleesch plaats. Zoolang het hertevleesch nog niet op is, mogen de mannen geen werk verrichten.

Tot slot - en dit geldt voor alle poenèn - gaan de jongelingen klappers plukken en de gehuwde mannen visch vangen. Klappers en visch worden onderling verdeeld.

In tweeërlei opzicht is de geschiedenis van het hert en den krokodil leerrijk voor ons. In de eerste plaats toont ze ons een dieperen grond dan menig ander oppervlakkig verhaal, omdat wij erin vinden een uitgewerkt beeld van het goede en het kwade, van zegen en van vloek.

In de tweede plaats doet ons het verhaal een blik slaan in het dagelijksch leven van het volk, maakt het ons eenigszins vertrouwd met zijn gewoonten, leert het ons eenig huisraad kennen, enz. Zoo zien we b.v. dat de man op vischvangst uitgaat (de vrouw vischt alleen met het schuifnet), terwijl de vrouw het overige voedsel vergaart. $\mathrm{Zij}$ gaat vruchten en knollen halen, kookt het eten, enz. Men leert, op welke wijze het eten toebereid wordt, n.l. in bamboekokers, die op het vuur gezet werden, en dat die bamboes opengespleten worden als de spijs gaar is. Men ziet, dat de kinderen gezoogd worden tot zij eenige jaren oud zijn (zooals trouwens meer bij Indisehe volken voorkomt); het broertje toch, dat reeds het ondeugende besef had, het goede voedsel te verwisselen met slangen en schillen, krijgt later in het bosch moeder's borst. Het verhaal doet ons zien dat de kampongs aan een rivier gelegen zijn; de rivier diende den kinderen zelfs tot wegwijzer, toen het hert hen verliet. Ook zien we op echt Mentaweische wijze een vuilnishoop vlak bij het huis van Goeloebena. Waar in den aanvang van het verhaal man en vrouw in wilden echt samenwonen en uit dien echt kinderen gesproten zijn, sluit Goeloebena daarentegen met het meisje een behoorlijk huwelijk, al is het op primitief Mentaweische manier. Als later de kinderen hun vader herkennen, noemen zij hem teteoe (weduwnaar) in plaats van vader; de moeder is immers, zoo al niet overleden, toch niet meer de vrouw van hun vader. Glazen of mokken om uit te drinken, bezit de Mentaweier niet want het is een 
drinknap (gewoonlijk een klapperdop) waaruit de vader drinkt, en die aan diens lippen blijft vastkleven.

De legende, die ik nu wil vermelden, is op ethnologisch en anthropogenisch gebied niet zonder belang. Ze doet ons zien, dat het begrip "aarde» zich bij den Mentaweier niet veel verder uitstrekt dan het eiland Sumatra. Deze legende is eenigermate samengeweven met het vroeger gegeven verhaal omtrent de scheiding der eilanden Noord- en Zuid-Pageh. Ik merk op dat dit verhaal op verschillende manieren verteld wordt. De vorm, waarin het hier volgt, geeft dunkt mij het best den hoofdinhoud weer.

\section{De schepping van de aarde en van het eerste menschenpar.}

Een hemelgeest wierp aarde omlaag. Zoo ontstond Sumatra. Hij maakte dieren en boomen. Daarna een man en een vrouw. Het ergerde den geest dat die beide menschen niet paarden; de dieren deden het wel. De geest toonde het menschenpaar, hoe de honden het deden. Man en vrouw volgden dat voorbeeld. Er kwamen zeer veel menschen. De menschen zagen, hoe de krokodil zich in en op het water bewoog, konden het echter niet nadoen. De krokodil leerde hen schepen maken. Daarmee reisden velen naar Siberoet. Gedeeltelijk bleven die lieden daar, gedeeltelijk keerden ze terug naar Sumatra.

De hemelgeest verscheen aan hen, die Siberoet bevolkt hadden en zeide hun een heupband van boomschors te dragen. Ze moesten geen gebruik maken van geweven stoffen, ook niet van ijzer. Ook moesten ze niet trachten te weten te komen, hoe een en ander vervaardigd werd, anders zouden ze hunne gezellen, die op Sumatra waren, niet meer terugzien. Een gedeelte hunner ging scheep naar Pageh. In dien tijd kwam van daar een groote, booze vogel naar Siberoet gevlngen. Het was een manjang; deze at vele menschen van Siberoet op. Degenen, die naar Pageh gereisd waren, bleven gedeeltelijk daar achter en keerden gedeeltelijk terug naar Siberoet, waar zij velen hunner gezellen misten en vernamen dat die verslonden waren door den manjang. Daarop voeren ze naar Sumatra terug, en vertelden daar dat slechts weinig menschen overgebleven waren op Siberoet, daar de manjang er velen 
had verslonden. Toen gingen die van Sumatra naar Pageh, om den vogel te dooden. $\mathrm{Ze}$ vonden den vogel in een nest in een hoogen boom, en zetten zich aan het werk, dien boom te vellen. Wat overdag van den stam was weggekapt, groeide 's nachts echter weer dicht. Toen kapten ze dag en nacht door. Eindelijk viel de boom, de vogel vloog weg naar Sumatra, waar hij stierf.

Tot zoover de legende, waarvan het laatste gedeelte overeenkomt met het verhaal betreffende de scheiding van $\mathrm{N}$. en $\mathrm{Z}$. Pageh. Mag men een kern van waarheid in deze legende aannemen, dan zijn enkele conclusies te trekken met betrekking tot de eerste bevolking der Mentawei-eilanden.

$1^{\mathrm{e}}$. Het oorspronkelijke volk woonde op den vasten wal van Sumatra, en kende niet eens het bestaan van schepen; wist niets van Siberoet of van Pageh (die eilanden bestonden vermoedelijk toen niet als zoodanig, en waren één met den vasten wal van Sumatra).

$2^{\mathrm{e}}$. Eerst later is het volk zeevarend geworden (toen de Mentawei-eilanden losgescheurd waren van Sumatra).

$3^{\text {e }}$. Siberoet was oorspronkelijk niet door andere volken bewoond, het werd van Sumatra uit bevolkt. Evenzoo werd Pageh (Noord- en Zuid-Pageh vormden toen nog één eiland) bevolkt van Siberoet uit. (Van Sipora wordt merkwaardigerwijze in 't geheel niet gerept).

4. Er heeft nu en dan verkeer plaats gehad tusschen de Mentawei-eilanden en Sumatra.

$5^{\mathrm{e}}$. Op de Mentawei-eilanden kende men voorheen het gebruik van textiele stoffen en van ijzer; de bewerking kende men niet. $\mathrm{Om}$ de een of andere reden (gestremd verkeer met Sumatra?) kwam er gebrek aan beide, men nam zijn toevlucht tot boomschors en koos pijl en boog tot wapen. Hier zonk dus het volk terug tot lagere beschaving, vermoedelijk wegens gebrek aan ambachtslieden, die ò naar Sumatra teruggegaan zullen zijn, of misschien in een epidemie of catastrophe zijn omgekomen. Dit laatste kan uitgebeeld zijn in den geheimzinnigen vogel, die de menschen verslond.

$6^{\mathrm{e}}$. Tusschen Sumatra, Siberoet en de Pageh-eilanden heeft van ouds onderling verkeer plaats gehad.

De enkele mij bekende andere verhalen, zijn m. i. te onbeduidend om hier te worden medegedeeld.

Dl. 70 . 


\section{HOOFDSTUK V.}

Middelen van bestaan, cultures, landbouw, veeteelt, jacht, visscherij, voortbrengselen, handel, nijverheid, seheepvaart, voedingsmiddelen.

Middelen van bestaan. De middelen, waarin de Mentaweier zijn bestaan vindt, zijn weinig talrijk. Het eigen land levert voldoende op, om in zijn onderhoud te voorzien. Eigenlijke ambachtslieden of geletterde menschen bevinden zich onder het volk niet, zoodat er niemand is, die geregeld loon trekt uit zijn arbeid. Wel gaan soms Mentaweiers in loondienst bij Maleiers of Chineezen, om rotan te zoeken, te helpen bij coprabereiding, enz., doch dit zijn tijdelijke werkzaamheden. Zij worden voor die diensten zelden in geld schadeloosgesteld, doch meestal in ruilartikelen.

Hierboven werd gezegd dat er geen eigenlijke ambachtslieden voorkomen onder de Mentaweiers. Elke man kan hout bewerken, visschen, enz. Bepaalde houtkappers en visschers zijn er dus niet. Klappers plukken kan ook iedereen; veel andere werkzaamheden verricht de man niet. Het bebouwen van ladangs en dergelijke inspannende arbeid is het deel van de vrouw. Alle vrouwen zijn daarin bedreven. Niemand behoeft dus zijn toevlucht te nemen tot meer ervarenen.

De Mentaweier heeft al zeer weinig voor zijn levensonderhoud noodig. Het veld levert hem zijn gewassen, het bosch wild, de rivieren en de zee bevatten visch. Hoe gaarne hij ook rijst eet, hij verbouwt dat product niet, doch betrekt het van vreemde handelaren. Evenzoo tabak, suiker, enz. Ook zijn ijzerwerk, vele soorten huisraad, gereedschappen, enz. verkrijgt hij van die handelaren door ruiling.

Cultures. De voornaamste cultuur (ook van belang voor den uitvoer) is die van klappers. De Mentaweier doet zeer veel aan klappers planten. En met reden, hij gebruikt veel klapper bij zijne maaltijden, terwijl hij ook zijne varkens en kippen ermede voedt. Niet alleen deze omstandigheid, doch ook de ruilhandel spoort hem aan tot klappercultuur. Want de handelaren nemen gaarne klappers in ruil voor hunne waren.

Het is wel dienstig, een oogenblik langer stil te staan bij 
deze cultuur, omdat de Mentawei-eilanden superieure klappers, en diensvolgens waardevolle copra opbrengen.

De verspreiding van den klapperboom heeft in het algemeen plaats doordien handelaren en planters de noten aanvoeren, anderzijds door aanspoeling. De aan het zeestrand staande klapperboomen laten vruchten in zee vallen, en deze worden door de zeestroomen naar andere kusten gespoeld. De ondoordringbare huid zorgt, dat de vrucht goed geconserveerd blijft. Zoo is het te verklaren, dat men op de Pageh-eilanden, voornamelijk op de kleinere daarbij behoorende eilandjes, klapperbosschen. ziet, waarvan de boomen schots en scheef dooreenstaan. Gebrek aan zachten wortelgrond maakt overigens, dat de boomen allerlei hellingen aannemen.

Deze vanzelf ontstane tuinen breiden zich verder uit, en waar menschenhanden niet tijdig te hulp komen, ontstaat een chaos van klapperboomen, die inferieure vruchten dragen. Deze wijze van groeien treft men in hoofdzaak aan op weinig genaakbare plaatsen. Toch is er merkwaardiger wijze haast geen klapperboom aan te wijzen, of de een of andere Mentaweier noemt zich daarvan eigenaar.

Dampkring en temperatuur op de Pageh-eilanden zijn zeer gunstig voor de klappercultuur. De klapperboom heeft n.l. een vrij groote mate van vochtigheid in den dampkring noodig, en kan geen temperatuur verdragen beneden $10^{\circ}$ Celsius. De Pageh-eilanden nu kunnen bogen op een vrij hoogen graad van dampkringsvochtigheid, terwijl een zoo lage temperatuur als boven aangegeven, er niet voorkomt.

Wat de bodemgesteldheid aangaat, - als bekend mogen we aannemen, dat de klapper bijzonder voorspoedig groeit aan de zeekust, wegens de ziltige lucht en den zouthoudenden bodem. De Pageh-eilanden met de talrijke kleine eilandjes bieden daarom veel vruchtbaren grond voor den klapperboom. Een andere gunstige grondsoort vormen de goedgedrenkte rivieroevers. Ook deze grondsoort vindt men voldoende op de beide hoofdeilanden; verschillende groote rivieren dringen diep het binnenland in en de benedenloop wordt gedurig door banjirs bezocht. Verder groeit de klapperboom gaarne op rooden leemgrond, dien men ook hier en daar op de Pageh-eilanden aantreft. Behalve in het binnenland en op enkele kuststrooken vindt men op de Pageheilanden dus overal een gunstigen bodem. 
Doet de natuur alzoo zeer veel, om den Mentaweier de klappercultuur gemakkelijk te maken, deze van zijn kant "laat violen zorgen». Van een behoorlijke wijze van planten, van verzorging en van bemesting, heeft hij niet het minste begrip. Hij oogst de vruchten slechts dan als hij ze noodig heeft, hetzij voor voedsel, hetzij om oogenblikkelijk noodige inkoopen te doen (ruilhandel).

Er bestaan vele voorschriften en wenken, waaraan men zich bij het planten van klappers te houden heeft. Als ik enkele daarvan hieronder zeer in 't kort vermeld, dan zal ieder, die kennis genomen heeft van de beschrijving van den Mentaweischen volksaard, grif toegeven, dat al die zaken boven verstand en werklust van den Mentaweier gaan.

Selectie van bibit-vruchten, beschermen tegen witte mieren, in rijen uitleggen, vochtig houden, in het geschikte jaargetijde uitplanten. In regelmatige rijen plantkuilen maken, zorgen voor licht en zonnewarmte, onkruid verwijderd houden. De jonge planten beschermen tegen klapper-torren, witte mieren en snuit-kevers, den omtrek rein houden, bemesten.

De Mentaweier plant zijne klappers op de volgende wijze. Hij neemt zonder voldoende selectie eenige noten en hangt die op aan een boomtak of aan een staak, tot ze beginnen te ontspruiten. Daarna plant hij ze hier en daar uit, waar het hem goeddunkt. Moeder Natuur moet maar verder zorgen dat de boomen groeien. Dragen de boomen rijpe vruchten, dan plukt hij die, tenminste ... als hij ze noodig heeft.

De vruchtschil, waarvan de vezel zoo bruikbaar is voor het maken van touw en van matten, wordt door den Mentaweier weggeworpen, bij voorkeur ter plaatse, waar de noot geplukt is. Daardoor ontstaan vuilnishoopen, die broedplaatsen worden van voor den klapperboom schadelijke insecten.

Copra bereiden doet de Mentaweier niet; dit laat hij over aan Maleiers en Chineezen, aan wie hij de klappers aflevert. Ook wint hij zelden olie uit klappers.

De overige cultures van den Mentaweier zijn berekend voor eigen gebruik, en hebben niet veel te beteekenen. Zoo verbouwt hij hier en daar suikerriet en sporadisch wat tabak.

Vruchtboomen houdt de Mentaweier er veel op na; die zijn gemakkelijk te planten en hij besteedt daaraan zoo mogelijk nog minder zorg dan aan zijne klapperboomen. De pisang- 
aanplant vereischt meer zorg voor aanleg en onderhoud, vandaar dat men die weinig aantreft.

Landbouw. Evenmin als zijn klapperaanplant, bemest de Mentaweier zijn ladang, die hij zelfs nooit braak laat liggen. Is de grond uitgeput, dan legt hij een nieuwe ladang aan. Op zijn ladang verbouwt hij in hoofdzaak suikerriet, knolgewassen en soms lombok.

Vermelding verdient nog het verbouwen van kladi, een knolvrucht, die een vochtigen bodem noodig heeft. De Mentaweier houdt er speciale kladi-ladangs op na, die soms uitgestrekte moerassen vormen.

Voor de merkwaardigheid vermeld ik nog hier mijn pogingen, om den Mentaweier djagoeng (maïs) te doen verbouwen. Ik verstrekte daartoe aan eenige kamponghoofden zaad, met de mededeeling, dat zij dit moesten uitplanten en dat ik mij over eenigen tijd ervan zou overtuigen, hoe dit zaad zou zijn opgekomen. Daartoe moesten zij het zaad uitplanten in de kampong; de eerste oogst zou bestemd zijn voor uitplanten op de ladangs. Toen ik naar de jonge planten kwam kijken, vond ik in sommige kampongs niets, in andere kampongs een enkel armoedig plantje. Wat was er gebeurd? Enkele kamponghoofden hadden den lust niet kunnen weerstaan, de smakelijke korrels op te eten, anderen hadden ze toch op de ladangs laten uitplanten. Wat in de kampongs was aangeplant, had men in den harden, onomgespitten grond gezet, en wat daarvan nog het levenslicht had aanschouwd, was grootendeels een prooi der kippen geworden.

Veeteelt. Reeds bij de beschrijving van de fauna en bij de opsomming der huisdieren vonden we den Mentaweier niet in het bezit van koeien, paarden, karbouwen, schapen en geiten.

Als slachtvee heeft de Mentaweier alleen varkens en kippen. We hebben gezien, dat de varkens vroeger een onderkomen vonden onder de woonhuizen, en dat ze ongestoord in de kampongs rondliepen. $\mathrm{Nu}$ behoort zulks tot het verledene; de dieren zijn verbannen naar stallen buiten de kampongs; tenzij men zich de moeite bespaart stallen te bouwen, en ze vrij laat rondloopen.

Het bevel, om de varkens buiten de kampongs te houden, werd aanvankelijk nog al met misnoegen ontvangen. Men be- 
greep niet, waartoe die nieuwe regeling diende, men zag er het nut niet van in. 't Was zoo practisch, de varkens in de kampong te houden, meende de Mentaweier. Ze haalden de menschelijke uitwerpselen onder de huizen vandaan; verder gaf men ze wat klapper en kladi te eten, en klaar was men met de voedering. Omdat de varkens buiten de omheining van de kampong datgene misten, "wat de mensch reeds gegeten had", zou het op den weg van den Mentaweier liggen, ze extra te voeren, doch daarvoor is hij te lui. Algemeen werd toen geklaagd, dat de dieren mager werden en verhongerden. Er was veel gegronds in die klacht, doch de fout school bij den Mentaweier zelf. Vóór de nieuwe regeling had men eenvoudig het voor de varkens bestemde voer onder het woonhuis of dicht daarbij te deponeeren ${ }^{1}$, terwijl men na die regeling "heelemaal» naar de omheining van de kampong moest loopen. Dat was nu weer een extra karwei, waar de Mentaweier niet aan wilde; liever dan elken dag een paar minuten te loopen, liet hij de varkens honger lijden. En hij pruilde, omdat een bestuursmaatregel oorzaak was van den achteruitgang van zijn varkens. Toen werd hij met zachten dwang ertoe gebracht, de dieren ook op hun nieuw terrein voedsel te brengen, en dien grond tevens te bestemmen voor plaats, waarheen zelfs de keizer te voet gaat. Men bouwde allengs buiten de kampongs een soort hutjes op palen, waar het voedsel voor de varkens wordt toebereid en waaronder de dieren stalling vinden. Met den nieuwen toestand raakte de Mentaweier op den duur verzoend.

Zich bepaald toeleggen op de varkensteelt doet de Mentaweier niet. Hij mest de dieren niet, en legt zich niet toe op rasverbetering. De varkens telen zich in het wilde voort.

Aan het fokken van kippen laat de Mentaweier zich evenmin veel gelegen liggen. Zelden treft men een kippenhok aan; in de kampong schieten de kippen zich op in het voorgedeelte der woonhuizen, op de ladangs zijn de ladanghuisjes hun toevluchtsoord. Ook deze dieren telen zich voort zonder eenig toezicht van den eigenaar.

Eenden houdt de Mentaweier er hoogst zelden op na.

Jacht. Er zijn slechts twee soorten wild, waarop de Mentaweier jacht maakt, n.l. herten en apen. Op de jacht bedient

1 Als troggen worden veelal reuzenschelpen gebruikt. 
hij zich van pijl en boog, terwijl op de hertenjacht ook wel de lans gebruikt wordt. De Mentaweische hond bewijst bij laatstgenoemde jacht uitstekende diensten. De bosschen herbergen veel herten; de Mentaweier bezit honden, wier speuren, aanvallen en vasthouden bewondering afdwingen, hij bezit wapens van voldoende capaciteit voor deze jacht; - men zou dus met grond verwachten, dat er veel op herten gejaagd wordt. Toch is dit niet het geval. Doch steeds, wanneer een hert in de nabijheid van een kampong komt, wordt er jacht op gemaakt; en ook, wanneer een weinig schuw hert zich aan een of meer menschen vertoont. Dit houdt natuurlijk verband met de legende waarin het hert zichzelf den mensch aanbiedt, om tot spijs te dienen. In die legende straft het hert den mensch, die het aanbod van de hand sloeg; welnu, als de Mentaweier niet zou jagen op een hert, dat, door zich weinig schuw te toonen, blijken geeft, zich te willen aanbieden, dan zou hem opnieuw straf dreigen!

Behalve op drijfjachten, worden ook wel herten gevangen door het spannen van strikken of het stellen van randjoes (scherp aangepunte bamboes).

Bij de jacht op apen verspreiden de jagers zich in het bosch, en stellen zich behoedzaam op achter een boom, of verbergen zich in een boschje terwijl ze zich nu en dan sluipend verplaatsen, tot er een aap onder schot komt.

Een enkele maal wordt wel eens getracht, krokodillen te vangen, n.l. wanneer deze dieren menschen aanvallen, varkens of honden weghalen e. d. g. Dan wordt een val uitgezet, waar de krokodil een grooten rotanstrop om het lijf krijgt, waarin hij blijft hangen.

$\mathrm{V}$ is s c he rij. De vischvangst is een voor-

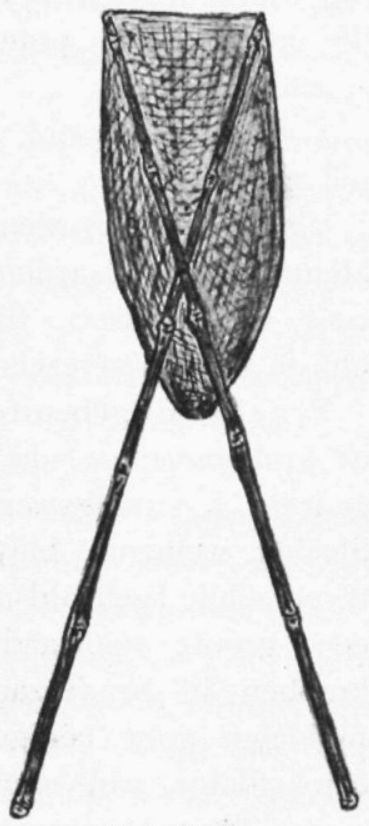

Schuifnet. name bezigheid van den Mentaweier. Hij vischt met netten en met vischlijnen, soms ook gebruikt hij fuiken. Over het algemeen is visschen het werk van den man; de vrouw vischt alleen met een soort schuifnet. Dit bestaat uit twee bamboes, ongeveer 
3 M. lang, die draaibaar aan elkaar verbonden zijn op de wijze van de beide deelen van een schaar; het draaipunt ligt op omstreeks $\frac{1}{3}$ gedeelte van de lengte: Tusschen de korte beenen is een net aangebracht. Met dit net uit visschen gaande, begeven de vrouwen zich naar de riviermonding aan het strand, of wel naar zandplaten of kleine eilandjes; in het algemeen daarheen, waar laag zeewater staat. Dan gaan zij te water (hoogstens tot aan de heupen), het net, dat op den zeebodem rust, aan de lange armen aanvattende, en zoo vóór zich uit schuivende. Na eenigen tijd wordt, door de uiteinden der bamboes naar elkaar toe te brengen, het net gesloten, en uit het water getild. De buit bestaat meestal uit kleine vischjes, garnalen, e. d. g.

Het visschen met de lijn geschiedt zonder hengel. De Mentaweier gaat daartoe met zijn prauw naar zee, op eenigen afstand van de kust, liefst in diep water. Voor deze visscherij kiest hij bij voorkeur den tijd na een flinke regenbui; dan vertoonen de verschillende prauwtjes zich in de verte als onbeweeglijke zwarte stippen.

Voorts wordt ook visch bemachtigd door het schieten met pijl en boog.

Vischnetten worden voor een groot gedeelte ingevoerd. De Mentaweier vervaardigt ze echter ook zelf; dat is dan een werk voor de vrouwen, die het daartoe benoodigde garen winnen uit de boombastvezels van de menindjau (gnetum gnemon).

Een heele gebeurtenis in het leven van den Mentaweier is de krabbenvangst, die plaats heeft bij volle maan. Dan trekken geheele kampongs er op uit, mannen zoowel als vrouwen. Slechts weinigen blijven achter. De grootste prauwen worden tevoorschijn gehaald en opgetuigd met mast en zeilen, terwijl een groote voorraad korven wordt medegenomen (om de krabben in te verzamelen), benevens een hoeveelheid levensmiddelen voor eenige dagen. Soms wordt op de prauw nog een afdakje van atap gebouwd. Deze groote prauwen kunnen soms 20 en meer personen bevatten. Het is werkelijk een interessant gezicht, zoo'n vlootje van die prauwen te zien uitvaren. Als de wind niet toelaat de zeilen te gebruiken, dan hanteeren tientallen rappe handen de roeispanen (pagaaien), en doen de ranke vaartuigjes snel vooruitschieten. Vroolijk en luidruchtig gepraat en gelach klinkt uit de prauwen, nu en dan 
onderbroken door een langgerekt geluid of door een eentonig geneuried wijsje. Allen zijn vol goeden moed, en verheugen zich reeds bij voorbaat op den te vangen buit.

Het vlootje zet koers naar het een of ander strand, waar men veel krabben weet. Daar ontscheept men, of wacht men in de prauwen het vallen van den avond af. De krabben houden van licht, en loopen bij het volle maanlicht bij massa's over het strand. Bovendien zijn ze bij het van nabij zien van een lichtbron a.h.w. gefascineerd, en blijven dan stil staan.

$\mathrm{Nu}$ begint de pret van het vangen. Het visschersgezelschap verspreidt zich over het strand; elkeen is voorzien van een brandende fakkel en van een tang, vervaardigd van een dubbelgeslagen reep bamboe; bovendien wordt op den rug een korf gedragen. Nu worden de fakkels dicht bij den grond gehouden; nieuwsgierig komen de krabben aangeloopen, om vlak bij het licht van de fakkels zich onbeweeglijk te houden. Dan grijpt men ze met de tang, en werpt ze over het hoofd heen in den mand op den rug. Zoo wordt een groot gedeelte van den nacht doorgebracht.

$\mathrm{Op}$ een afstand gezien, levert zoo'n krabbenvangst een fantastisch gezicht op. Men ziet de talrijke fakkels zich als dwaallichtjes over het strand bewegen en zou daar geen menschen vermoeden, ware het niet, dat nu en dan een schreeuw of gezang weerklonk.

$\mathrm{Na}$ eenige dagen keert de visschende gemeente huiswaarts, "de kielen zwaar belaân» met krabben.

Voortbrengselen. De voortbrengselen van de Pageheilanden zijn van geringe verscheidenheid en nagenoeg alle reeds vermeld, hetzij bij de beschrijving van de plantenwereld, dan wel van de cultures.

Voor den uitvoer zijn van het meeste belang klapper en rotan. Rotan zoeken is een vrij zwaar werk, weinig naar den zin van den Mentaweier. Daarom laat hij dit liever over aan den Maleier, die bij het zoeken naar rotan tevens damar verzamelt.

Reeds is vermeld, dat de klappers voor den Mentaweier een voornaam betaalmiddel vormen, wanneer hij zich iets van de vreemde handelaren wenscht aan te schaffen. Deze handelaren voeren groote hoeveelheden klapper uit, na ze vooraf tot copra 
verwerkt te hebben. Deze wordt verscheept naar Padang, waar Europeesche en Chineesche handelshuizen ze opkoopen, en vanwaar ze veelal verhandeld wordt naar de.Straits.

De op de Pageh-eilanden gewonnen rotan volgt met scheepsladingen denzelfden weg.

Een ander voortbrengsel, alleen voor uitvoer bestemd, is tripang die door Maleiers verzameld wordt.

Ook moet hier vermeld worden schildpad, gretig door de handelaren opgekocht. Het bruikbare schildpad levert alleen de zeeschildpad, waarvan het vleesch door de Mentaweiers als lekkernij gegeten wordt.

Verder verzamelen de Chineezen haaienvinnen, een voor hen bijzondere delicatesse, die via Padang haren weg vindt naar China.

Dan vindt men er nog was van wilde bijen; voorzoover mij bekend is, komt dit artikel niet voor uitvoer in aanmerking.

De eilanden brengen veel sago voort, doch dit product is uitsluitend bestemd voor consumptie door de bevolking.

Handel. Omdat de Mentaweische bevolking op een lagen trap van beschaving staat, en zichzelf niet kan voorzien van velerlei nuttigs en fraais, heeft er een levendige handel plaats. Maleiers en Chineezen van Sumatra (voornamelijk van Padang) hebben hier en daar aan de kust een huisje gebouwd met een magazijn er bij, en soms nog een afzonderlijke loods voor het opschuren van copra e. d. g.

Daar in hun kleine nederzetting hebben de handelaren in voorraad: ijzeren gereedschappen, rijst, zout, suiker, kleedingstukken, geweven stoffen, petroleum, kookpannen, braadpannen, lampen, houten koffers, kralen, spiegeltjes, koekjes, biscuit, bamboehoeden, vischtuig, touw, spijkers, tabak, lucifers, koperdraad, aardewerk, messen, enz. enz. Hunkerend van verlangen staat soms de Mentaweier naar al dat fraais en nuttigs te kijken, in zijn binnenste een strijd voerend, of hij daar klappers zal brengen, om zich het een en ander aan te schaffen, dan wel of hij terug zal keeren naar zijn kampong en zich aan een zalig nietsdoen, zal overgeven.

Tot vóór korten tijd was geld als ruilmiddel onbekend op de Pageh-eilanden; zoo waren èn kooper èn verkooper genoodzaakt, goederen te ruilen. Thans is die toestand in zooverre 
veranderd, dat de Mentaweier overal geld aanneemt als betaalmiddel. Hij geeft het echter zelden of nooit meer uit, en zoodoende blijft hij zijne inkoopen in natura betalen. Vele Mentaweiers scheppen er behagen in geld op te zamelen, niet om dit op nuttige wijze te besteden, doch om het thuis ergens weg te stoppen. Groot is hun vreugde, als zij eenig klein geld bijeen hebben, en dit kunnen wisselen tegen grootere muntsoort. Zoo kwamen sommigen dagen ver roeien naar mijn standplaats, om hun opgezameld geld te kunnen omzetten in een kwartje of in een gulden! Velen van die numismatisch aangelegden overwinnen hunne apathie, en steken een enkele keer de handen uit de mouwen, halen klappers, rotan en vruchten, of vangen visch en verkoopen die tegen geld.

Hieruit blijkt hoe het geld "opvoedende kracht» bezit, en een middel is, om den Mentaweier tot arbeiden te brengen. Ten einde in deze richting verder te werken, riep ik te Lawang Toengkoe een Zaterdagschen marktdag in het leven. In een eenvoudige pasarloods nabij het strand hadden de Mentaweiers gelegenheid alles aan den man te brengen, wat zij wilden verkoopen. De eerste pasardag reeds bracht een honderdtal Mentaweiers samen, allen glimlachend om het vreemde, onbekende gebeuren. Met bewonderenswaardig geduld bracht een politie-soldaat eenige orde onder de slechts half-begrijpende menschen, zoodat ongeveer gelijksoortige koopwaar bijeen was uitgestald. De meesten hadden klappers meegebracht; een welkome waar voor de militaire bezetting vormden visch, vruchten (w. o. pisang) en lombok. Daar waren enkelen, die een haan of een kip te koop boden; velen (voornamelijk knapen) verkochten kippeneieren. Anderen hadden wat groenten medegebracht: cassave-bladeren en katjang pandjang (Vigna sinensis). Midden tusschen die allen zat, dom lachend, een Mentaweier gehurkt, als eenig artikel voerend een landschildpad, vastgebonden aan zijn grooten teen! Een ander was verschenen met één laboe (soort pompoen), waarvoor hij een gulden vroeg, ofschoon die met tien centen ruim betaald zou zijn geweest. Over het algemeen heerschte er een zucht tot overvragen, die storend werkte op den verkoop. Na verloop van eenige weken normaliseerden de prijzen zich van zelf.

Deze pasardag was den vreemden handelaren natuurlijk een doorn in het oog. Hier was een gecontrôleerde markt, waar met 
geld betaald werd, dus waar hunne ruilartikelen ondienstig waren. Hier kreeg de Mentaweier veel hoogere prijzen in geld, dan hij anders in ruilgoederen ontving. En nu stond de Mentaweier moreel sterker tegenover Maleiers en Chineezen; omdat hij, bij door hen te laag geboden prijzen, steeds kon dreigen, zijne klappers, enz. ter hoofdplaats aan de markt te brengen.

Als vreemde handelaren werden tot nu toe slechts Chineezen en Maleiers genoemd. Doch ook was ter hoofdplaats een kleine toko gevestigd, eigendom van een Hollander, maar gedreven door een Maleischen zetbaas. De eigenaar van die toko had eenige motorbooten in de vaart tusschen Sumatra en de Mentawei-eilanden, terwijl hij tevens erfpachter was van het eilandje Sandion.

Nijverheid. Van een eigenlijke nijverheid kan bij den Mentaweier niet gesproken worden. Ik zal dus volstaan met een opsomming van de voorwerpen, door het volk vervaardigd, waarbij kan blijken, in hoeverre daarbij eenige kunstzin tot uiting komt.

Een groote behendigheid heeft de Mentaweier in het werken met de bělioek. Hiermede houwt hij zijne prauwen uit zware boomstammen, bij welke werkzaamheid ook zijn parang (kapmes) diensten bewijst. Die prauwen, uit één stuk, zijn dus niet anders dan uitgeholde boomstammen. Met de bělioek vervaardigt hij ook balken en stijlen, die een enkele keer wel eens een ornament dragen. Zoo vindt men in de oemah sabeoe soms een dwarsgebint, waarvan de uiteinden verloopen in een gesneden vogelkop. Den vogel hebben we reeds als ornament ontmoet bij de tatouage. Soms vindt men een vogelmotief gesneden in een plank, die dienst doet als deur of als wandgedeelte.

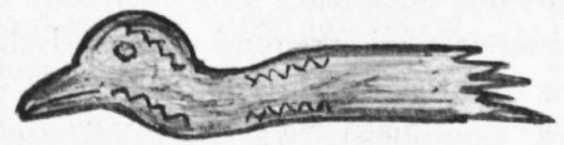

Uiteinde van een bintbalk.

Ander snijwerk vindt men in houten beeldjes en in menschelijke figuren, als reliefwerk aangebracht op het voorvlak van houten stijlen. 


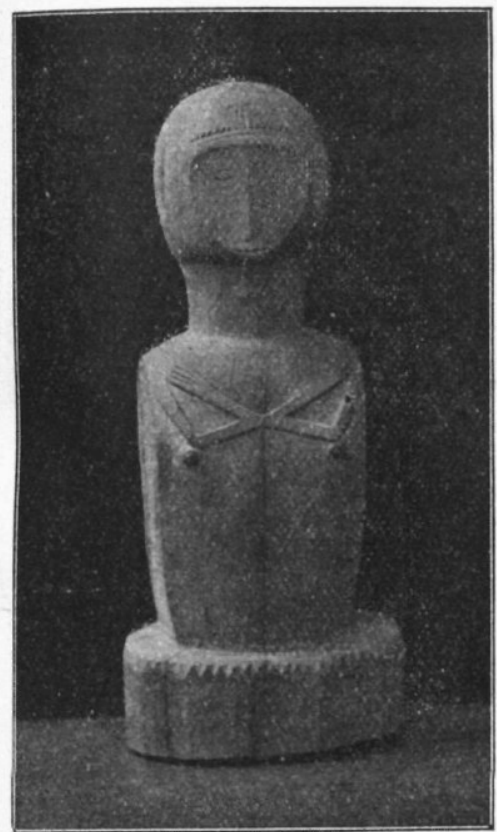

Getrouwe nabootsing van een vrouwelijk beeld aan de bovenzijde van de trap van de oemah sabeoe te Taikako (Noord-Pageh). $\frac{1}{8}$ ware grootte.

(Coll. Koloniaal Instituut).

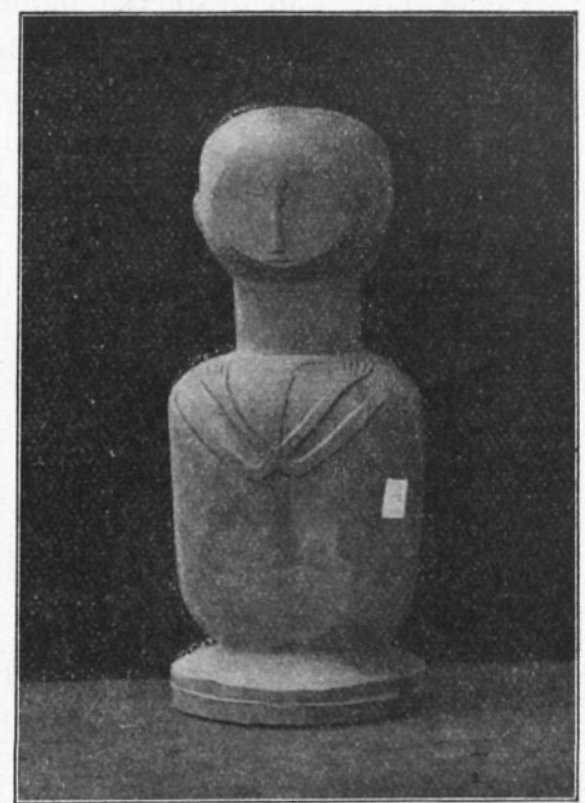

Houten beeld, een manspersoon voorstellende; getrouwe nabootsing vian het beeld aan de bovenzijde van de trap van de oemah sabeoe te Taikako (Noord-Pageh). $\frac{1}{8}$ ware grootte.

(Coll. Koloniaal Instituut).

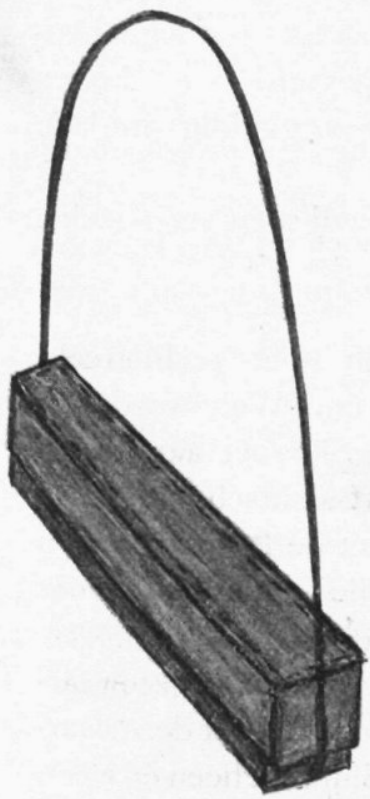

Doos. (Schaal 1:15).

Voor zijne kinderen snijdt de Mentaweier wel eens een klein prauwtje, om als speelgoed te dienen. Dit is van hetzelfde model als de groote prauwen. In de prauwen ziet men soms een waterschep, uit één stuk gesneden van een blok hout.

Van bamboe worden groote en kleine kokers gemaakt, welke de Mentaweier gebruikt bij wijze van reistasch, als hij zich buiten de kampong begeeft. Deze kokers dragen geen versiering, zooals de pijlkokers.

Uit de bladscheede van den niboengpalm vervaardigt de Mentaweier langwerpige doozen met deksel, hetzelfde doel hebbende als de bamboekokers, en die aan een koord over den schouder gedragen worden.

De Mentaweier heeft eenig begrip van 
vlechtwerk. Van gespleten bamboe en rotan vlecht hij manden, draagkorven en vogelkooien. Het vlechten van matten kent hij echter niet. Wel gebruikt hij soms een slaapmat, doch deze wordt vervaardigd van geklopte boomschors.

Fijn snijwerk vindt men in schelpwerk, dat voorkomt aan de halsversieringen.

Kleurwerk treft men aan bij de in oemah sabeoe opgehangen hertengeweien en botten, darmen en blazen van herten en apen. Deze voorwerpen nl. zijn soms bestreken met een gele of zwarte verfstof. Sierlijk is dit werk niet; het bepaalt zich tot eenvoudige lijnen of krullen.

Van boombastvezels wordt een ruw soort garen vervaardigd. Ook makt men touw van reepen boombast, die vooraf door kloppen soepel gemaakt wordt.

De Mentaweier weet zelf zijn zeilen voor de prauwen te vervaardigen, d. w. z. het (dunne) zeildoek koopt hij bij de handelaren; dit snijdt hij op de vereischte afmeting en hecht voor zoo ver noodig de banen aaneen. Soms ook ziet men kleinere zeilen, verkregen door samenvoeging van oude en nieuwe lappen van allerlei kleur.

Een proeve van lederbereiding treft men aan bij inlandsche trommen. Deze voorwerpen, waarvan de ketel bestaat uit een rond, uitgehold stuk boomstam, zijn aan één zijde bespannen met een leersoort, af komstig van herten-, slangen- of leguanenhuid. Dit leer is niet gelooid, doch geprepareerd door drogen in de zon, terwijl de hertenhuid bovendien zorgvuldig ontdaan wordt van de haren.

De door den Mentaweier vervaardigde kleedjes en versierselen hebben we reeds eerder leeren kennen.

Scheepvaart. De Pageh-eilanden zijn niet rechtstreeks aangesloten aan de groote stoomvaartlijnen. Wel wordt de standplaats van den civiel gezaghebber op Siberoet aangedaan door de booten der Koninklijke Paketvaart-Maatschappij. Van daar uit wordt een scheepvaartverbinding met de Pageh-eilanden onderhouden door een motorschoener, die uitsluitend voor militaire en bestuursdoeleinden dient.

De Maleische en Chineesche handelaren beschikken over zeewaardige zeilprauwen in vereenigd- of individueel bezit. Met deze vaartuigen varen zij tusschen de Pageh-eilanden en Sumatra heen en weer. 
De Mentaweier beschikt slechts over kleine prauwen (uitgeholde boomstammen), waarvan de grootste weliswaar een twintigtal personen kunnen dragen, maar die slechts in zooverre

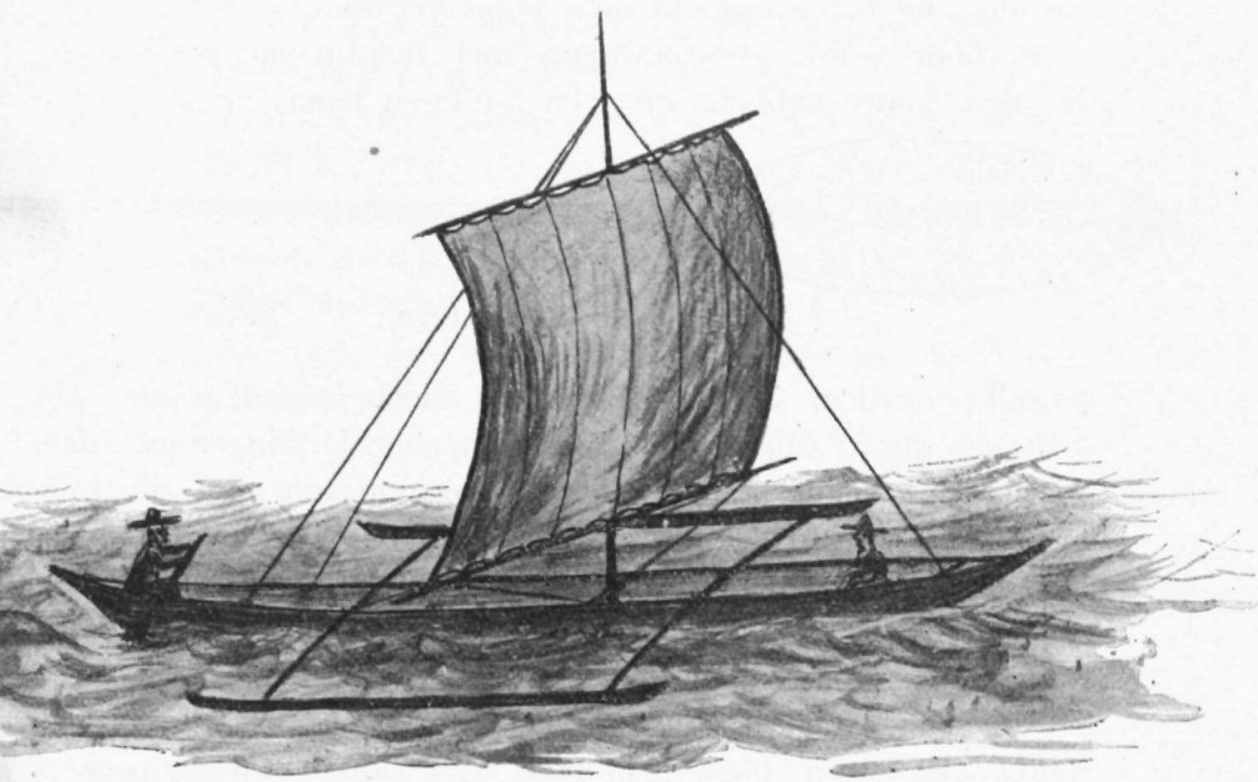

Mentaweische prauw met zeil en vlerken.

zeewaardig zijn, dat men er bij kalm weer van de Pageh-eilanden naar Sipora kan oversteken. Er valt echter niet aan te denken met die vaartuigen, waarvan de bootrand slechts eenige handbreedten boven water uitsteekt, Padang te bereiken. Zij liggen buitendien zeer wankel op het water; bij een weinig overbelasting naar bakboord of stuurboord hellen ze over, en dreigen om te slaan. De Mentaweier is zeer bedreven in het houden van evenwicht in zijn prauw, en zal zelden met zijn bootje omslaan zoolang hij de rivieren bevaart, doch nauwelijks komt hij op zee, of hij bindt de vlerken aan zijn vaartuig. En dit is op het min of meer rumoerige water wel noodig. De vlerkprauw ligt vrij vast, en kan betrekkelijk goed zee bouwen, vooral wanneer het scheepsboord wordt verhoogd met een rand van harde boomschors of van palmscheeden. Dan slaat het zeewater niet spoedig binnen, ook al vangt het zeil veel zijwaartschen wind.

De geliefkoosde houding van den Mentaweier, in zijn prauw varend, is knielend. De onderbeenen liggen daarbij op den 
bodem van de prauw, terwijl de bovenbeenen op de onderbeenen zijn samengevouwen, zoodat zijn zitvlak rust op de hielen. Het geheele lichaam schijnt dan één te zijn met het vaartuig, en het evenwicht gaat nooit verloren.

De boot wordt voortbewogen met behulp van roeispanen, die den vorm hebben van een puntigen lepel, en als pagaai

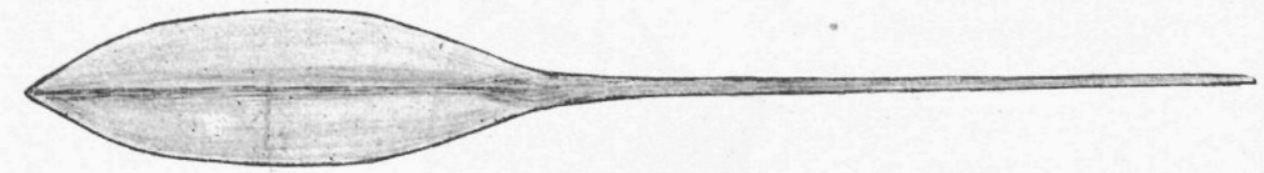

Roeispaan. Schaal 1:12.

gebruikt worden. Zit de Mentaweier alleen in een prauw, dan roeit en stuurt hij tegelijk met zijn pagaai. Zijn er meerdere menschen, dan is het de achterste persoon, die met zijn roeispaan het vaartuig stuurt. Sommige groote prauwen hebben een afzonderlijk roer, dat in vorm niet veel verschilt van een gewone roeispaan.

Mannen, vrouwen en zelfs kinderen zijn zeer bedreven in het roeien, en haast onvermoeid. Zoo goed als alle verkeer heeft over water plaats; loopen doet de Mentaweier weinig. Men zou derhalve verwachten, dat de Mentaweier slecht ter been is. Mijne ondervinding met enkele Mentaweiers, die mij als gids dienden, is echter, dat zij hoogst ervaren woudloopers zijn.

Nog een enkele opmerking naar aanleiding van de weinige zeewaardigheid der Mentaweische prauwen. Aannemende de conclusies, hiervoren vermeld, moet men tot de erkenning komen, dat in vroeger tijden de Mentaweiers beschikten over zeebouwende schepen. Wellicht makten zij toen ook gebruik van de prauwen, zooals zij die thans hebben, doch daarnaast moeten grootere vaartuigen bestaan hebben, uit planken gebouwd, voorzien van zware zeilen, enz. Het volk moet dus in die tijden tamelijk ervaren timmerlieden tot zijne beschikking gehad hebben.

Voedingsmiddelen. De voedingsmiddelen van den Mentaweier zijn grootendeels reeds eerder hier en daar beschreven. Zijn hoofdvoedsel is kladi, die gekweekt wordt op drassige velden. Het is een knolvrucht; de knollen worden in bamboes boven het vuur gaar gekookt en vormen dan een grauwwitte zelfstandigheid. 
Naast kladi gebruikt hij ook zeer veel sago, dat gewonnen wordt uit den sagopalm. De boom wordt daartoe geveld en in blokken gehakt. Deze brokstukken worden eerst in stroomend water geweekt en daarna gespleten; vervolgens wordt het merg losgeklopt of geraspt en verzameld.

Verder wordt bij de maaltijden veel klapper gebruikt en oebi (een wortelvrucht). Overigens bevat het vegetarisch gedeelte van het Mentaweisch menu alles wat het land op dit gebied oplevert.

De Mentaweier nuttigt het vleesch van varkens, kippen, apen en van badjings (inlandsche eekhoorns).

Vleesch is voor den Mentaweier geen dagelijksch voedsel (voor den gehuwden man alleen bij poenèn). Wel echter visch, krabben en garnalen. Soms nuttigt hij schildpadvleesch of inktvisschen. Ook haaienvleesch versmaadt hij niet. Een lekkernij voor hem vormen de larven van den paalworm.

Overigens gebruikt de Mentaweier de voedings- en genotmiddelen, die bij de handelaren verkrijgbaar zijn. Op tabak is hij bijzonder verzot. Hij rookt die, gerold in een gedroogd nipah-blad, of wel in een gewoon boomblad. Ook wel in sigaretten-papier. Heeft hij niets anders, dan draait hij zijn "sigaret» in een gewoon stuk papier. Zoo'n "sigaret» heeft dikwijls de grootte van wat wij een «kloeke» sigaar noemen. Een enkele geavanceerde Mentaweier rookt wel eens tabak in een pijp. Tabak kauwen is hem onbekend, evenals sirih pruimen.

Daar de Mentaweiers geen melkvee bezitten, kennen zij ook het gebruik van melk niet. De enkelen onder hen, die ik melk liet proeven, verklaarden eenparig, dat die afschuwelijk smaakte.

\section{HOOFDSTUK VI.}

Stamleven; huwelijk; erfrecht; rechtspraak; eed.

Stamleven. Het Mentaweische volk leeft in kampongs, waarvan de grootere weer verdeeld zijn in oemah's. Een oemah of een niet onderverdeelde kampong is te beschouwen als één familie, niet gebonden door banden des bloeds, maar door hetzelfde besef, waardoor kudden dieren bijeengehouden worden. De bevolking van een niet onderverdeelde kampong vormt op zichzelf ook een oemah.

Dl. 70 . 
Een regeerend vorst bestaat niet op de Pageh-eilanden. ook hebben kampong noch oemah een regeerend of besturend Hoofd. ${ }^{1}$ Elke oemah is een op zichzelf staand geheel, hare leden vermaagschappen zich onderling. De oemah's van eenzelfde kampong hebben wel omgang met elkander, doch zelden met andere kampongs of oemah's.

Komt het een enkele maal voor, dat een man een vrouw huwt uit een andere kampong, dan is en blijft hij in de nieuwe kampong vreemdeling. Weliswaar krijgt hij gratis een stuk grond in bruikleen, en mag hij daarop een huis zetten en planten wat hij verkiest, maar vreemdeling blijft hij. Sterft zijn vrouw kinderloos, dan zijn alle banden met de kampong verbroken en kan hij gaan. Anders echter wordt de zaak, wanneer hij zich burgerrecht verschaft door aankoop van eigendommen in de kampong. Dan houdt hij op, vreemdeling te zijn.

Omtrent de voormannen der kampong is reeds het een en ander vermeld in Hoofdstuk II.

De kampongs tonnen volstrekt geen solidariteit, een punt van belang, wanneer wij eventueel gedwongen zijn, de wapens tegen het volk op te vatten. Wanneer bv. een kampong verzet pleegt, dan bestaat er oorlog tusschen die kampong en de "kompenie». Andere kampongs, zelfs de dichtbij gelegene, zullen zich onzijdig houden; de strijd hunner buren is hunne zaak niet. Zoodoende zullen wij nooit met een groote troepenmacht behoeven te ageeren, tenzij verscheidene kampongs tegelijk (elk om verschillende redenen) in verzet komen.

Huwelijk. Het Mentaweische volk kent de instelling van het huwelijk, doch hiernaast neemt de z.g. wilde echt een veel voornamere plaats in.

Wanneer de Mentaweische jongeling het met een meisje eens is, gaan zij samenleven. De ouders, hoewel bekend met dien omgang, worden hierin niet gekend. Reeds op 13 à 14 -jarigen leeftijd leeft het Mentaweische meisje in vrije liefde en wisselt meermalen van minnaar. Krijgt zij kinderen bij één of meer mannen, dan is dit volstrekt geen schande; haar vader ver-

1 Een vorst schijnt nooit op de Mentawei-eilanden bestaan te hebben. Men behoeft de verhalen der Oostersche volken in het algemeen slechts na te gaan, om dadelijk gewaar te worden, dat vorsten, prinsen en princessen daarin de eerste plaats innemen; bij de Mentaweische verhalen vindt men zulks niet. 
heugt zich zelfs daarover. Wil een jongeling huwen, dan bekommert hij zich er niet om, hoe zijn aanstaande vroeger geleefd heeft; het is voor hem ook geen bezwaar, dat zij reeds kinderen heeft.

Bij het Mentaweische huwelijk wordt door den jongeling geen koopsom betaald, evenmin worden geschenken van hem geeischt. Alleen geeft hij kralen en andere kleinigheden aan zijne geliefde, om hare genegenheid te winnen. Verder helpt hij zijn toekomstlgen schoonvader nu en dan bij zijn werk, bv. bij het maken van een prauw, of hij brengt hem als geschenk wat tabak, klappers, een bělioek of iets dergelijks.

De vader van den trouwlustigen jongen man gaat met dezen naar den vader van het meisje (bij ontstentenis van den vader treedt een der naaste mannelijke bloedverwanten op), in wiens huis zich ongeveer het volgende gesprek ontwikkelt:

"Vriend, gezel, het is $\mathrm{U}$ niet onbekend, dat mijn zoon een "huis gebouwd heeft. Hier is hij, hij wil Uwe dochter huwen. "Zij willen elkaar wederkeerig hebben, het is nu eenmaal hun "voornemen en zoodoende komen wij hier, om er over te "spreken indien gij wilt."

Dan antwoordt de ander, ironisch en bescheiden:

"Ja goede vriend, gezel, het is goed! Willen onze kinderen "zoo dom zijn, laat hen begaan. Ze hebben het zelf gewild, "het is hun eigen schuld. Wat mijne dochter betreft, ze is nog "een naief, dom ding ${ }^{1}$; ze kan niet koken, niet visschen, geen "kladiveld bebouwen, waarvan moeten die beiden leven? Maar "als ze willen huwen, laat hen begaan, ze moeten het zelf weten."

$\mathrm{Nu}$ gaat het aanstaande echtpaar naar het huis van den jongen man en legt zich daar te slapen. Daarna wordt afgewacht, of de volgende dag wel gunstig zal zijn. De voorwaarden voor een gunstigen dag zijn, dat in den daaraan voorafgaanden nacht niet het vallen gehoord wordt van een boom of van een zwaren boomtak, niet het gekrijsch van een aap weerklinkt en niemand in de kampong sterft.

Is aan deze voorwaarden voldaan, zoodat de komende dag gunstig is, dan komen den volgenden morgen de vrouwelijke verwanten van de bruid hare bezittingen in het huis van den bruidegom brengen: kralen, eetwaren, stukken goed, kookgerei, enz. $\mathrm{Nu}$ begint het poenèn; allen tooien zich met bloemen,

1 Dat naieve ding heeft soms al verscheidene kinderen! 
kralen, enz., er wordt eten toebereid en een kip den huisgeest ten offer gebracht. Dan bidt men om lang leven, om verschoond te blijven van ziekten, om zegen bij den akkerbouw en bij het visschen, enz. Daarna wordt opnieuw een kip geofferd (thans in de oemah sabeoe) waarvan uit de ingewanden nagegaan wordt, of de geesten al dan niet gunstig denken over het huwelijk. $\mathrm{Nu}$ vraagt de jonge man aan den geest van de oemah, het huwelijk te willen goedkeuren. Als dit afgeloopen is, zetten allen zich aan een gemeenschappelijken maaltijd, na afloop waarvan het huwelijksfeest voor de genoodigden geëindigd is.

$\mathrm{Nu}$ moeten de jonggehuwden nog veertien dagen lang poenèn houden, waartoe de aanwezigheid van derden onnoodig is.

De geheele huwelijksplechtigheid gaat buiten bemoeienis van den rimata en den priester om.

De jonge man is nu overgegaan in het kader der gehuwde mannen, meestal tevens is dat der huisvaders. Thans is het gedaan met verschillende vrijheden, hij is onderworpen aan de verbodsbepalingen voor gehuwde mannen. Wordt hij in den gehuwden staat vader, dan staan hem, behalve meerdere werkzaamheden, nog meerdere verbodsbepalingen te wachten. Daarom gaat de jongeling niet spoedig tot een huwelijk over.

Geboorte. Is een vrouw in gezegende omstandigheden, dan moet haar man een menigte voorschriften volgen. Zoo mag hij geen dier dooden, niets planten, geen boom vellen, het veld niet bearbeiden, geen grondwerk verrichten, en over het algemeen geen zwaar werk doen. Ook de vrouw heeft enkele voorschriften op te volgen; o. a. mag zij niets krom of opgerold neerleggen (anders komt het kind krom ter wereld). Doch zij behoeft niet zooveel na te laten als de man; zij toch moet erop uit gaan om levensmiddelen te halen voor het dagelijksch maal. Slechts op het allerlaatst mag zij de kampong niet meer verlaten. Dan komt het grootste deel harer werkzaamheden voor rekening van den man.

Bij de bevalling wordt de kraamvrouw door andere vrouwen geholpen. Wanneer het kind geboren is, dan wordt poenèn gehouden, en den huisgeest een kip ten offer gebracht. Dit wordt gedaan door den vader, in zijn hoedanigheid als huispriester. ${ }^{1}$

1 Wanneer een ongehuwd meisje een kind ter wereld brengt, dan zorgt haar vader voor dit offer. 
De gelukkige vader mag nu in 6 à 7 maanden de kampong niet verlaten; voor elke maand zijn bepaalde poenèn voorgeschreven. De geesten n.l. heeten erg begeerig te zijn naar zoo'n jong wicht. De liefde van de Mentaweiers tot hunne kinderen is bijzonder groot, grenst soms aan het belachelijke. Zoolang het kind nog niet loopen kan, mag het niet alleen worden nedergelegd; 's nachts slaapt het in de armen van de moeder, en over dag wisselen vader en moeder elkaar af bij het dragen van het kind. Wanneer het kind uit handen gelegd zou worden, dan zouden de geesten zich dadelijk op zijn zieltje werpen. Het spreekt vanzelf, dat gedurende al de maanden die de man gebonden is aan de kampong, hij maatschappelijk zeer achteruit gaat; zijn aan haar lot overgelaten ladang b.v. komt vol met onkruid, dat de voedingsgewassen doet verstikken.

Is het kind 3 à 4 dagen oud, dan gaat de moeder er twee maal dagelijks mede naar de rivier, om het te baden. De Mentaweier houdt zulks voor bijzonder gezond; in werkelijkheid vatten de kleine schepseltjes echter dikwijls koude, beginnen te hoesten, en krijgen al spoedig de eerste kiemen van longen borstziekten.

De moeder zoogt het kind, doch geeft het reeds kort na de geboorte tevens vast voedsel (kladi of pisang), dat eerst door haar goed fijngekauwd wordt, en met een slok water tot een vloeibaar goedje gespoeld wordt. Deze voedering heeft bij voorkeur in de rivier plaats, waarbij de vrouwen tot aan het middel in het water staan; het water, dat het gekauwde voedsel tot brei moet maken, wordt uit de rivier opgeslurpt. Is het lekkers fijn gekauwd en vloeibaar gemaakt, dan spruit de moedermond het over in den kindermond. Dat deze voedingswijze aanleiding geeft tot ontsteking van de teere kinderdarmpjes, laat zich begrijpen.

De zoogende moeder draagt over de buste, vlak boven de borsten, een vast aangesnoerden band, met de bedoeling de capaciteit der borsten op te voeren.

De Mentaweier verafgoodt zijne kinderen, en, ware het hem aan zijn verstand te brengen hoeveel ziekte en sterfte hij teweegbrengt door het vroegtijdige baden en het onzinnige voeden der zuigelingen, hij zou die dwaze gewoonten dadelijk nalaten. Doch raadgevingen noch theorieën werken iets uit tegen zijn bekrompen opvattingen.

De veel te ver gedreven kinderliefde is oorzaak, dat er van 
tucht eenerzijds, van gehoorzaamheid anderzijds, geen sprake is. De kinderen doen en laten, wat hun goeddunkt; de ouders denken er niet aan, de bengels met straffe hand te regeeren, Wanneer de ouders hun kinderen een pak slaag zouden geven, dan zou dit oorzaak kunnen zijn, dat de kinderziel op de vlucht gaat, en bijgevolg het lichaam ziek wordt of sterft.

Echtscheiding. Uit de wijze, waarop een huwelijk gesloten wordt, volgt, dat dit uit zuivere liefde voortspruit. Immers, zonder een huwelijk te sluiten, kunnen beide partijen zooveel geslachtsgemeenschap hebben als zij willen; niemand of niets staat hen daarbij in den weg. Van een paar, dat tot een huwelijk besloten is, kan men dus zeggen, dat hen de wil bezielt, voor het verdere leven bijeen te blijven.

Maar, zooals overal ter wereld, komen ook hier ontgoochelingen voor in het huwelijk, en bijgevolg echtscheidingen. Zoo'n echtscheiding gaat zeer eenvoudig in zijn werk: een der echtelieden loopt weg, of wel de vrouw wordt verstooten. De gescheiden vrouw kan geen rechten doen gelden, noch op de kinderen, noch op eenig goed (een vaderrechterlijke instelling dus). In den regel wordt haar uit medelijden een huis en eenig huisraad afgestaan.

Bij de Mentaweiers heerscht strenge monogamie. De jongeling heeft vóór zijn huwelijk in den regel 2 à 3 minnaressen, en bij ieder harer een of meer kinderen. Indien hij een harer huwt, blijven de anderen zitten, tenzij een andere jongeling haar tot minnares kiest. Krijgen zij geen nieuwen minnaar, dan zinken ze tot publieke vrouw, overgeleverd aan de lusten van allerlei mannen, zóó lang tot ze niet meer in trek zijn. In vroeger tijden werden die vrouwen, als zij zoover gekomen waren, opgehangen of de kampong uitgejaagd.

Overspel komt veelvuldig voor; ook de meisjes, die een vasten minnaar hebben; staan voor andere mannen klaar. De vader zelf moedigt zijn dochter tot geslachtsgemeenschap met verschillende mannen aan. Zulke onzedelijkheid staat wel als schande te boek, doch niemand neemt er aanstoot aan, omdat iedereen zich eraan schuldig maakt.

Oudtijds werden de meisjes, die zich niet aan mannen wenschten te geven, als heksen beschouwd, en door de jongelingen opgehangen. 
Erfrecht. Het erfrecht bij de Mentaweiers is een ongeschreven adatrecht, dat niet overal op dezelfde wijze geïnterpreteerd wordt. Steeds echter wordt de vrouw bij de verdeeling van een erfenis ten achter gesteld bij den man.

Ten aanzien van het erfrecht staan echtelijke en niet-echtelijke kinderen met elkaar gelijk.

Bij de toepassing van het erfrecht dient men verschillende gevallen te onderscheiden, naargelang van den staat en het geslacht zoowel van de overledenen als van de erfgerechtigden. Het is mij niet mogen gelukken, betrouwbare gegevens te verzamelen omtrent de regels, die in elk afzonderlijk geval gevolgd worden. De eenige maal, dat ik verplicht was, in een erfeniskwestie uitspraak te doen, werden er hooge eischen gesteld aan mijn geduld. De breedsprakige betoogen van klagers en gedaagden namen schier geen einde. Geruimen tijd duurde het, eer ik van niet-belanghebbenden bij deze erfenis voldoende inlichtingen verkregen had, om volgens recht en billijkheid uitspraak te kunnen doen.

Bij gebrek aan meer gegevens zij hier slechts vermeld de normale loop van zaken, wanneer kinderen de erfenis hunner ouders hebben te verdeelen.

Het geringste gedeelte van de nalatenschap komt aan de dochters, en wel dat gedeelte, dat zich het meest voor vrouwen eigent, t. w. het kladiveld, het huis- en kookgerei, e. d. g. Het aandeel van de zoons bestaat uit het huis, de prauwen, het vischtuig, de wapens, de gereedschappen, den pisangtuin, den klappertuin, enz. Geweven stoffen, kralen, enz. worden in den regel gelijkelijk tusschen zoons en dochters verdeeld. Zijn er geen zoons, dan erven de mannelijke verwanten dit alles. Zijn er gehuwde dochters, dan hebben de schoonzoons geen recht op iets uit de nalatenschap (wel de dochters zelve); de schoonzoon behoort niet tot de mannelijke verwanten, die erfgerechtigd zijn bij ontstentenis van zoons. Wel kan de schoonvader bij zijn leven b.v. een gedeelte van zijn klapperaanplant aan zijn schoon vermaken, doch de erfgerechtigde mannelijke verwanten moeten daartoe hunne toestemming geven.

Juist de verdeeling van den klapperaanplant geeft dikwijls aanleiding tot oneenigheden. omdat de welstand van den Mentaweier wordt afgemeten naar het aantal zijner klapperboomen. Die oneenigheden zijn oorzaak van langdurige veeten, 
want in deze materie kent de Mentaweier geen rechterlijke uitspraak (van den rimata b.v.). Een enkele maal trekt hij de stoute schoenen aan, en brengt hij de zaak voor bij ons bestuur.

Wanneer een kind te jong van jaren is om zijn erfdeel te aanvaarden, dan wordt dit voorloopig beheerd door zijn grootouders, of, bij ontstentenis van die, door andere verwanten. De beheerders genieten dan het vruchtgebruik van dat erfdeel.

Rechtspraak. In een vrijwel ongeordende maatschappij als de Mentaweische kan van een vaste regeling omtrent de rechtspraak kwalijk gesproken worden. Bepaalde rechters of rechtsprekende lichamen hebben nooit bestaan. Men was van ouds zijn eigen rechter en deed recht naar oogenblikkelijke inzichten of wel naar gebruiken of antecedenten.

$\mathrm{Nu}$ het volk onder geregeld bestuur is gebracht, is het uit met het zelfberechten van zaken. De magistraat heeft echter te bedenken, dat het volk nog niet rijp is om berecht te worden volgens het wetboek van strafrecht zooals elders. Geringe diefstallen b.v. te straffen met gevangenisstraf, zou niet beleidvol zijn, want hoewel het volk over het algemeen eerlijk is, beschouwt het diefstal niet als een zwaar misdrijf.

Wellicht komt het nu en dan nog voor, dat de Mentaweier zichzelf recht verschaft in onbeduidende zaken, maar over het algemeen brengt hij zijne geschillen voor bij ons bestuur. En vermakelijk is het, soms een aanklager te hooren beweren, dat hij kennis komt geven van een geschil, doch niet met de bedoeling dat de aangeklaagde gestraft zal worden!

Doodslag werd vroeger, ingevolge de bestaande bloedwraak, met den dood gestraft. Overigens werd de doodstraf slechts toegepast op heksen, die opgehangen of doodgemarteld werden.

Bij echtbreuk had de bedrogen echtgenoot het recht, zijne vrouw of haren belager te dooden. Meestal echter volstond hij ermede, zijne vrouw te verstooten.

Diefstal werd berecht door den dief ook wat af te nemen, of ook wel werd deze door den bestolene afgerost. Maakte een dief het te bont, door herhaalde diefstallen te plegen, dan werd hij de kampong uitgejaagd.

Bij een heksenproces stond veelal hebzucht op den voorgrond; vermogende personen (n.l. die een grooten klapperaanplant bezaten) werden dikwijls opzettelijk als heksen beschouwd, opdat 
men zich na hunne terechtstelling van hunne bezittingen zou kunnen meester maken.

De "criminaliteit» uit zich heden ten dage meestentijds in het niet of niet behoorlijk nakomen van gegeven bestuursbevelen, welke tekortkoming, wanneer zij niet van al te ernstigen aard is, gewoonlijk wordt gestraft met boete of met tewerkstelling, hetzij op de bestuurshoofdplaats van het eigen ressort, hetzij te Siberoet. Bij recidive of bij het plegen van zware vergrijpen ondergaan de Mentaweiers gevangenisstraf te Padang of worden zij als bannelingen naar andere plaatsen gezonden. Het ondergaan van straf, ver van huis, van familie en van kamponggenooten, vindt de Mentaweier een der grootste rampen, die hem kunnen treffen.

Eed. In den loop van een proces komen natuurlijk meermalen tegenstrijdige verklaringen voor. Men krijgt dan meestal een goede oplossing, door de betrokken personen hunne verklaringen te doen herhalen in tegenwoordigheid van het kamponghoofd, den rimata en eenige ouden van dagen hunner kampong. In den regel komt dan de waarheid voor den dag. Blijven de verklaringen desondanks tegenstrijdig, dan dient de eed geëischt te worden. De Mentaweische eed bestaat hieruit, dat de eedaflegger een stuk hout of bamboe neemt, en dit met zijn kapmes aan splinters slaat. Bij elken houw verklaart hij, dat de geesten hem mogen vermorzelen gelijk hij dit stuk hout doet, en hem allerlei straffen mogen brengen, indien hij onwaarheid spreekt.

\section{HOOFDSTUK VII.}

\section{Onderwijs en Zending.}

Eerst in den loop van het laatste tiental jaren heeft het Mentaweische volk kennis gemaakt met onderwijs en wel nadat de zending zich gevestigd had op de Pageh-eilanden. De zendelingen hebben een school opgericht op het zendingstation te Nemnemleleoe. Bovendien hebben enkele kampongs een eigen school, eveneens door zendelingen opgericht. Het onderwijs wordt gegeven, behalve door de zendelingen zelf, door Bataksche christen-onderwijzers. 
De scholen worden uitsluitend bezocht door jongens. Het onderwijs, dat in de Mentaweische taal wordt gegeven, omvat de volgende leervakken: lezen, schrijven, rekenen, zingen, aardrijkskunde, Maleische taal en godsdienstonderricht. De scholen hebben bewezen, dat "jong Mentawei» niet onbevattelijk is Kleine dreumessen kunnen soms reeds vlot lezen en netjes schrijven. En wie het krijschend en valsch gezang van kinderen op andere inlandsche scholen gehoord heeft, dien valt het hier op, hoe maatvast en vrij zuiver de kinderen zingen.

Wanneer de jonge Mentaweier de school doorloopen heeft, dan gaat, jammer genoeg, zijne opgedane kennis weer verloren, doordat het geleerde niet wordt onderhouden.

Deze te betreuren toestand zal blijven bestaan, zoolang de Mentaweier zich niet een werkkring zoekt, waarin hij het geleerde kan toepassen. Zoo'n werkkring zou hij voorloopig slechts kunnen krijgen op een der bestuurshoofdplaatsen, of nog verder van huis: op Sumatra. Doch eer hij ertoe te bewegen is, zoover weg te gaan, en dat enkel, om een werkzaam leven te leiden, zal hij zijne heidensche gebruiken en zijne indolentie ter zijde gezet moeten hebben.

Aan de straat Sikakap, een paar kilometer bewesten Sawang Toengkoe, bevindt zich het zoo even reeds genoemde Nemnemleleoe, het établissement van het Rijnsche zendinggenootschap, alwaar twee zendelingen wonen. Deze mannen, die familie, haardstede en beschaafde maatschappij vaarwel gezegd hebben, om God's woord onder de heidenen te verkondigen, leiden daar een sober, eenzaam bestaan, dat ieder ander weinig benijdenswaard voorkomt. Doch $z i j$ prijzen zich gelukkig, hun arbeid te mogen verrichten, en zij werken met opgewektheid en met onverdroten ijver.

Slechts hij, die kennis heeft gemaakt met de heidensche gebruiken, het vastgewortelde bijgeloof en het conservatisme van den Mentaweier, kan beseffen, welke reuzentaak daar voor de zending is weggelegd.

Neemt men in aanmerking, dat de zendelingen dagreizen ver van kampong tot kampong trekken, te voet of per prauw ',

1 De Mentaweische prauw is voor den Europeaan een afschuwelijk vervoermiddel. Men is gedoemd om uren lang in dezelfde houding te zitten, heeft dikwijls zelfs geen gelegenheid, de opgetrokken knieën eens uit te strekken, en is blootgesteld aan weer en wind. Het weldadige gevoel, dat men heeft, wanneer men na een roeitocht van soms 6 à 8 uren, op den vasten wal de beenen kan verzetten, laat zich beter denken dan beschrijven. 
en voegt men daarbij het niet zeer gezonde klimaat, dan komt men tot de gevolgtrekking, dat aan hun physiek geen geringe eischen gesteld worden.

Geen ontbering is den zendeling te groot, geen afstand is hem te ver, wanneer hij den Mentaweier met raad en daad kan helpen. Gaarne ziet men hem komen, den "toewan pendita», den raadgever, den medicijnmeester, wanneer zijne diensten noodig zijn. Doch men meene niet, dat die arbeid op prijs gesteld wordt; de Mentaweier is nu eenmaal niet dankbaar van nature! Maar de zendeling streeft naar geen dank, en helpt gaarne opnieuw, waar hij met ondank werd beloond.

Als de Mentaweier des Zaterdags, bij het vallen van den avond, van het zendingstation het bescheiden klokje hoort beieren, dan weet hij, dat de week ten einde spoedt. Dan weet hij, dat "toewan pendita hem den volgenden morgen verwacht in het lokaaltje, waar het woord verkondigd wordt van den God, dien de blanke man vereert. Sommigen, velen soms, maken zich des Zondagmorgens op naar het kerklokaal, deels uit vriendschap voor de zendelingen, deels uit belangstelling voor- of nieuwsgierigheid naar hetgeen gesproken zal worden. Uit overtuiging echter gaat niemand.

In hunne pogingen, om den Mentaweier tot den waren God te bekeeren, hebben de zendelingen tot nu toe geen dadelijk succès gehad. $\mathrm{Na}$ cen tiental jaren hebben zij het zóóver gebracht, dat het tot den Mentaweier is doorgedrongen, met welk doel zij gekomen zijn, en wat de Christelijke leer wil. Zijn heidendom vaarwel zeggen, deed de Mentaweier echter niet. Wel zijn er enkelen onder hen, die geneigd zouden zijn, het Christendom te omhelzen, doch die vreezen de minachting, de wraak der anderen.

Nog tal van jaren zal het duren, eer de zending den Mentaweier tot christen gemaakt heeft. Eerst dan, als hij van zijn heidensche gebruiken heeft afscheid genomen, kan er een bruikbaar mensch uit hem groeien. Dan zal hij zich kunnen ontpoppen als handelsman, als werkman, als ambachtsman, en zal hij zich het genoten onderwijs ten nutte kunnen maken. 


\section{INHOUD.}

Hoofdstuk I. Geografie; klimaat; bodemgesteldheid; fauna, flora en pomona . . . . . . . . 114

» II. Administratieve indeeling; bestuur . . . 128

» III. Bevolking; heerendiensten, passenstelsel ; belasting; geschiedenis; taal, literatuur; kleeding; tatouage; wapens; wijze van oorlogvoeren; werktuigen en gereedschappen; huizenbouw ; huisdieren . . . . . . 133

» IV. Godsdienst; bijgeloof; pantang; poenèn ; verbodsbepalingen; zedelijkheid; afgestorvenen; opvatting van natuur en natuurkrachten, geneeskunde, volkskarakter en volkseigenschappen; sagen en overleveringen . . . . . . . . . . . . . 169

V. Middelen van bestaan; cultures; landbouw ; veeteelt; jacht; visscherij; voortbrenselen ; handel ; nijverheid ; scheepvaart ; voedingsmiddelen

VI. Stamleven; huwelijk; geboorte ; echtscheiding; rechtspraak; eed . . . . 209

VII. Onderwijs en zending . . . . . . . 217 


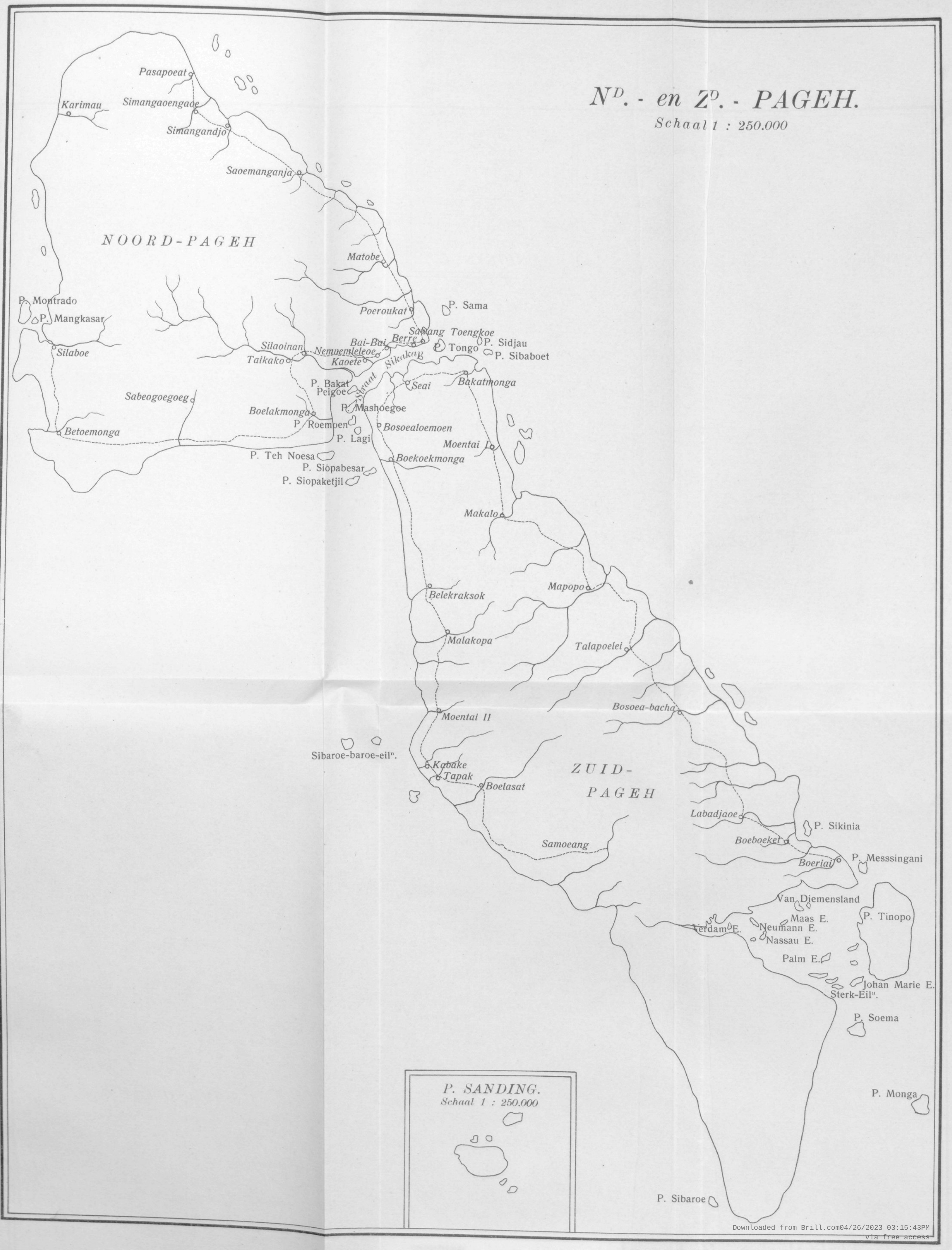

